NBER WORKING PAPER SERIES

\author{
WHY DON'T ISSUERS CHOOSE IPO AUCTIONS? THE COMPLEXITY OF INDIRECT \\ MECHANISMS \\ Ravi Jagannathan \\ Andrei Jirnyi \\ Ann Sherman \\ Working Paper 16214 \\ http://www.nber.org/papers/w16214
}

\author{
NATIONAL BUREAU OF ECONOMIC RESEARCH \\ 1050 Massachusetts Avenue \\ Cambridge, MA 02138 \\ July 2010
}

We thank Reena Aggarwal, Larry Ausubel, Robert Battalio, Lise Buyer, Harry DeAngelo, Ken French, Robert S. Hansen, Alexander Ljungqvist, Tim Loughran, Paul Milgrom, Ivan Png, Ed Prescott, Jay Ritter, Michael Sher, Sheridan Titman, and S. Viswanathan for useful comments; Rakesh Vohra for hepful discussions about auctions; Gjergji Cici, Huijing Fu, Jintana Kumeranakerd, Tim Lavelle, David Paredes, Mariya Todarova, and Andrew Y. C. Wong for research assistance; and M.J. van den Assem, Marc Goergen, Geeta Hemrajani, Richard Pettway, Jhinyoung Shin, John Wei and the many officials at various stock exchanges, regulatory agencies and research institutes for help in gathering the information used in this study (especially the Singapore Exchange, Istanbul Stock Exchange and Euronext). Some of the material in Table 2 circulated in an earlier working paper titled Global Trends in IPO Methods: Book Building vs. Auctions. Any inaccuracies or errors are, of course, entirely our own. The views expressed herein are those of the authors and do not necessarily reflect the views of the National Bureau of Economic Research.

NBER working papers are circulated for discussion and comment purposes. They have not been peerreviewed or been subject to the review by the NBER Board of Directors that accompanies official NBER publications.

(C) 2010 by Ravi Jagannathan, Andrei Jirnyi, and Ann Sherman. All rights reserved. Short sections of text, not to exceed two paragraphs, may be quoted without explicit permission provided that full credit, including $\left({ }^{C}\right.$ notice, is given to the source. 
Why Don't Issuers Choose IPO Auctions? The Complexity of Indirect Mechanisms

Ravi Jagannathan, Andrei Jirnyi, and Ann Sherman

NBER Working Paper No. 16214

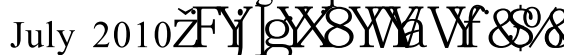

JEL No. D02,D44,G0,G12,G24,G3,H0,H10,H26,H29

\begin{abstract}
In this paper we present a comprehensive comparison of IPO placement methods in over 50 countries. We find that out of the three primary methods, fixed price public offers, auctions, and book building, auctions are least popular with issuers. Since auctions allow for price discovery while avoiding the potential conflict of interest between issuer and underwriter, this is a surprising finding that is not adequately explained in the existing literature. We propose a new explanation: namely, that participating in auctions is substantially more difficult for investors compared to the other methods, and that this complexity can lead to investor behavior that is undesirable for the issuer. We suggest that this effect could be mitigated through a hybrid mechanism that resembles the one that is used in US treasury auctions.
\end{abstract}

Ravi Jagannathan

Kellogg Graduate School of Management

Northwestern University

2001 Sheridan Road

Leverone/Anderson Complex

Evanston, IL 60208-2001

and NBER

rjaganna@northwestern.edu

Andrei Jirnyi

Northwestern University

2001 Sheridan Rd

Finance Dept. Rm 401

Evanston, IL 60208

a-jirnyi@northwestern.edu

\author{
Ann Sherman \\ Department of Finance \\ DePaul University \\ 1 E. Jackson Blvd., Suite 6100 \\ Chicago, IL 60604 \\ ann.sherman@depaul.edu
}




\title{
Why Don't Issuers Choose IPO Auctions? The Complexity of Indirect Mechanisms
}

\author{
Ravi Jagannathan ${ }^{\mathrm{a}, \mathrm{b}}$, Andrei Jirnyi ${ }^{\mathrm{a}}$, Ann Sherman ${ }^{\mathrm{c}}$ \\ ${ }^{a}$ Northwestern University \\ ${ }^{b}$ National Bureau for Economic Research \\ ${ }^{c}$ DePaul University
}

\begin{abstract}
In this paper we present a comprehensive comparison of IPO placement methods in over 50 countries. We find that out of the three primary methods, fixed price public offers, auctions, and book building, auctions are least popular with issuers. Since auctions allow for price discovery while avoiding the potential conflict of interest between issuer and underwriter, this is a surprising finding that is not adequately explained in the existing literature. We propose a new explanation: namely, that participating in auctions is substantially more difficult for investors compared to the other methods, and that this complexity can lead to investor behavior that is undesirable for the issuer. We suggest that this effect could be mitigated through a hybrid mechanism that resembles the one that is used in US treasury auctions.
\end{abstract}

Keywords: Initial Public Offerings, IPO, Auctions, Book building, Mechanism Design, IPO Auctions

\section{Introduction}

Bringing an initial public offering (IPO) to market requires a process that would determine who would be the initial investors ${ }^{1}$, how many shares each of them would obtain, and what price they would pay. The possibilities include book building, fixed price public offers, and auctions, as well as their various hybrids ${ }^{2}$.

In the United States, the primary method is book building, which gives the underwriter substantial discretion over allocations. However, when agents are given discretion, there is always the potential for abuse, and the numerous scandals following the internet bubble suggest that such abuses have occurred in practice ${ }^{3}$.

In comparison, sealed bid auctions are relatively more transparent, giving little discretion to the auction administrator, and are consequently less subject to manipulation and abuse. Moreover, the auction method is old and well established, and has been particularly successful for US Treasury securities and other government debt instruments. Not surprisingly, it is often suggested that auctions are a superior method of IPO placement ${ }^{4}$. Nevertheless, to this day

\footnotetext{
${ }^{2}$ We thank Reena Aggarwal, Larry Ausubel, Robert Battalio, Lise Buyer, Harry DeAngelo, Ken French, Robert S. Hansen, Alexander Ljungqvist, Tim Loughran, Paul Milgrom, Ivan Png, Ed Prescott, Jay Ritter, Michael Sher, Sheridan Titman, and S. Viswanathan for useful comments; Rakesh Vohra for hepful discussions about auctions; Gjergji Cici, Huijing Fu, Jintana Kumeranakerd, Tim Lavelle, David Paredes, Mariya Todarova, and Andrew Y. C. Wong for research assistance; and M.J. van den Assem, Marc Goergen, Geeta Hemrajani, Richard Pettway, Jhinyoung Shin, John Wei and the many officials at various stock exchanges, regulatory agencies and research institutes for help in gathering the information used in this study (especially the Singapore Exchange, Istanbul Stock Exchange and Euronext). Some of the material in Table 2 circulated in an earlier working paper titled Global Trends in IPO Methods: Book Building vs. Auctions. Any inaccuracies or errors are, of course, entirely our own.

${ }^{1}$ Ritter (2013) argues that there are alternatives available to firms that may be more attractive than going public.

${ }^{2}$ We describe each method, and the primary differences between them, in more detail below in 2.1

${ }^{3}$ Ritter (Forthcoming) discusses the CLAS controversies: Commissions for IPOs, Laddering, Analyst conflicts of interest and Spinning. See also Loughran and Ritter (2004) for discussion of the scandals and overall trends in IPO underwriting, and Ritter and Welch (2002), Ljungqvist (2007), Wilhelm (2005) for reviews of the academic IPO literature.

${ }^{4}$ Examples include "IPO Market Comes Back to Life", by Rachel Emma Silverman. Wall Street Journal, New York, N.Y.:Nov 11, 2003. pg. D.1. "Dutch auction IPO scheme grabs insider interest", The Red Herring (www.redherring.com), October 30, 2003. "BofI Holding Has Textbook Auction IPO", 15 March 2005, Dow Jones News Service. In fact, some have even argued that U.S. issuers should be forced to use auctions (see for
} 
the vast majority of US IPOs have followed the book building scheme, and book building has become the dominant method internationally, as we will show.

In order to explain this phenomenon, a number of explanations have been proposed in the the academic literature. For example, Sherman and Titman (2002) and Sherman (2005) argue that the greater control and flexibility of the book building method and the discretion that comes with it, under certain conditions, provide substantial benefits for the issuers who are interested in choosing a particular level of underpricing to induce the desired amount of information gathering and price discovery by potential investors ${ }^{5}$. However, given the great variety of IPOs, it seems plausible that such conditions would be less than universally prevalent - e.g. one may expect that information production considerations would be less important in cases when rewarding price discovery is particularly costly. Thus, the low popularity of auctions in the US is somewhat of a puzzle. Unfortunately, the rarity of the US IPO auctions makes this puzzle difficult to investigate. In addition, it is unclear if the US situation is a result of some unique local circumstances, or is prevalent across markets.

In this paper we provide a comparative review of international IPO practices, and the factors that influence the choice of the IPO mechanism from the three most common types of IPOs. In Section 2 we offer evidence on overall usage patterns - first listing the many countries that have tried and abandoned the auction method, and then examining IPO auction outcomes in more detail. We find that, when standard auctions have had to compete with another method - either with fixed price public offers or with book building - auctions have lost out. Of the 50 countries that we examine, more than half have used the auction method at some point, yet IPO auctions are still in use only in the US, where usage has been sporadic and relatively rare, and in Vietnam, India and Israel, where there are (or until recently have been) restrictions preventing the use of book building.

In Section 3 we argue that issuers' preferences for price discovery are not sufficient to explain this apparent lack of popularity of auctions. We also present empirical evidence suggesting that it is not explained either by the lack of familiarity among investors, or by differences in underwriting fees. For example, auctions have initially been quite popular in many countries, and the fees for fixed price public offers in most of them have been the same as those for auctions, leaving investment banks with no incentive to favor one method over the other based on fees. In spite of that, when issuers have been allowed to choose between fixed price public offers and auctions, the former method generally prevailed. The fixed price public offer method in turn lost market share when it faced competition from book building. Our findings refute the view that, but for the investment banks' market power, standard auctions would have replaced the book building method for bringing new equity issues to the market.

Our explanation for the popularity of the book building method relies on the observation that each underwriter of an IPO has a network of regular investors. Because of the long-term enduring nature of the underwriter-regular investor relationship ${ }^{6}$, the underwriter is able to provide the necessary incentives to all investors participating in the book building process to truthfully reveal their views regarding what they think the issue is worth to them and how many shares they are willing to buy at various possible offering prices. Therefore book building can be thought of as being closer to a "direct" mechanism ${ }^{7}$ that requires little sophistication on the part of participants. In contrast, bidding in IPO auctions requires a high degree of sophistication on the part of all the participating investors. In addition to valuing the shares being issued, each bidder must assess how many other bidders there will be, how much information they have, and what bidding strategies they will use, while at the same time accounting for the mistakes those other bidders may be potentially making - and all that makes bidding in an IPO auction a demanding task ${ }^{8}$. Much of the theoretical literature ignores how investors actually make decisions. In particular, they ignore the heterogeneity in investors' levels of sophistication and ability to analyze IPO firms' prospects, and hence their ability to participate in various mechanisms. When this heterogeneity is taken into account, it becomes apparent that standard sealed bid uniform-price auctions can be risky for both investors as well as issuing firms. We discuss these issues in Section 4.

\footnotetext{
example, "The Value of Trust," Economist Staff, The Economist, June 07, 2002.) The U.S. Securities and Exchange Commission asked for public comments on whether issuers should be forced to use auctions, since few have so far been willing to use them voluntarily. Forced action usage has been tried in, for example, Japan, Israel, and Vietnam.

${ }^{5}$ See also Benveniste and Spindt (1989) and Benveniste and Wilhelm (1990)

${ }^{6}$ See Sherman (2000) for a discussion of how long-term relationships with investors helps the underwriter to offer the issue at a higher price on average by favoring regular uninformed investors in allocations.

${ }^{7}$ Note that our use of the term "direct" is nonstandard

${ }^{8}$ Nonequilibrium bidding, and its effects such as a persistent winner's curse, has received high-profile attention in recent auctions research, e.g. Eyster and Rabin (2005) and Crawford and Iriberri (2007)
} 
In Section 5 we show how these issues played a role in the failure of some IPO auctions. We provide additional anecdotal evidence for the lack of popularity of IPO auctions, and investigate in greater detail IPO auctions in Singapore. We also discuss the differences between IPO auctions and auctions for Treasury bonds and why the latter have been successful. We believe that the evidence we present makes the lack of popularity of IPO auctions less of a puzzle. We conclude in Section 6.

\section{Global Patterns and the Surprising Rarity of IPO Auctions}

When Margaret Thatcher, Prime Minister of the UK, began privatizing British companies in the early 1980s, she set off major changes around the world in government, in industries and in IPO methods. Before then, the IPO method in most countries outside the US was fixed price public offer (a.k.a. open offer, universal offer or often simply called "the IPO method"). The trend towards floating extremely large public companies forced countries to try new methods and to coordinate IPOs across borders, since many privatizations were too big to be absorbed entirely by the local market. The wave of privatizations led to experimentation first with auctions and then with the US book building method.

Before we proceed with our investigation of international IPO experience, we will first describe the existing methods and their defining features.

\subsection{IPO Mechanisms: Fixed Price Public Offers, Book Building, and Auctions}

In fixed price public offers, the price and allocation rules are set before information on demand is received, and shares are allocated according to the rules announced earlier. This method may offer some flexibility in allocating shares across groups (for example, favoring small orders over large orders, as is done in many countries), but we do not classify offerings as being fixed price public offers unless the underwriters and issuers have little or no discretion in terms of share allocations.

With book building, the underwriter typically arranges for investors to attend a road show and then collects indications of interest, which are used to build the order book. The offer price is set only after the order book is full, giving the underwriter some idea of demand, and the issue size may also be adjusted based on demand. In the definitions we used to categorize offers, the key distinguishing feature of book building is that the underwriter has substantial discretion over allocations and pricing.

Auctions for IPOs have taken several forms. Uniform price auctions are multi-unit sealed bid auctions in which all winning bidders pay the same price. The price paid may be the market-clearing price (the highest price that allows all shares to be sold), or it may be below the clearing price, leading to increased rationing. A "dirty" IPO auction was traditionally defined as a uniform price auction where they "leave something on the table" by pricing below marketclearing, and this is how we use the term in this paper, although some people now use the term a dirty auction to also incorporate practices such as giving some bidders information about the bids of others during the bidding period, as has been done in some U.S. IPO auctions ${ }^{9}$. In a discriminatory or pay-what-you-bid auction, each winning bidder pays his or her own bid. While some auctions restrict entry, historically most IPO auctions have been of an open public nature. The auction price is based on investor bids, but unlike book building, auction allocations are usually determined by rules that are set, and publicly announced, prior to bidding, thus eliminating underwriter discretion with respect to allocations.

With either fixed price public offers or sealed bid auctions, underwriters may, and sometimes do, hold road shows before the offer price is set. As in book building, they are allowed to ask for feedback that may influence the offering price in the case of the fixed price public offer or the reservation price in the case of auctions. However, without control over allocations, underwriters may not be able to offer enough of an incentive for investors to produce and share information.

Many countries have used hybrids - combinations of any two of the three methods. There have been hybrid auction/public offer and auction/book building IPOs, but the most common combination is book building/public offer. For most hybrids, book building (or sometimes an auction) is used to set the price and to allocate shares to institutional

\footnotetext{
${ }^{9}$ Biais and Faugeron-Crouzet (2002) show that pricing below market-clearing can encourage the revelation of endowed information from bidders.
} 
and foreign investors, while a fixed price public offer tranche is reserved for local retail investors that do not participate in the price-setting process. There are two types of hybrids: simultaneous and sequential. With sequential hybrids, the price-setting tranche is completed first, so that the price from that tranche can be used for the subsequent fixed price public offer. Simultaneous hybrids are often called 'open pricing', since investors have to place orders while the offer price is still 'open' (before the final price is set). This allows both tranches to run at the same time, thus allowing the offer price to be set as late as possible.

As mentioned earlier, we will refer to commonly used uniform-price and discriminatory auctions as indirect mechanisms, where every participant will have to factor in what other participants know and how they will bid before submitting their own bids. In contrast, in direct mechanisms the incentives are such that all bidders report their valuations truthfully to the auctioneer (underwriter). Book building may come closer to a direct mechanism, with bidders privately communicating their valuations to the underwriter, and the underwriter setting prices and allocations in a way that provides them with sufficient incentives to report.

It is well known that for a large set of mechanisms, the Revelation Principle (Myerson, 1981) states that for any indirect mechanism, there exists a direct one that generates identical outcomes in model economies. However, outcomes of theoretically equivalent direct and indirect mechanisms often differ in laboratory experiments ${ }^{10}$. Whether this is an important enough issue in the case of IPOs can only be discerned based on the historical experience of countries that have experimented with several different mechanisms for IPOs.

\subsection{International Historical Evidence}

We conduct an extensive study of IPO placement practices in 50 countries. Unfortunately there is no standard reliable source of international data on IPO placement methods ${ }^{11}$. Table 1 summarizes the IPO methods used in each country, with more detailed information given in Table C.1. As one can see in these tables, most countries allow the use of many methods. We do not know of any country that had formerly allowed auctions and then changed their regulations to prohibit or limit them, or of any country that has forced issuers to use book building - the general trend in the last two decades has been to allow greater choice among issuers.

There are two notable patterns. First, the book building method was once rare outside the US but is now common. Second, auctions have been tried in more than 25 countries but are rare today.

Table 1 shows that the traditional method (in other words, the first and for many years the only method) in most countries is fixed price public offer. It also shows that nearly all countries except the United States are still using fixed price public offer in some form, either alone or as part of a book building hybrid. As a rough generalization, Table 1 shows that experimentation with auctions began in the 1980s or earlier in Europe, and in the 1990s or later in Asia and the Americas, but the auction method generally was dropped within a few years. Experimentation with book building exploded in the mid-1990s, and the method seems to have 'stuck' in most countries, again as a hybrid with fixed price public offer. Auctions usually were abandoned before book building was introduced, so that there have only been a few countries in which both methods were in use at the same time ${ }^{12}$.

Although auctions have been used in more than half of the 50 countries listed in Table 1, the method seems to have been entirely abandoned in all but three or four of them, and usage is rare even in those few remaining countries. As can be seen in Table C.1, auctions are used sporadically in the US, at a rate of less than 2 per year (22 from 1999 to 2012). They are the only method allowed in Vietnam, and a restricted type of auction is used in India, which prohibits book building. They have been frequently used in the past in Israel, where auctions were the only allowed method for a decade. Book building has been allowed in Israel since mid-2007, but the market has not been active since that regulatory change, so it is too early to tell how the choice of issue methods will evolve there.

In India, book building was first allowed in the 1990s but was not popular for many years. Eventually, after regulatory changes, book building became more popular there, but in 2005 the Indian regulator ${ }^{13}$ began mandating

\footnotetext{
${ }^{10}$ See e.g. Charness and Levin (2005).

${ }^{11}$ SDC Platinum offers the currently most extensive international IPO database. It includes indicators of placement and pricing techniques, but unfortunately these are missing for a large part of the dataset, and worse, are rather unreliable in terms of describing the actual process: e.g. auctions in Taiwan, Singapore and France are inconsistently classified as either fixed price or book building; on the other hand, many book built issues in US and UK are classified as fixed price, etc.

${ }^{12} \mathrm{~A}$ useful source for the number of IPOs, over varying time periods, in 49 countries can be found on Jay Ritter's website, http://bear.warrington.ufl.edu/ritter/ipodata.htm. Among other IPO data, this website provides an update of Table 1 from Loughran et al. (1994).

${ }^{13}$ see SEBI Circular \#SEBI/CFD/DIL/DIP/16/2005/19/9
} 
Table 1: Summary of IPO Methods Used in Various Countries.

A blank in any column means that, to the best of our knowledge, the method was not used. The "first introduced" years are the earliest years that we were able to find but may be later than the actual year of first use. On whether the book building method is now dominant or gaining in popularity, the answer is in the judgment of the main source listed in Table $\mathrm{C} 1$, or our best estimate if no other source was available. News article sources for any country are available upon request.

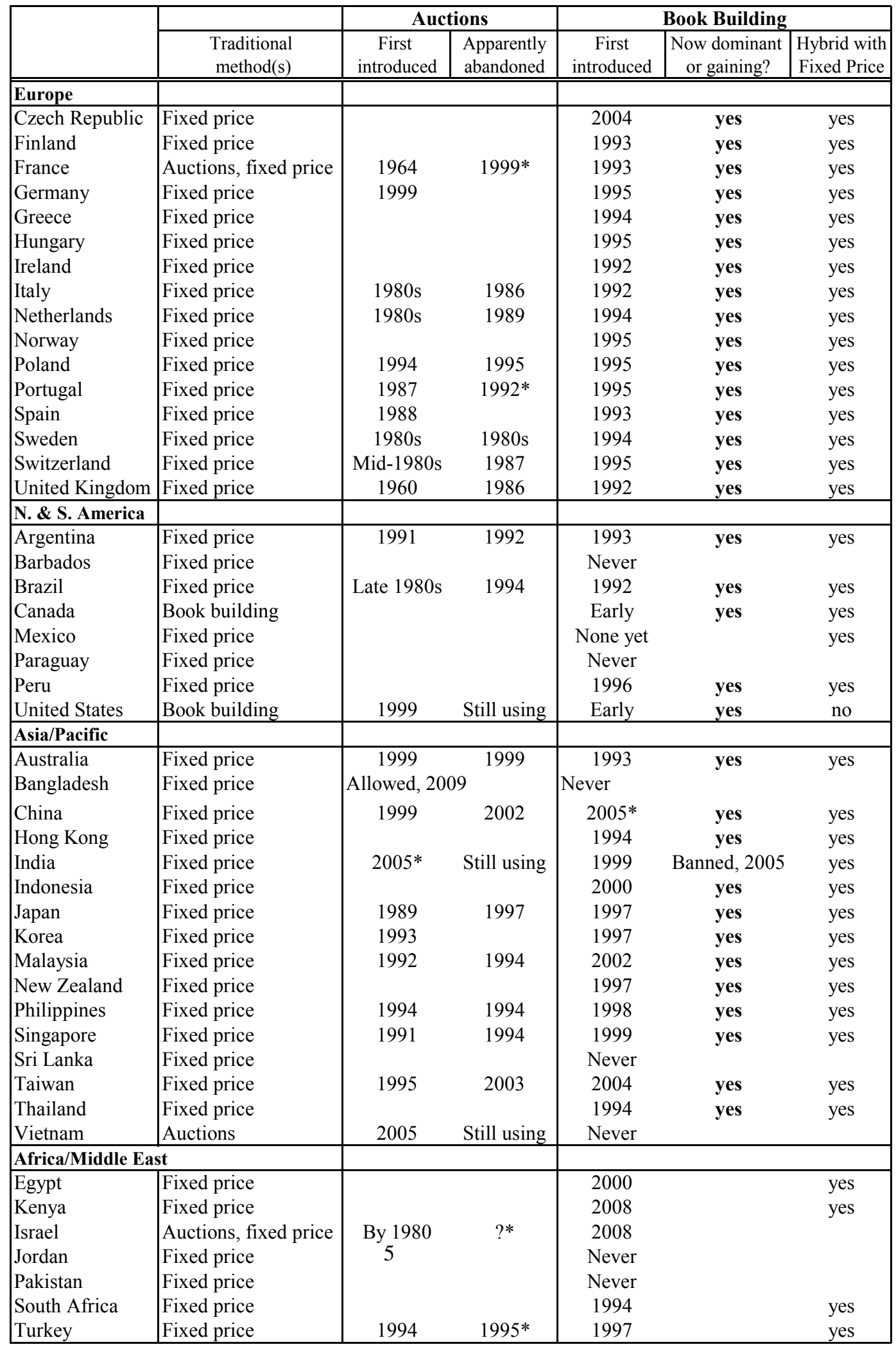

*Some unusual features or exceptions. See Table C.1 for more detail. 
pro-rata allocation among bidders, thus effectively banning book building. In Indian IPOs, the issue manager sets a price band for the issue, and investors have to submit bids with prices falling within that price band. Interestingly, in $76 \%$ of the 309 Indian IPOs during the period January 2000 to December 2010 that used the book building method, the offer prices were set at the maximum of the price range. In $13 \%$ of the IPOs the offer prices were at the floor, and the rest had the offer prices at the mid point. Indian IPOs therefore resemble a modified version of a fixed price public offer rather than book building or a uniform price auction ${ }^{14}$.

Auctions are being used in Vietnam, but issuers there are allowed no choice of methods. Vietnam is still developing its markets in its transition away from central planning, and most IPOs are privatizations.

In France, auctions were popular in the first half of the 1990s. On the regulated exchanges, they gradually lost market share to sequential hybrid book building over several years, then dried up quickly in 1999 when simultaneous hybrid book building was allowed. Auctions continued to be used on the unregulated over-the-counter market (the Marche Libre or Free Market) for several more years, although they eventually seem to have dried up there, also. There were, however, two IPO auctions in France in early $2005^{15}$, which came after there had been no auctions on regulated French exchanges for half a decade.

Auctions were the only method allowed in Israel for a decade. The law requiring their use expired in December, 2003, after which issuers were allowed to effectively choose a fixed price public offer by setting a maximum price for the auction. Many of the IPOs between 2004 and mid-2007 chose to set a relatively low maximum price for their offerings, thus effectively choosing fixed price over auction ${ }^{16}$. In July 2007, a long-debated change went into effect, allowing book building for the first time. It is too soon at this point to tell how auctions will compete with book building in the Israeli market.

Auctions were the only method allowed in Japan from 1989 through 1997. Discriminatory (pay-what-you-bid) hybrids were required, with the fixed price public offer tranche paying the weighted average winning bid price from the auction. Due to perceived problems with auction overpricing, the rules were changed in 1992 to require more of the shares to be auctioned (at least 50\%) and to allow the fixed price public offer tranche to be priced strictly below the weighted average winning bid price from the auction. Maximum order size in the public offer tranche was limited, inducing institutional investors to participate primarily through the auction, and in some cases minimum bid sizes were used in the auctions to try to discourage small bidders from participating. When issuers were allowed to choose between auctions and book building beginning in 1997, auctions vanished within one quarter ${ }^{17}$.

Since 1995, Taiwan has allowed both auctions and book building, in addition to the traditional fixed price public offers. Taiwan's auctions are similar to those that were originally required in Japan - discriminatory hybrids. Auctions were initially popular but lost market share over time, with more and more issuers returning to pure fixed price public offers. Book building was originally allowed only in certain restrictive circumstances but has gained popularity in the last few years.

In Latin America, auctions have been used in Argentina, Brazil and Peru in the past. Latin American markets were quiet for many years, with delistings outnumbering listings in Brazil, Argentina and Chile ${ }^{18}$. Thus it was hard to predict if auctions were gone completely. However, Brazilian, Chilean and later Argentinean IPO markets began picking up in 2004-2005, with even stronger activity in 2006, and book building has been the dominant method, with no auctions that we know of over the last decade.

In the US, the investment bank WR Hambrecht has been encouraging issuers to use auctions since mid-1999. The method got much publicity when Google, a popular search engine company, chose to use the auction method

\footnotetext{
${ }^{14}$ Private communication from Amit Bubna

${ }^{15}$ The two 2005 auctions were for Cafom, on the Second Marche in January and for MG International, on Alternext in June. There have been no further auctions in France as of late 2012.

${ }^{16}$ The law for one decade had forbidden the use of a maximum price. Technically, Israel was using auctions even before this, but it had become standard to set the maximum price so low that it was virtually sure to be hit, thus effectively making the method a fixed price method. In 2007 , Itamar Medical, Maayan Ventures, Clal Finance and Brainsway all set maximum prices for their IPOs, and all ended up being priced at those maximums, but we have not yet been able to verify what proportion of all TASE IPOs set maximum prices.

${ }^{17}$ Japan's IPO auctions included many large privatizations. The largest IPO auction that we know of was for Japan Tobacco, with proceeds (converted to US\$ but not adjusted for inflation) of \$5.8billion, while the second-largest that we know of, the 1994 IPO auction of Singapore Telecom, raised only $\$ 2.7$ billion. Japan Tobacco originally expected to raise $\$ 9.8$ billion, but the auction tranche price was perceived to be so excessive that individuals withdrew their previously-placed orders for the fixed price public offer tranche, so that only $42 \%$ of the retail tranche shares were sold.

${ }^{18}$ For example, Chile had no IPOs at all from 1998 to 2001 and only one each in the years 2002 and 2003.
} 
for its August, 2004 IPO, but still the auction method is not popular in the US. As of 2012, there have been 22 US IPO auctions, 19 of them lead-underwritten by WR Hambrecht through its OpenIPO method. Of the other 3 US IPO auctions, the lead underwriters were: Credit Suisse and Morgan Stanley for Google in 2004; Credit Suisse for Netsuite in 2007; and Credit Suisse, Goldman Sachs and Merrill Lynch for Rackspace in 2008. US auctions have had some unusual features (see the "United States" column of Table C.1, p.41).

Several types of IPO auctions have been used. Brazil, Japan, Malaysia, the Philippines, Singapore, Taiwan and the UK have used discriminatory auctions, while Argentina, Australia, Brazil, Finland, France, India, Israel, Malaysia, the Netherlands, New Zealand, Norway, Peru, Portugal, Singapore, Turkey, the UK, the US and Vietnam have used uniform price auctions. "Dirty Dutch" (priced below market clearing) auctions have been used in Australia, Belgium, Finland, France, Hungary, India, Malaysia, New Zealand, Singapore, Turkey, the UK, and the US.

Thus out of 50 countries, auctions have been tried in at least half, and yet all except India, Israel, the US and Vietnam seem to have abandoned them entirely. Auctions are rare even in these last few countries, although the choice of non-auction methods is restricted in two of the four (India and Vietnam). Book building is gaining in popularity or is already the dominant method in more than 40 of the countries. Fixed price public offer is still used in smaller countries and for smaller offerings, and is used for the retail tranche of hybrids, which are standard.

The popularity of fixed price public offers in less active markets is to be expected if, as we conjecture, the reason for book building's dominance is that it is a "direct" mechanism. As we shall see below, implementing a mechanism such as book building requires an established, trusted and sophisticated underwriter, communicating with investors who have sufficient capacity to collect and process information. Lacking these conditions, the potential benefits of book building disappear and simple fixed price public offers become more attractive due to their simplicity: they rely much less on the reputation of the underwriter compared to book building, and require much less sophistication on the part of investors compared to auctions. Hybrids can be fine-tuned to specific requirements and are therefore observed in a wide range of markets.

\section{Rarity of IPO Auctions: Popular Explanations}

In what follows we discuss several commonly offered explanations for the lack of popularity of IPO auctions, and argue that they are not fully consistent with observed global evidence.

\subsection{Heterogeneity in issuing firms' objectives}

One of the explanations advanced in the literature for the popularity of the book building method is the flexibility it offers the issuing firm relative to auctions when it comes to the tradeoff between minimizing underpricing and promoting information gathering by investors. Indeed, there are several reasons to believe that issuers care about other aspects of the process beyond just the magnitude of underpricing as evidenced by initial returns. For example, one reason to go public is to give current stockholders such as the founders, venture capitalists and angel investors a chance to diversify by liquidating at least part of their holdings. Such investors usually cannot sell until the end of the lock up period and thus care about the eventual stock price as well as the offer price and first day's trading price. If a deep, liquid market is not established, those investors may be unable to sell their shares at a reasonable price, even after the time and expense of an IPO. Companies that go public but do not attract an institutional investor following may end up as "Orphans", not covered by analysts or otherwise monitored closely enough to be accurately priced. This means that they will be unable to do follow-on equity offerings and will tend to trade at a substantial discount, due to their illiquidity and added risk. In order to minimize this possibility, firms may be willing to pay, through underpricing, to attract the attention of serious investors in the IPO ${ }^{19}$. This may explain the importance of analyst coverage found in Loughran and Ritter (2004), Cliff and Denis (2004) and Mola et al. (Forthcoming). In the words

\footnotetext{
${ }^{19}$ Underpricing as a way of inducing costly evaluation has been modeled in Sherman (1992), Chemmanur (1993), Booth and Chua (1996), Sherman (2000), Sherman and Titman (2002) and Busaba and Chang (2003). Yung (2005) models costly evaluation by both investors and the underwriter. Cornelli and Goldreich (2001), Jenkinson and Jones (2004)) and Cornelli and Goldreich (2003) offer evidence on whether or not book building performs this role in practice. See Sherman and Titman (2002) for a list of additional reasons why issuers may prefer more accurate pricing.
} 
of Martin Manley, Chairman and CEO of Alibris ${ }^{20}$, "Taking a company public is like getting a heart transplant: you only do it once and you need it to be done very, very well. It is not a decision driven by price."

This brings up the question of what objective function issuers are maximizing when choosing an IPO method. Loughran and Ritter (2004); Sherman and Titman (2002); Sherman (2005), Chemmanur and Liu (2003) and Liu and Ritter (2011) offer alternative objective functions that consider more than just maximizing proceeds. The appropriate objective function for IPO issuers is a subject in itself, and one worthy of future research. In this paper, we simply note that the evidence indicates that issuers care about more than just maximizing the expected proceeds from the IPO.

Sherman (2005) compares open uniform-price and discriminatory auctions to the results of a mechanism-design approach in which the underwriter invites investors to participate and has discretion over both pricing and allocations. This optimal mechanism is termed "book building", because book building, from a regulatory standpoint, allows the issuer to chose price and allocations.

She considers the possibility that an issuer's utility may depend on both expected proceeds and pricing accuracy ${ }^{21}$, and shows that the ability to control allocations offers additional flexibility, allowing the underwriter to decide on the tradeoff between the two objectives. However, as Sherman (2005) demonstrates, auction outcomes can sometimes be close to those of the optimal mechanism, as we can see from her example in which issuers who place a high value on pricing accuracy can do well with a discriminatory auction ${ }^{22}$. The key disadvantage of the sealed bid auctions that Sherman models is largely due to the "open public" (i.e. every investor has the option to participate) setting, rather than of the auction method itself. A private ("by invitation only") auction would not have this disadvantage. Moreover, the comparison in Sherman (2005) does not account for the lack of transparency and resulting potential for abuse that occurs with book building, because of the agency problem between the issuer and underwriter. One of the few papers that has modeled this agency problem is Biais et al. (2002), for the French regulatory regime. Thus, at least under certain conditions, auctions may have an advantage over book building because of their transparency. Hence, it would be difficult to explain the extent to which book building has come to be the dominant IPO mechanism in practice based only on the reasons that have been advanced in the theoretical finance literature.

\subsection{Unwillingness to try a new method?}

Another possible explanation for the low numbers of IPO auctions in the US is that the auction method is simply too new and experimental, and that issuers are afraid to try an unproven method. This is plausible, since an IPO is a very expensive, very public step for a company, so issuers may not be anxious to experiment. However, this 'lack of familiarity' argument cannot explain the overall low market share of the auction method around the world. First, the mere fact that IPO auctions have been used in at least half the countries for which we have information implies that quite a few issuers have been willing to experiment. More importantly, if we look at relative usage patterns over time, issuers have been most enthusiastic about IPO auctions when the method was new, and they generally became less willing to use it after they had become more familiar with the method.

Figure 1 shows the relative auction usage patterns over time in four countries. For Singapore, Taiwan and Turkey, the main alternative method was fixed price public offers, which had been the traditional method in those countries. Auctions were first allowed in 1993 in Singapore ${ }^{23}$ and Turkey, and in 1995 in Taiwan. In France, both auctions and fixed price public offers had been used for decades, but sequential hybrid book building was first introduced in the 1990s, while standard book building was only allowed beginning in 1999.

As can be seen from Figure 1 for the three countries in which the open IPO auction method was newly introduced, auctions captured their greatest market share early on, with two-thirds or more of issuers choosing to use auctions when they were relatively new. As issuers became more familiar with the method over time, a lower proportion of them chose to use the auction method. Hence, it is hard to argue that, in these countries, the disappearance of IPO auctions was due to lack of familiarity or to an unwillingness of issuers to try a new method.

\footnotetext{
${ }^{20}$ Alibris held an IPO auction through WR Hambrecht in May, 2004, but canceled it after observing the bids. See Mr. Manley's blog, Jam Side Down, at http://www.martinmanley.com/ipo_diaries/.

${ }^{21}$ Defined in the paper as the probability that at least one investor receives an informative signal.

${ }^{22}$ See Sherman (2005), Table 1, p.633.

${ }^{23}$ The graph shows only uniform price auctions for Singapore. Singapore also had one discriminatory auction in 1991 and one in 1992. Uniform price auctions were first allowed in 1993.
} 
Figure 1: How Auctions Evolved over Time in Four Countries

In each graph, the X's (right axis; connected by dashed lines) give the number of total IPOs per year in that country, while the diamonds (left axis; connected by solid lines) are the percentages of IPO auctions out of all IPOs.

Sources: A: E-mail from the Stock Exchange of Singapore, October, 1999. B: The data was given to us by K.C. John Wei. See Liu et al. (2001) and, for 2002-2003 data, Hsu and Hung (2005). C: E-mail from the Istanbul Stock Exchange, March, 1999. D: Derrien and Womack (2003) and Chahine (2001). E: Euronext website (www.Euronext.com, in IPO Archives).
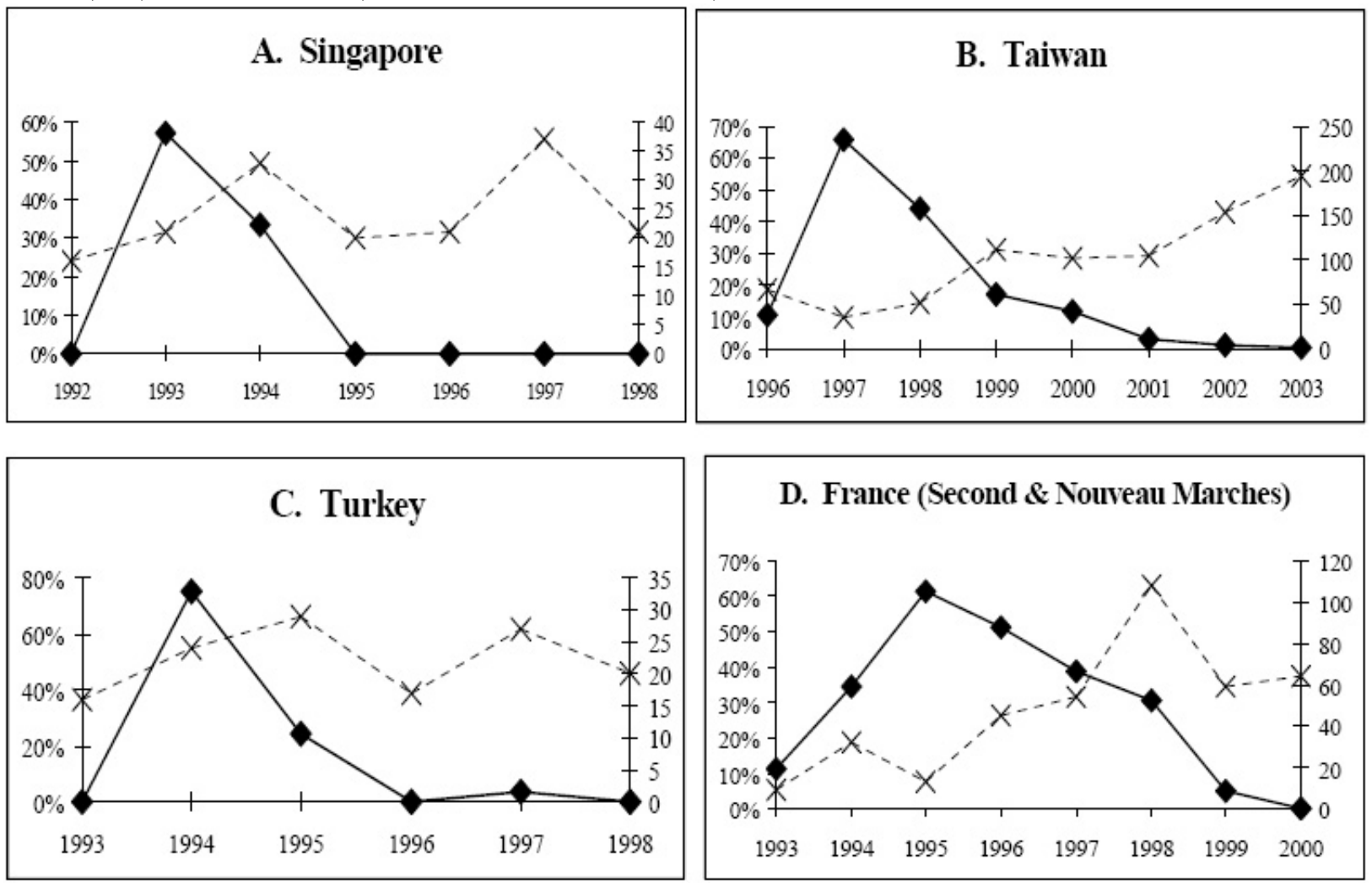

D. France (Second \& Nouveau Marches)

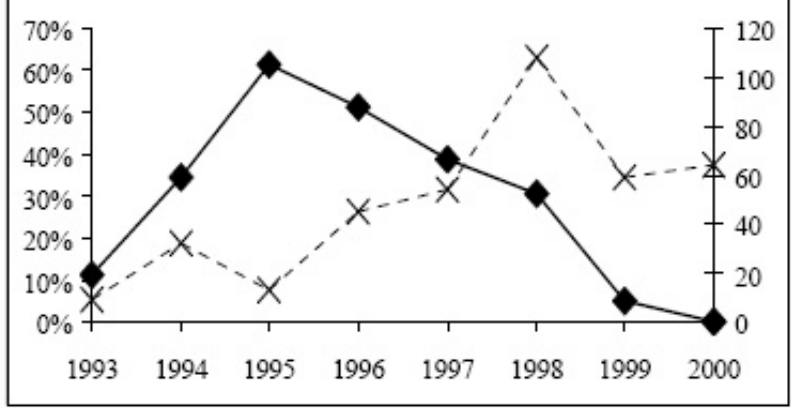

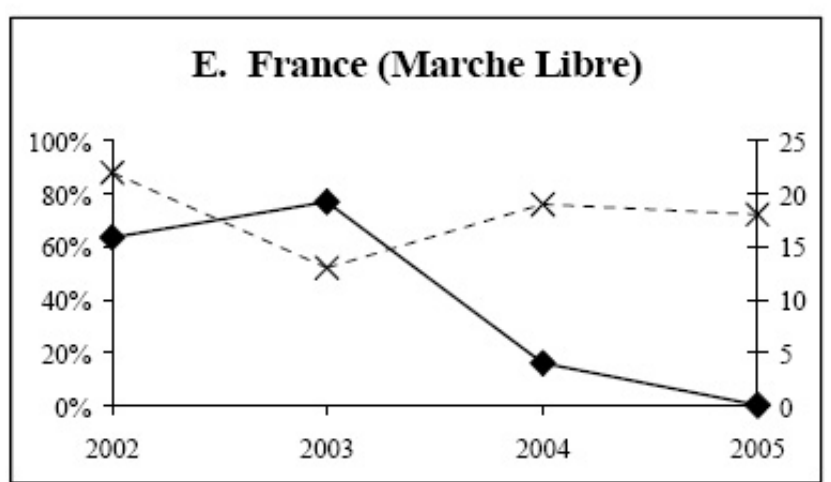


Of the four countries whose usage patterns are shown in Figure 1, France differs from the others in several ways. First, the auction method had been allowed for several decades in France. Second, a form of book building was in use during the period shown, in addition to auctions and fixed price. Last, the disappearance of auctions from the regulated exchanges seems to have been driven by a regulatory shift that allowed greater choice.

Derrien and Womack (2003) found that sequential hybrid book building was less efficient than auctions in France due to the requirement that the price be set too far in advance. Before 1999, the only form of hybrid book building that was allowed in France was a sequential hybrid, where the price must be set in advance to allow time for the public to place their orders. As the modeling in Chowdhry and Sherman (1996a) demonstrates, setting prices too early adds risk, leading to higher levels of underpricing. Once the more modern, simultaneous hybrid book building method was allowed in France in 1999, auctions quickly vanished from the regulated exchanges ${ }^{24}$. The 1999 regulatory change seems to explain the timing of auctions drying up on the French regulated exchanges, although it does not explain why they were still used for several more years on the unregulated over-the-counter Free Market (Marche Libré). Eventually, as shown in Figure 1 (Panel E), auctions also dried up on the Free Market.

One obvious question is whether issuers in these countries were truly allowed to choose freely between IPO methods. Although there were no regulatory restrictions that prevented issuers from using auctions, strong differences between the groups of issuers using different methods might imply some other sort of barrier, such as underwriter reluctance to underwrite auctions for some issuers. Therefore, in unreported analysis, we compare fixed price public offers and auctions in Singapore, Turkey and on the French Free Market based on both industry and amount of funds raised $^{25}$. We did not find substantial differences in the size or industry patterns of auction and non-auction issues.

Thus it is clear, in all four of the countries shown in Figure 1, that the disappearance of auctions was not due to issuers' lack of familiarity with the auction method. Similarly in Japan, issuers were forced to use auctions from 1989 to 1997. In spite of the long period during which IPOs in Japan were accomplished exclusively through auctions, the method was abandoned as soon as issuers were given the option of instead using book building.

There is not enough evidence to conclusively reject the 'lack of familiarity' argument for all countries. It may explain why auctions have not caught on in countries with limited usage, such as Germany, Australia or the US, or in countries that have never tried auctions at all. It may also explain why open public auctions for corporate debt and seasoned equity never caught on $^{26}$, even though there was a race between three investment banks to introduce online corporate bond auction platforms in $2000^{27}$, and WR Hambrecht offers an online seasoned equity auction method known as OpenFollowOn ${ }^{28}$. But the overall IPO evidence is that issuers in many countries have been willing to experiment with both auctions and book building, and that issuers became less likely to choose auctions as they gained familiarity with the method.

\subsection{Underwriter Pressure for Using the Book building Method}

Another explanation for the failure of issuers to use IPO auctions is that investment banks have sufficient market power to negotiate the use of book building rather than auctions because the fees, and hence profits, are higher for book building. This argument is somewhat incomplete. While market power can explain the high fees, it can not by itself explain the choice of the issuing method: if underwriters have sufficient market power to keep book building fees artificially high, and sufficient market power to influence the offering method chosen by the issuers, they would

\footnotetext{
${ }^{24}$ With the exception of the two IPO auctions in 2005 that were mentioned in Section I.

${ }^{25}$ Comparisons of French Second and Nouveau offerings can be found in Derrien and Womack (2003) and Degeorge, Derrien and Womack (2007). Hsu and Hung (2005) compare Taiwan IPOs by method.

${ }^{26}$ Bortolotti et al. (2006) show that auctions, in the form of block trades, have increased dramatically in the last decade and have become quite common around the world for seasoned equity offerings. The success of these SEO auctions fits well with our findings for IPOs, since the block trade auctions are single-unit auctions among a small group of sophisticated buyers - investment banks. The investment bank that wins the auction buys all of the shares at the winning bid price and then resells them on the market. With only one buyer, there is no room for free riders. Because the shares are relatively easy to value (since they are already trading) and the number of potential bidders is relatively small, these auctions are closer to Treasury bill auctions than to the types of auctions that have been used for IPOs.

${ }^{27}$ On August 10 2000, Deutsche Bank and Bear Stearns each auctioned off their own debt on their newly-developed platforms, while WR Hambrecht held its first OpenBook debt auction, for Dow, on August 15, 2000. WR Hambrecht handled a second OpenBook auction, for Ford Motor Credit, in March, 2001. It reportedly also attempted an auction for Dayton Hudson, but the bid-taking system crashed during the auction.

${ }^{28}$ Overstock, a company that also went public through an OpenIPO, used the OpenFollowon method in May of 2004 but chose a traditional marketed offering for its next follow-on in November, 2004.
} 
presumably also have sufficient market power to negotiate high fees for auctions ${ }^{29}$. In fact, auctions have usually been replaced by fixed price public offers, and public offer fees are typically as low as, or even lower than, the fees for auctions. Underwriters with market power would have preferred auctions if fees were the only consideration ${ }^{30}$..

Another version of the market power argument takes into account hidden indirect compensation from having discretion over allocations: Underwriters may have an incentive to pressure issuers to use methods that lead to higher initial returns, so that the underwriters can allocate the underpriced shares to their favored clients, possibly in exchange for soft dollar payments. However, that cannot explain the choice between auctions and fixed price public offers, since neither method allows the underwriter to control allocations, and as mentioned earlier auctions were associated with higher fees ${ }^{31}$.

\section{Why Do Issuers Avoid Auctions?}

In this section, we argue in favor of a different reason for the apparent lack of popularity of IPO auctions. In particular, most auction models abstract away from the actual decision-making process of the agents, assuming instead that, whatever the process is, it is consistent with the game-theoretical equilibrium. However, this assumption is often in disagreement with evidence, as indicated by the existence of the winner's curse in many experimental and realworld situations. In order to reconcile this evidence with theory, a number of alternative equilibrium specifications have been proposed, such as level- $k$ bidding (Crawford and Iriberri, 2007), "cursed equilibrium" (Eyster and Rabin, 2005), or quantal response equilibrium (McKelvey and Palfrey, 1995). The common feature of these methods is that they allow agents to deviate from traditional expected utility maximization under Bayesian beliefs and allow for some form of bounded rationality. Allowing for such alternative behavior by agents may be relevant when modeling investors who participate in IPOs given the difficulties involved in valuing IPOs even for sophisticated investors.

Sherman (2005) models participation swings in sealed bid auctions, resulting in increased uncertainty over outcomes, in an equilibrium with rational, informed bidders ${ }^{32}$. As we discuss below, bounded rationality, when combined with fixed costs of participation and dynamic updating of beliefs, can amplify this uncertainty, which can deter rational sophisticated investors from participating, and lead to an increased probability of either low proceeds or even an outright placement failure for the issuer ${ }^{33}$

To make our discussion more specific, consider a "baseline" auction model based on Milgrom (1981) (fully described in Appendix A). Notably, its equilibrium is characterized by fairly low discounts (compared to those often observed in real-life IPOs) even with a modest number of participants (Figure 5), and in presence of risk aversion (Figure 3) and noisy signals (Figure 4).

To see what may be going wrong with auctions in practice, it is important to note two somewhat related issues: (i) the prevalence of the winner's curse in many real-life auctions, and (ii) the relationship between the number of participants and the discount, particularly in a setting when the number of participants can be stochastic.

In what follows, we provide a brief review of the properties of uniform price auctions before illustrating the high level of sophistication that is required to avoid the "winner's curse" while bidding in auctions.

\footnotetext{
${ }^{29}$ A related argument is given by Degeorge et al. (2007), who show a correlation in France between greater publicity/analyst attention for IPOs and the use of book building rather than an auction (they do not analyze the fixed price public offers in their sample). They argue that underwriters induced issuers to use book building by convincing them of the value of other services (more analyst attention). However, the question why such services would be bundled only with book building, rather than with all three methods in use at the time remains a puzzle.

${ }^{30}$ Ljungqvist et al. (2003) show that average fees tend to be quite low for fixed price public offers across most countries, substantially below those for book building. Chahine (2001), examining French data from 1996 to 2000, found that the mean, median and standard deviation of gross spreads were slightly lower for fixed price than for auctions. In most countries, when auctions were first used, the fees were the same for auctions as for fixed price public offers.

${ }^{31}$ Many countries allow orders in fixed price public offers to be favored on the basis of order size, but this usually involves favoring small over large orders. Chowdhry and Sherman (1996b) show that favoring small orders may reduce the Rock (1986) winner's curse. Parlour and Rajan (2005) also examine rationing in IPOs.

${ }^{32}$ See also Hausch and Li (1993) and French and McCormick (1984) on endogenous entry in sealed bid auctions.

${ }^{33}$ Of course, sealed bid auctions are not the only IPO method that may experience participation swings. However, as we discuss briefly at the end of this section, the other two methods are less vulnerable to such swings. For fixed price public offers, participation variations do not affect the offer price; while for book buidling, the underwriter observes the total number of orders before setting either the price or allocations, and thus can adjust for such variations. In Jagannathan et al. (2010) we show that an optimal truth-telling IPO auction mechanism would be characterized by many features that are commonly associated with book building, which simplifies the agents' problem by transferring the "computational burden" to the underwriter, who has immediate interest in making sure that the process stays attractive for both issuers and investors.
} 
Figure 2 shows equilibrium bidding functions (showing an equilibrium bid as a function of an investor's signal), depending on the number of participants in an auction. Note that when $N=2 K$, so that the number of winners is equal to the number of losers, bids are very close to the signals, i.e., little correction for the winner's curse is necessary. However, as the number of participants grows, so does the strength of the negative signal associated with winning the auction: it now implies that the original bidders' signal likely was in the right tail of the distribution and was overstating the underlying share value ("Winner's Curse"). Consequently, bidders shave their bids. On the other hand, when $N<2 K$ so that there are more winners than losers, losing the auction is an indication of the signal biased downwards ("Loser's Curse"), and bidders adjust their bids upwards instead.

Note that if bidders underestimate the number of bidders or under-react to an increase in the number of bidders, they would insufficiently shave their bids, resulting in overbidding. Below we argue that this type of an under-reaction is a likely explanation for the large fluctuations in participation, followed by abandonment of auctions by issuing firms in several countries.

\subsection{Behavioral Biases in Expectation Formation}

As we saw above, the required bid-shaving to avoid the winner's curse depends on the number of other participants in the auction. When there is uncertainty about the number of other bidders, coming up with the correct bidding strategy can be difficult and even apparently sophisticated investors may find it difficult to avoid the winner's curse ${ }^{34}$. In what follows we illustrate the difficulties associated with bidding in an auction with an example somewhat resembling a popular TV game "Let's Make a Deal"35:

Consider an auction similar to the one analyzed in the previous section, where $K=15$ lots of shares are auctioned, and the number of participants, $N$, will be 20 or 150 with equal probability, and each bidder is allowed to bid only for one lot. For expositional convenience assume that all the bidders follow the strategy such that, conditional on winning and getting an allocation, the expected profit will be $\$ 0.50$ when the number of bidders $N=20$, and $\$-1.00$ when $N=150$.

An apparently sophisticated investor may calculate the expected profits to bidding as follows: The probability of winning is $15 / 20=0.75$ when $N=20$ and $15 / 150=0.10$ when $N=150$. Therefore the expected profit to participating is $\$ 0.50 \times 0.75=\$ 0.375$ when 20 bidders participate; and $\$-1.00 \times 0.10=\$-0.10$ when 150 bidders participate. Since $N=20$ and $N=150$ are equally likely, it appears reasonable to calculate the expected profit to participating in the auction as

$$
\frac{1}{2} \times \frac{15}{20} \times \$ 0.5+\frac{1}{2} \times \frac{15}{150} \times \$-1=\$ 0.1375
$$

Note that aggregate total expected profit to to all the participants taken together is given by:

$$
\frac{1}{2} \times \frac{15}{20} \times \$ 0.5 \times 20+\frac{1}{2} \times \frac{15}{150} \times \$-1 \times 150=\$-3.75 .
$$

In other words, while each bidder expects an average profit of $\$ 0.1375$ from participating in the auction, collectively the expected profit to all those who participate is $\$-3.75$. Obviously something is wrong with the calculations given above. The mistake is that the bidder did not correctly take into account the fact that whenever she herself participates, it is more likely that others are participating as well, or in other words when she participates $N=150$ is more likely than $N=20$. The conditional probabilities of participating are not identical, as is implicitly assumed in the earlier calculation.

In order to correctly calculate the conditional probabilities, it is convenient to assume (without loss of generality) that $N$ bidders are chosen at random from the pool of all potential participants, i.e., 150. Then, the probability of being chosen to bid when $N=20$ is $20 / 150=0.13$, and the probability of being chosen to bid when $N=150$ is $150 / 150=1.00$ The correctly computed ex-ante expected profit to each bidder is given by:

$$
\frac{1}{2} \times \frac{20}{150} \times \frac{15}{20} \times \$ 0.5+\frac{1}{2} \times \frac{150}{150} \times \frac{15}{150} \times \$-1=\$-0.025
$$

\footnotetext{
${ }^{34}$ While it may be possible to fix the uncertainty about the number of bidders in an auction, it will be difficult to address the uncertainty associated with how much those other bidders know and how they will bid.

${ }^{35}$ http://en.wikipedia.org/wiki/Let's_Make_a_Deal
} 


\section{Simulated Uniform-Price Auctions.}

Allocations and discounts in simulated uniform-price unit-demand auctions. Unless otherwise specified, the log of the value of a share and the log of each signal about the value of the share are jointly normally distributed with $\sigma_{V}=\sigma_{S}=0.3$ and $E V=E S=10$. There are $N$ participants, each bidding for at most one lot of 100,000 shares, with the total of $K=15$ lots offered. Except in Figure 3, all bidders are risk-neutral.

Even with zero information, transaction and opportunity costs, an open auction does not completely eliminate underpricing. It occurs due to the finite number of participants, and becomes larger when bidders are risk-averse. The auction discount, depending on the number of participants and their degree of risk aversion, is shown in Figure 3. Note that, in this example, even when the number of participants is relatively small, the auction discount is low when bidders are risk neutral (between $1 \%$ and $2 \%$ in the twice-subscribed case of $N=30$ ). The discount can go up substantially when bidders are sufficiently risk averse and ill diversified.

Aggregate uncertainty, which enters this model due to imperfect revelation of the true underlying value through a limited number of noisy signals, increases the expected discounts, as one can see from Figure 4. For example, when the standard deviation of the signal doubles, the underpricing in the twice-oversubscribed auction also doubles. As the number of participants grows, price discovery improves, and both mean expected discount and their variance are reduced (Figure 5).

\section{Figure 2: Bidding Functions}

\section{Equilibrium bid}

as a function of signal for different numbers of risk-neutral participants $N$.

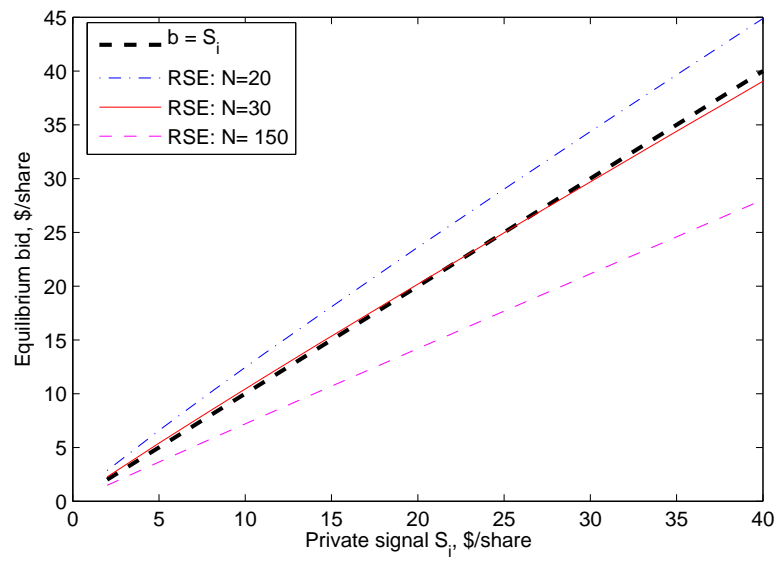

Figure 4: Signal Quality and Discount

Equilibrium expected discount for different values of noise $\sigma_{S}$ and number of risk-neutral bidders $N$.

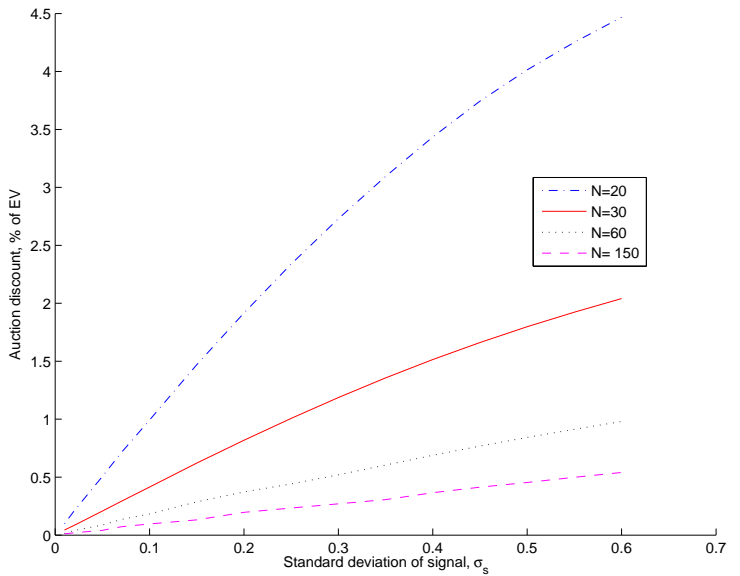

\section{Figure 3: Discount and Risk Aversion}

Expected auction discount for different numbers of bidders $N$ and different risk aversion.

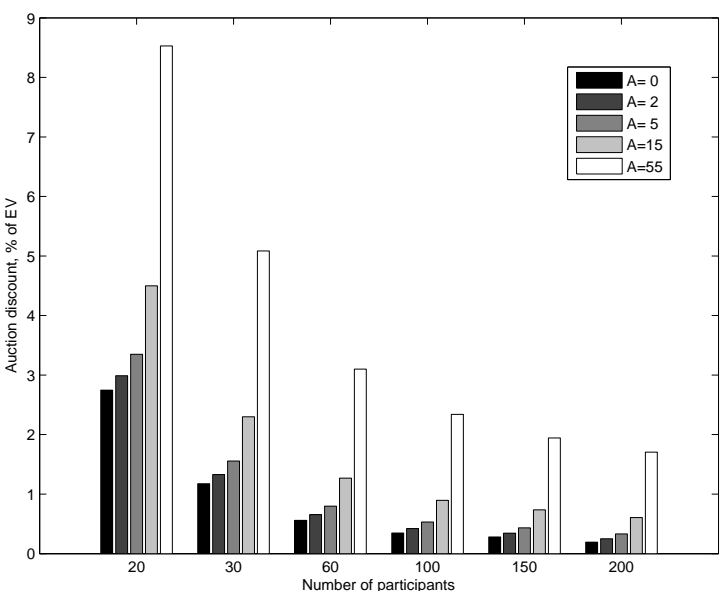

Figure 5: Discount, \% of EV

Probability distribution of auction discount for $N=20$ and $N=150$

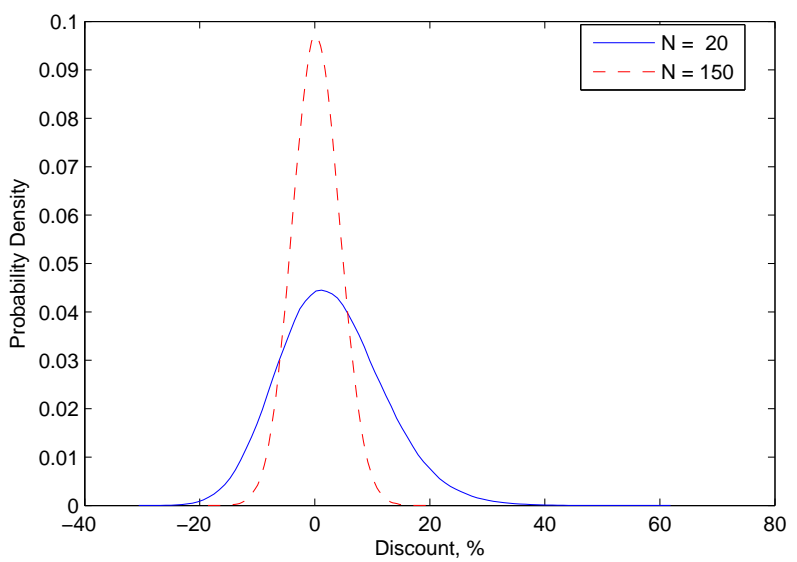


Hence the collective expected profit of all 150 potential bidders is $150 \times \$ 0.025=\$-3.75$ same as what we computed earlier.

\subsection{Dynamic updating}

Now, consider an economy populated by $M$ potential "naive" investors. Each period $t$, each investor $i$ faces a fixed cost of participating in an auction $c_{i}$, and receives a private signal $s_{i}$ about the true value. These investors are "naive" in the sense that if they choose to participate, they simply bid their valuation, or follow another bidding strategy, such as shaving their bids by a fixed amount, that does not change from auction to auction, and only depends on the private signal $^{36}$.

They decide whether to participate based on their expectation of return in the auction, minus the fixed cost. Their expectations of return to participation is adaptive, and is equal to a weighted average of the return on all past auctions that they know about, and their own return on the auctions they have personally participated in.

Now, individual participation and observed returns to investors in these auctions will vary. Due to the bias inherent in the "let's make a deal" example, however, any investors who have not yet participated in an auction will overestimate their returns to participation, and after a short initial period of higher discounts and lower participation, there will be a period of negative returns and high oversubscription. This period will continue until either (i) sufficiently long "bad" history is established, or (ii) sufficiently many investors learn not to participate based on their own experience, at which time they will stay away, and only a similarly long history of positive returns could induce them to participate again.

However, since the issuers are highly averse to a risk of auction failure, and since at this point auctions would (again) have low subscription and high discounts, they offer no advantages to issuers over either fixed price or book building offers, and thus issuers would prefer other methods, and such a positive history would never be established. This is observed in practice as auction failure.

There is, however, a possible compensating effect: the above reasoning relies upon assumption of "naive" investors; perhaps more sophisticated investors could step in and provide the demand when naive investors decide to stay out? In what follows, we argue that it is unlikely to be the case ${ }^{37}$.

\subsection{Structural Risk in IPO Auctions}

The folk wisdom is that wider participation IPO auctions must necessarily be in the interest of the issuer, due to better price discovery, increasing proceeds and decreasing risk. However, in practice imprecise valuation is not the only source of aggregate risk in IPO auctions. Much of it comes from the features of the bidding environment itself, such as the variation in the number and strategies of other bidders. This variation has historically been very high.

For example, when Japan auctioned off parts of its railway system, the 1993 auction of Japan Railway (JR) East drew 18,670 bidders, while the 1996 auction of JR West drew only 3,395 bidders, a decrease of more than $80 \%$. 335,000 JR West shares (20\%) were left unsold. When Argentina auctioned off its first telecommunications company, Telefonica, in December, 1991, it hoped for at least 80,000 bids from local investors but received more than 100,000. When it auctioned off its other telecommunications company, Telecom, just a few months later, the auction drew more than 270,000 applications from local investors.

Amihud et al. (2003) found large fluctuations in the number of bidders for IPO auctions in Israel. Similarly, Kandel et al. (1999) looked at 28 auctions over 3 years in Israel and found that orders ranged from 1,388 to 13,518 $8^{38}$. Lin et al. (2003) and Hsu and Shiu (2004) report wide fluctuations in bidder numbers for Taiwan's IPO auctions. There is also evidence of variation in the demand for Singapore auctions ${ }^{39}$. Subscription levels ranged from the Vickers Ballas auction, which was $1,300 \%$ oversubscribed (at the minimum bid), to Sunright, which was $82 \%$ undersubscribed. The number of bids ranged from 1,128 for Eng Wah to 162,492 for Singapore Telecom. In the same month that Singapore

\footnotetext{
${ }^{36}$ Kagel et al. (1995) found that in an experimental setting "bidders fail to respond in the right direction to more rivals".

${ }^{37}$ Munger mentions in Poor Charlie's Almanack (2006, page 18) that he avoids auctions since "The problem with closed bid auctions is that they are frequently won by people making a technical mistake, as in the case with Shell paying double for Belridge Oil.” See also Dyer et al. (1989).

${ }^{38}$ Multiple orders were allowed, so the number of orders might overestimate the number of bidders.

${ }^{39}$ Data available on request
} 
Telecom's auction was heavily oversubscribed,the auction of another well-respected Asian telecommunications company, Korea Telecom, was $90 \%$ undersubscribed (i.e. received orders for only $10 \%$ of the available shares). While some of these variations in participation levels would have been anticipated, there would have been some surprises.

We illustrate the effect of structural risk by considering an environment similar to the baseline model, but with added uncertainty about the number of bidders. For simplicity assume that all bidders are identical and there are $L$ potential bidders, out of whom either $N_{1}$ or $N_{2}$ get to participate, with ex ante probabilities $p$ and $1-p$.

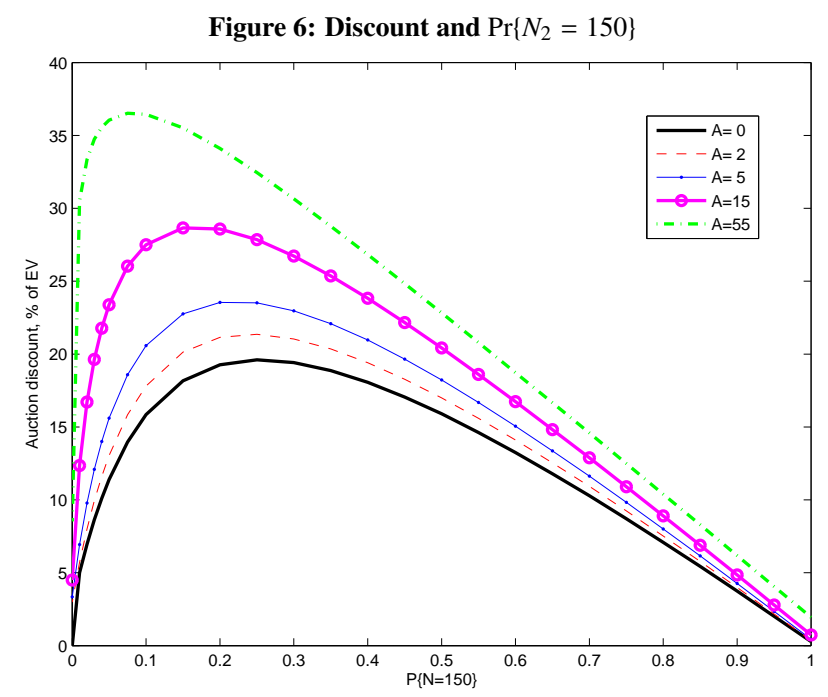

Figure 6 gives the expected discount when the probability of $N_{1}=150$ varies from 0 to 1 for different values of risk aversion of bidders. The expected discount is small when there is no uncertainty about the number of bidders. However when the bidders face additional risk from underestimating the competition (i.e., there is a positive probability of $N=150$,) the expected discount increases. It is highest when the uncertainty about the number of bidders is high, and the risk aversion of the bidders is also high. Restricting the number of participants to 20 bidders in this case would result in an outcome clearly superior for the issuer - even though it means abandoning openness, which is lauded as one of benefits of auctions.

In addition to high discounts, randomness in participation greatly increases the variance of outcomes. To fully appreciate the risk faced by investors, consider the case where the probability of $N=150$ is $50 \%$, and the coefficient of risk aversion $\mathrm{A}=2$. In this case, the return to a winning bidder is positive about half of the time, mostly when the number of bidders is below average. In the low-participation auctions, winners have an expected rate of return of $66.6 \%$, with $75 \%$ of such auctions returning at least $56.1 \%$ and $25 \%$ returning $76.1 \%$ to the winning bidders, while in the high-participation auctions the situation is very different: the winners take losses in $97.3 \%$ of the auctions, with an average return of $-7.4 \%$. In $75 \%$ of the high-participation auctions, winners lose more than $4.8 \%$, with a $25 \%$ chance of losing $10.0 \%$ or more. Thus, although the return is positive for winning bidders on average, there is substantial risk.

It is necessary to note that there are ways of designing auctions in order to control this risk: for example, requiring bidders to indicate their intention to bid before starting an auction, with a subsequent revelation of the number of participants prior to bidding, would reduce both the risk the bidders would face and the return they would demand. However, such practices so far have not been used for auctions of IPOs ${ }^{40}$. Giving bidders guidance regarding the bidding trends of others also reduces bidder uncertainty, although at the expense of less transparency and more potential abuse by the underwriter/auctioneer. This essentially moves IPO auctions closer to book building as it has traditionally been practiced. Other forms of auctions, including ascending price auctions, and auctions where the highest bidders do not necessarily get larger allocations, may also lead to more robust outcomes.

\footnotetext{
${ }^{40}$ The Google, Netsuite, and Rackspace IPO auctions in the U.S. required bidders to acquire unique bidder IDs before the auction began, but the total number of unique IDs awarded was not announced.
} 
Auctions are not the only IPO method for which there have been fluctuations in the number of participants, of course. However, the timing of sealed bid auctions and their method for determining the offer price make unanticipated variations in subscription levels more problematic than for the other two main IPO methods. With fixed price public offers, the subscription level affects a person's chance of getting shares but not her return, conditional on getting shares, since the subscription level does not affect the offer price. With book building, the underwriter observes the subscription level as well as the 'bids' and can then set the price, taking the subscription level into account.

In addition to uncertainty about the number of bidders, disruption can result when some bidders place noncompetitive (i.e. arbitrarily high-priced) bids. In a uniform price auction, such "free riding" places the bidder first in line for shares but may have little effect on the clearing price. However, each such bid reduces the pool of shares available to investors who actively participate in price discovery. In our earlier example where there is a $50 \%$ probability of 20 sophisticated bidders and a $50 \%$ probability of 150 sophisticated bidders, suppose there is also a chance that five uninformed free riders may unexpectedly enter, bidding a sufficiently high price to be sure of getting shares. If the auction turns out to have a low participation level of only 20 sophisticated bidders, the expected return to a winning bid is $66 \%$ with no free riders but only $36 \%$ with 5 unexpected free riders. If it is a high participation auction, the expected return to winning bidders is $-7 \%$ without free riders and falls to $-13 \%$ with 5 unexpected free riders. The problem is that, with 5 free riders, sophisticated bidders think that they are bidding for 15 units when in fact they are competing for 15 - $5=10$ units, and hence are not shaving their bids sufficiently.

Thus, if the other bidders do not anticipate the free riders and adjust their bids accordingly, their expected return will be lowered. If other bidders have rational expectations regarding the distribution from which the number of free riders comes, they will shave their bids accordingly, lowering the expected proceeds to the issuer. As with uncertainty over the total number of bidders, uncertainty over the number of free riders increases risk for both issuers and investors, even in an equilibrium in which everyone's expectations are correct on average. Thus we argue that uncertainty over the number of bidders, their information sets or their bidding strategies can lead to more underpricing, more risk and less accurate pricing.

\subsection{Summary}

In this section, we first modeled auctions in a frictionless environment in which all eligible bidders are endowed with valuable private signals and bid in every auction. In this case auctions are underpriced on average, but not by much when bidders are risk neutral and there are sufficiently large numbers of bidders. Risk aversion on the part of bidders increases the average underpricing, but auction discounts are still relatively low. This is the oft-cited auction solution in which more bidders leads to a more efficient result, with underpricing largely vanishing once sufficient numbers of investors bid. Hence, in a frictionless world with no information generation costs, auctions lead to highly efficient pricing as long as they are open to large numbers of informed, sophisticated bidders.

We next examined some more realistic settings, beginning with one in which there is uncertainty over the number of bidders. Bidding becomes difficult when there is uncertainty about the number of bidders, how much they know and what strategies they will follow, leading to more risk, more underpricing and less efficient price discovery. Free riders (those who choose to bid very high to be first in line, without investing in information generation) add risk for other bidders and for the issuer, with the issuer ultimately having to underprice more because of the presence of potential free riders. That suggests a role for monitoring bidders and limiting their access to reduce the free riding problem.

Last, we showed that it is not easy to bid in auctions, and that even sophisticated bidders can make mistakes. When investors make bidding errors, or when they follow suboptimal strategies such as return-chasing, costs are imposed not only on those bidders themselves but on all auction participants and ultimately on issuers. The bidding errors and problems that we have shown in this section appear to match the problems that have occurred in practice in many auctions around the world, as we will explore in more detail in the next section.

\section{Empirical Evidence}

In this section we first provide some anecdotal evidence supporting the arguments in the earlier section. We then examine the evidence from Singapore in greater detail. Finally we discuss the US experience with auctions for Treasury securities. 


\subsection{Anecdotal Evidence on Initial Returns}

It is necessary to note that auctions often lead to very large first day gains or losses. Appendix C.1 lists examples of IPO auctions that have led to large first day gains, while Appendix C.2 gives examples of negative first day returns. One example is the 1993 auction of Japan Railway East, which was in such strong demand that it was heavily oversubscribed and yet traded as high as $70 \%$ above the auction clearing price on its first day. In contrast, the later auction of Japan Railway West attracted only about one-fifth as many bidders and was $20 \%$ undersubscribed. When El Al, the Israeli Airline, was auctioned off in 2003, the IPO was widely considered a hot offering. However, demand was so unexpectedly low that orders barely covered the minimum number of shares. Within days, the stock was trading for more than double the auction price (a 112\% increase) on the Tel Aviv Stock Exchange, and investors were complaining that the process had been unfair,because more people would have bid if they had known that the auction price would be so low. However, by the very nature of sealed bid auctions, no one knows how many others have placed bids until after the bidding period has closed, when it is too late to respond.

Argentina offers an example of how success with one auction can lead to problems with the next. Argentina began a massive privatization program with the auction of shares in Telefonica de Argentina in December, 1991. Institutional demand was lower than expected, since many professional investors thought that the minimum bid price was too high. However, massive interest by retail investors drove the auction clearing price to $45 \%$ above the minimum bid. The stock rose another $20 \%$ during aftermarket trading, and the auction was described as a "smashing success". The next privatization, for Argentina Telecom, came less than four months later. Because the Telefonica auction had been such a success, many were eager to cash in on the Telecom auction. Bids totaled almost 6 billion pesos, although the government had only hoped to raise 1 billion pesos. The auction price was bid up to almost twice the reservation price, due to the strong demand from local investors. The initial return on Telecom's IPO (based on the first day's closing price) was $3.6 \%$, which means that the stock would be considered fairly accurately priced in most academic studies.

But the auction price was unsustainable. Many investors had funded their purchase with 90 day margin loans, and by the time those loans were due, the stock price had fallen far enough that many discouraged investors chose not to meet margin calls on their Telecom shares, while others sold other shares to meet their Telecom margin calls. Brokerages had to dump more and more shares onto the market because of missed margin calls, causing a general market crash and the cancellation of up to 20 other planned IPOs in Argentina. Telecom was later described as "viciously overpriced" because, according to a banker at Banco de Galicia, "Everyone had seen how well Telefonica (the other telephone privatization) had gone, and their total analysis was 'if Telefonica was a sell-out then Telecom will be too'. What happened was that the Dutch-auction system exacerbated things because people pushed up their price to make sure they would get shares." 41

Thus, there are many examples of extreme initial returns resulting from IPO auctions. These do not prove that auctions are inferior to other issue methods, since other methods have also led to large positive or negative initial returns. Nevertheless, these examples show that the pricing accuracy of the sealed bid IPO auction method should not be taken for granted. Regarding the question of whether auctions lead to less underpricing, relative to book building, the overall evidence is surprisingly weak, since there is little data that allows a direct comparison. The relevant comparisons that have been made to date are the following:

- France: Auctions co-existed with a restricted, sub-optimal form of book building (a sequential hybrid, rather than 'open pricing' which is a simultaneous hybrid) until 1999, when more standard book building was allowed and auctions were quickly abandoned. Derrien and Womack (2003) found that the differences in underpricing between auctions and book building were "small and statistically insignificant when examined unconditionally" (page 47), but that auctions were better than the sequential hybrid book builds in their "ability to incorporate more information from recent market conditions into the IPO price" (abstract), thus confirming that the differences were due to the regulatory restrictions on book building that were later eliminated.

- Japan: Auctions were required for many years but vanished quickly in 1997, once book building was allowed. Thus, the two methods did not overlap but were used in close succession. Kutsuna and Smith (2004) found a small but statistically significant increase in initial returns under book building, and also found that a wider range of companies, including younger start-ups, were able to go public under book building.

\footnotetext{
41”Argentina’s Stock Regulator Faces Daunting Task", The New York Times; August 24, 1992, Section D, p. 3.
} 
- India: Regulations were changed in 2005 to prohibit book building, replacing it with auctions. Bubna and Prabhala (2009) find that auctions led to more underpricing, relative to book buildng.

The evidence is inconclusive, since auctions have led to less underpricing in Japan, more underpricing in India and to no statistically significant difference in France, relative to book building.

\subsection{IPO Auctions in Singapore}

The available data on auctions is sparse and not easily amenable to rigorous quantitative analysis using statistical methods, since most countries that have tried IPO auctions gave up on them after a few years, leading to small samples. For example, the influential Kandel, Sarig and Wohl (1999) paper is based on only 28 IPO auctions in Israel, while Degeorge, Derrien and Womack (2007) examine only 19 auctions in the U.S. Moreover, data on participation levels are often unavailable.

Singapore's IPO auctions during 1993-1994 present an interesting natural experiment and an illustration of some of the potential issues that we believe is of general relevance. We have data on the full sample of all 20 uniform price IPO auctions in Singapore, and will attempt a quantitative characterization of that data in this section.

The lessons from the Singapore experience are relevant for several reasons. First, Singapore is a sophisticated financial center whose banking and security markets are well regulated. One example of its technological sophistication is the fact that IPO auction bidders beginning in 1993 could place their bids through automated teller machines (ATMs), thus making those auctions as widely accessible as online internet auctions are today. The Singapore stock market in 1993 was fairly well developed and active, with two active exchanges, 241 public companies traded, and $\mathrm{S} \$ 280$ billion of average daily dollar transaction volume ${ }^{42}$.

Singapore's uniform price auctions were hybrids and thus were well suited to reduce the impact of free riders, since uninformed investors could also participate, without specifying a price, through the simultaneous fixed price tranche. Therefore, if there is evidence of free riders including return chasers becoming an issue in hybrid uniform price auctions, they are likely to be even more of an issue in 'pure' uniform price auctions.

\subsubsection{The Data}

We use data on all 20 Singapore IPO issues that were held during 1993-1994, which include 20 uniform price hybrid auctions (tenders) and 31 pure fixed price issues ${ }^{43}$. The available statistics include size of individual tranches (fixed price, tender, employee, and private placement), number of shares outstanding and offered, IPO clearing price, interval data on bids collected (number of bids and number of shares bid in a given price range), obtained from the Stock Exchange of Singapore.

In addition we use market performance data from Bloomberg Finance L.P., and an archive of Singapore Englishlanguage financial press available through Lexis-Nexis Academic.

The main shortcoming of our data is its fairly low duration - there were only 20 IPO auctions conducted in Singapore during those two years, and the method has never been tried there again.

For each of auctions $t=1 . . T$ we know:

- $J_{t}$ bid intervals $\left[\underline{b}_{j t}, \bar{b}_{j t}\right], \bar{b}_{J_{t} t}=+\infty$

- $q_{j t}$ : the total number of shares applied for in $\left[\underline{b}_{j t}, \bar{b}_{j t}\right]$

- $n_{j t}$ : the total number of applications in $\left[\underline{b}_{j t}, \bar{b}_{j t}\right]$

- $m_{t}$ : Clearing price

Figure 7 illustrates the bid distribution in the 20 auctions. Each circle represents the low point $\underline{b}_{j t}$ of a range for a group of bids in a particular auction; circle size is proportional to the relative size of that group within the auction. Fixed price is normalized to 1 for all auctions. " $\mathrm{x}$ " denotes the price after 1 year. Auction clearing price $m$ is on the horizontal axis. Blue solid line is a " 45 -degree" line $\underline{b}_{j, t}=m_{t}$ and denotes locations of the marginal winning bids. 


\section{Figure 7: Bidding in Singapore IPOs}

Each circle represents the low point of a range for a group of bids in a particular auction; circle size is proportional to the relative size of that group within the auction. Fixed price is normalized to 1 for all auctions. "x" denotes the price after 1 year. Auction clearing price on the horizontal axis. A "45-degree line" denoting locations of the marginal winning bids in blue. "High" and "Low" expected demand auctions are ranked according with demand forecasted using the specification in (3).

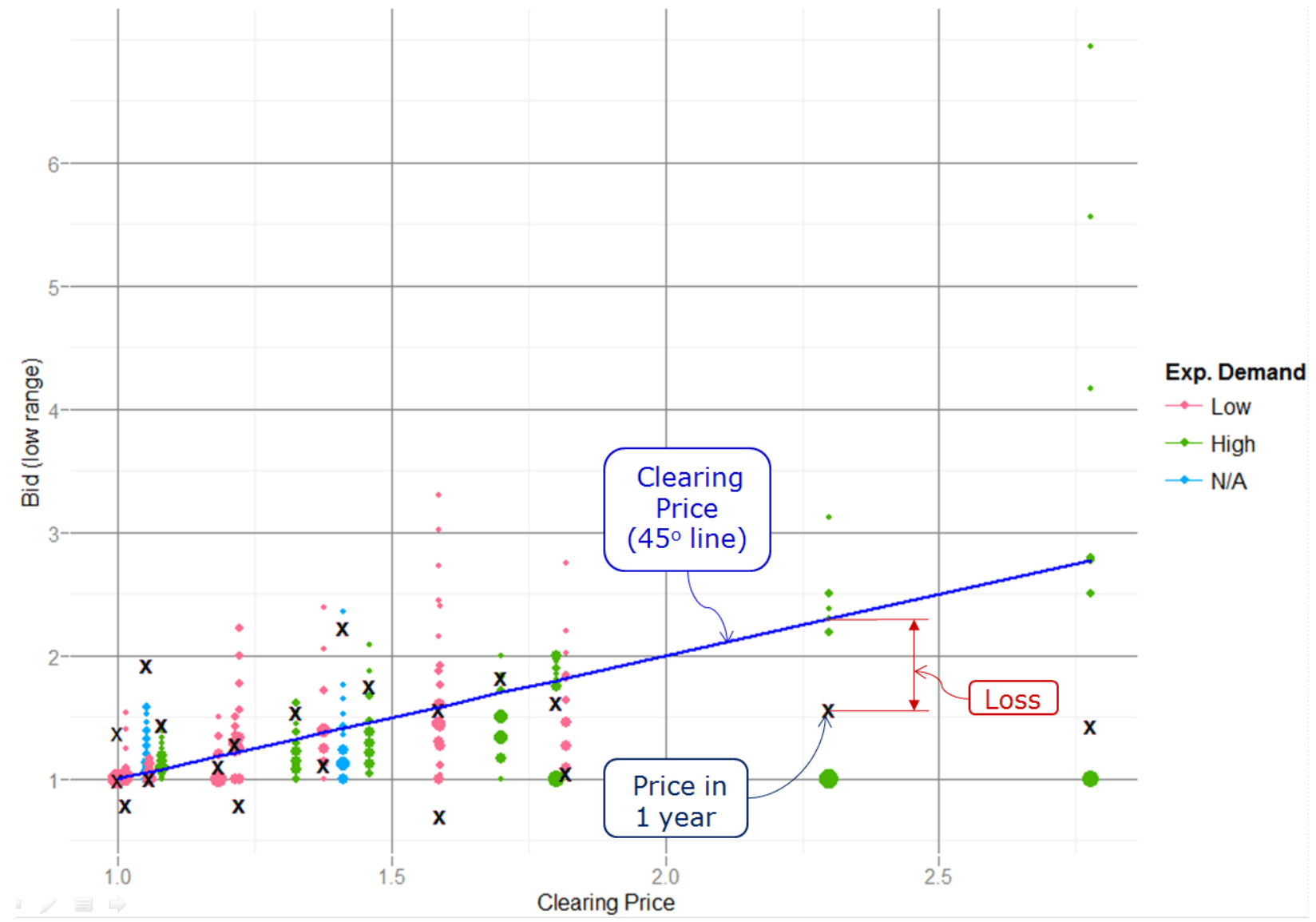


Figure 8: Singapore IPO Issues: Size, Time, and Annual Returns

Top panel: 1-year market adjusted return vs. subscription closing date. Color: subscription rate (ratio of shares applied to shares offered). Colored circle proportional to value of the tender tranche. Gray area proportional to fixed price tranche. Thin solid circle proportional to market value (all evaluated at the fixed tranche price). Thin dotted line shows aftermarket movement from first day close.

Bottom panel: Thick green line: 90-day cumulative return on the STI index. Thin red line: 90-day cumulative return on a buy-and-hold portfolio of last 4 tender IPO shares, purchased at tender price (equally weighted)

Sources: Stock Exchange of Singapore and Bloomberg Finance L.P.

\section{Singapore Auctions}
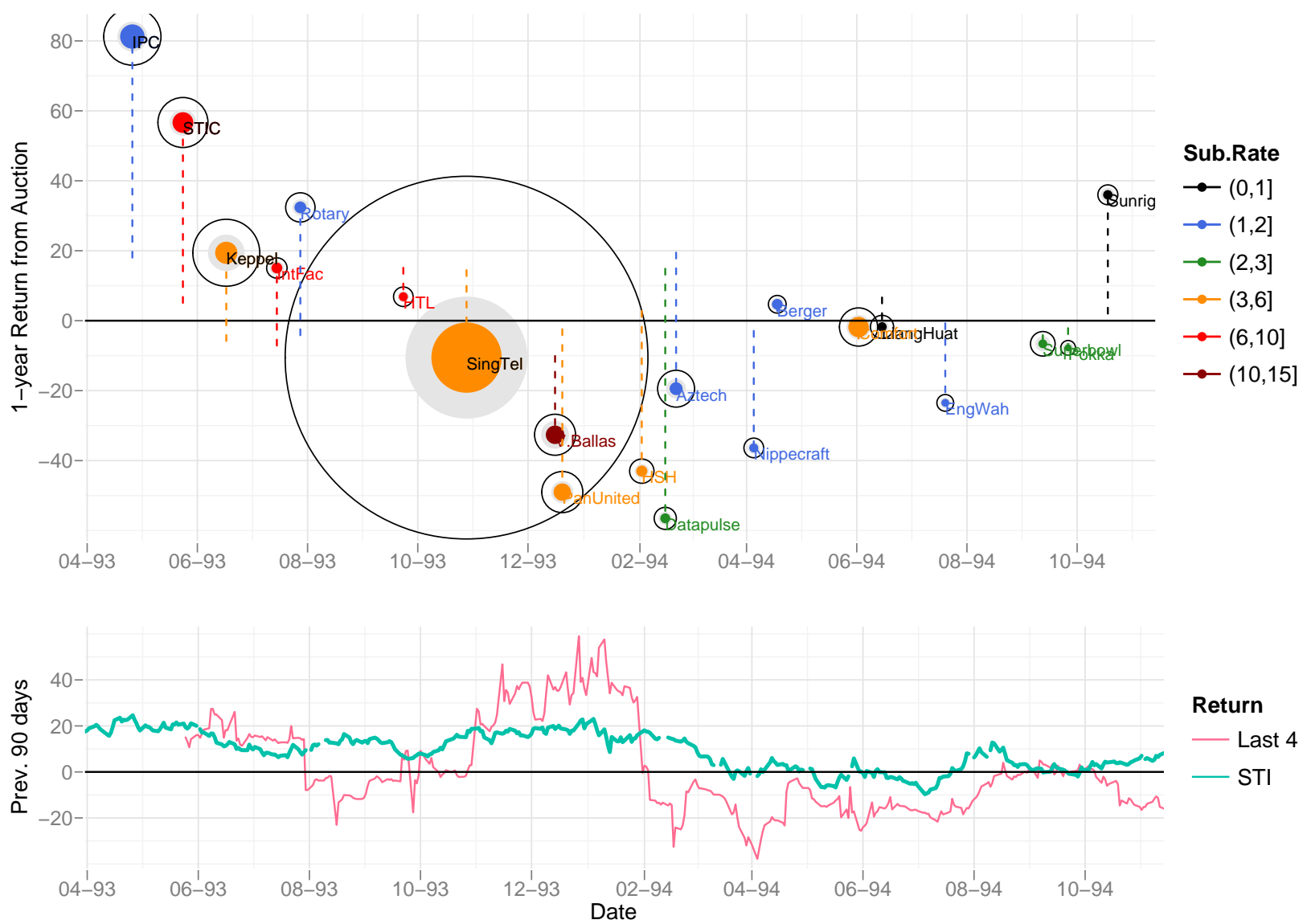
All 1993-1994 auctions are ordered by date. One month raw returns are the returns to winning bidders that held their shares for 30 days in the aftermarket. The 4-IPO moving average is the average return on the last 4 offers (or all previous, if less than 4). The oversubscription rate is in percent - an offering that was $60 \%$ oversubscribed received orders for 1.6 times the shares available.

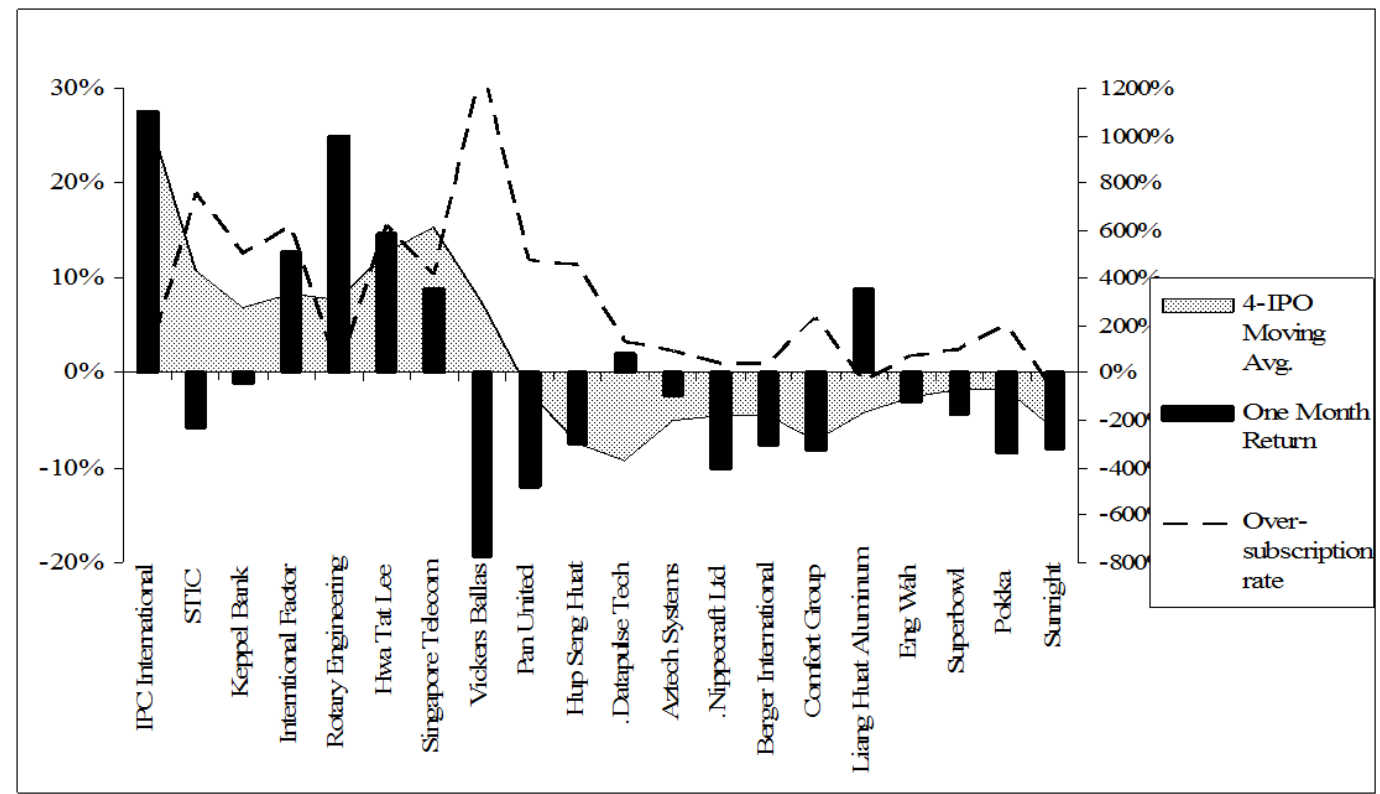

\subsubsection{Singapore IPOs: a Short History}

The hybrid auction scheme was first introduced as an option for Singapore on July 29, 1991, when companies were allowed to offer part of the issue in a "Dutch" (discriminatory) auction. It, however, has not gained much popularity, with only one Dutch tender IPO (Singapore Computer Systems) in 1991, and one more (Keppel Integrated Engineering) in $1992^{44}$. No other IPO auctions took place in Singapore until February 1993, when an alternative uniform price ("French") auction system was introduced.

A timeline showing Singapore IPO auctions' size, 1-year returns and subscription levels in 1993-1994 is shown in Figure 8 and Table 2.

Figure 9 provides visual evidence of how Singapore's auctions evolved over time by plotting one month returns and subscription levels for all of Singapore's auctions, ordered chronologically. Although there were variations, the returns and participation levels for IPO auctions fell over time. Investors would have made money on five of the first seven uniform price auctions (known as tenders) in Singapore, if they had bought at the auction strike price and sold after the shares had traded for one month. The average raw return on the first seven offerings was $11.7 \%$, for this holding period, and the average oversubscription ratio was 4.2 (420\% oversubscribed). However, the returns were negative for seven of the last eight auctions done in Singapore, with an average one-month return of $-5.1 \%$ for these auctions (tenders $)^{45}$. People noticed the poor performance, complaining that auctioned IPO shares were falling below

\footnotetext{
${ }^{42}$ Daily average exchange rate in 1993 US $\$ 1=$ S $\$ 1.57$

${ }^{43} \mathrm{~A}$ list of these is available upon request, along with a detailed description of the regulations.

${ }^{44}$ See Hameed and Lim (1998)

${ }^{45}$ A similar pattern occurred for the 19 U.S. IPO auctions that have been lead-managed by WR Hambrecht from 1999-2007 analyzed in Degeorge et al. (Forthcoming). For the first 9 IPOs, from 1999-2003, the mean initial return is 29.1\% with a standard deviation of 84.3\%. Excluding Andover.net, which is arguably an outlier, the mean and standard deviation are $1.3 \%$ and $11.5 \%$. For the next 10 IPO auctions from $2004-2007$, the mean initial return is $-0.1 \%$ with a standard deviation of $5.3 \%$. This less attractive performance, from the standpoint of investors, in the second half of the sample may at least partially explain why there have been no OpenIPOs since May, 2007. However, there have since been two other U.S. IPO auctions lead-managed by other investment banks - Netsuite in December, 2007 with an initial return of 36.5\% and Rackspace in August, 2008 with an initial return of $-19.9 \%$.
} 
Table 2: Singapore Tender IPO Issues: Subscription and Returns

Subscription rate is defined as a ratio of the number of shares applied for in a tender issue to the number of shares available as of the closing date of the subscription period. The raw returns are total returns to a bidder who purchased a share at the auction clearing price and sold at the close of the corresponding period. Adjusted returns are defined as the difference between raw and market returns (as measured by the Straits Times Index) in the corresponding period. All market returns are adjusted for dividends.

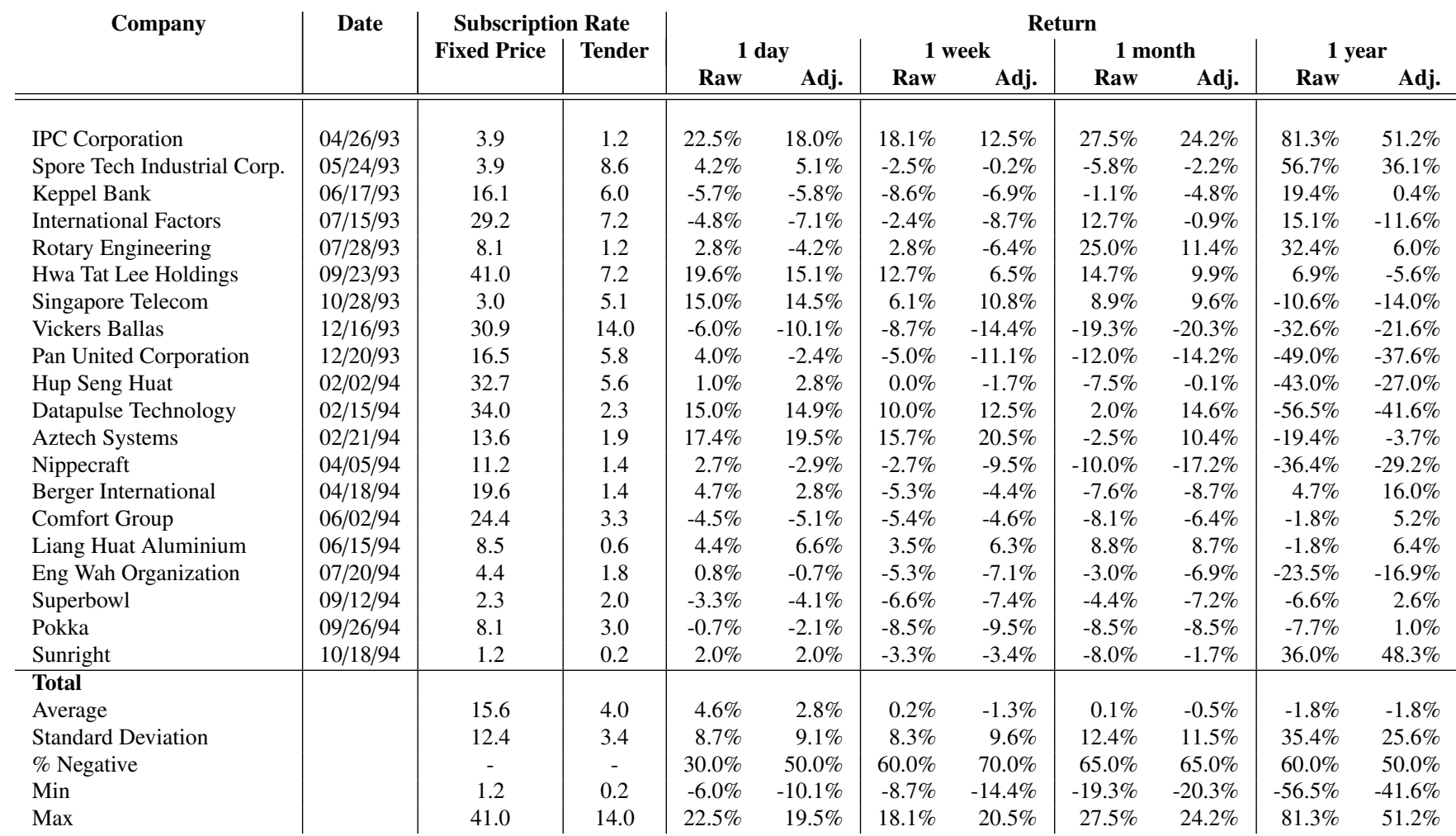


their auction strike price on the aftermarket and joking that they must be catching a new disease called "tenderitis" 46 .

While the oversubscription level for the last eight auctions was 0.7 , which means that offerings were still on average $70 \%$ oversubscribed, this was substantially lower than the average of $420 \%$ oversubscription for the first 7 auctions. Two of the last five auctions were undersubscribed, including the last auction, for Sunright, which received bids for only $18 \%$ of the shares available. The average number of bidders per auction was 48,095 for the first seven auctions $^{47}$ and 6,494 for the last eight. The decrease in returns is similar if we calculate the one month returns relative to the Straits Times Index (blue chips) or Sesdaq Index (smaller, younger companies), or if we use two month returns. It would appear that for investors who were learning and updating their priors over time, auctions became less attractive.

We argued in Section 4.3 that a large number of unanticipated bids will result in the auction clearing price being too high, whereas a surprisingly low subscription rate will lead to large underpricing. We further observed that unanticipated free riders, including return-chasers, may make auctions less attractive for sophisticated investors. We examine the data in three steps to see whether there is support for these conjectures.

\subsubsection{Evidence of Return-Chasing Behavior}

Here we investigate what factors affect popularity of a particular IPO auction and whether there is evidence of return-chasing behavior.

First, we check whether high returns to participating in the preceding auction leads to a higher participation rate in the current auction, using the following regression (Equation 1):

$$
S_{A i}=\alpha_{0}+\alpha_{1} S_{F i}+\alpha_{2} r_{i, l a g 30 d}+u_{i}
$$

where:

- $S_{A i}$ is the subscription rate in the $i^{\text {th }}$ auction;

- $S_{F i}$ is the subscription rate in the fixed price tranche, included here to control for unobserved issue-specific factors affecting the demand for shares;

- $r_{i, l a g 30 d}$ is the return that would have been obtained by buying in the $(i-2)^{\text {nd }}$ auction and selling one month after trading begins.

Since in Singapore the auction and fixed price tranches occurred simultaneously (as opposed to countries like Taiwan where tranches took place sequentially,) fixed price tranche demand is a good proxy of overall demand at the time of the auction.

For the return from a previous auction, $r_{i, l a g 30 d}$, we use the return from 2 auctions ago because the one month return on the $(i-1)^{s t}$ auction is in general not available by the time the $i^{\text {th }}$ auction is open for bidding ${ }^{48}$. We also consider the following variation (Equation 2) of equation (1) above:

$$
N_{A i}=\alpha_{0}+\alpha_{1} N_{F i}+\alpha_{2} r_{i, l a g 30 d}+u_{i}
$$

where:

- $N_{A i}$ is the number of persons bidding in the ith auction divided by the dollar value of shares offered in the auction tranche, at the reservation price;

- $N_{F i}$ is the number of persons bidding in the ith auction's fixed price tranche divided by the dollar value of shares offered in the fixed price tranche.

\footnotetext{
46 "New strategies needed for future IPOs", Ven Sreenivasan, Singapore Straits Times, p. 13, February 3, 1995.

${ }^{47}$ The average is 23,196 for the first six auctions, excluding the unusually large Singapore Telecom offering.

${ }^{48}$ In two cases we had to use the 30 day return on the $(i-3)$ 'rd auction since the return on the $(i-2)$ 'nd auction was not available when the $i$ 'th auction opened.
} 
The results are shown in Table 3, and seem to indicate the presence of "return-chasers". The coefficients for both variables have the predicted sign and are significant at the $1 \%$ level. The auction subscription rate and number of bidders are significantly positively related to our proxy for overall demand, as expected. And, after controlling for demand, the subscription rate or number of bidders is significantly positively related to the return on the second-to-last auction, which is a sign of return-chasing. The $R^{2}$ is $60 \%$ for Equation 1 and $39 \%$ for Equation 2 .

\section{Table 3: Determinants of Auction Subscription in Singapore}

The dependent variable is the auction subscription rate (ratio of the total number of shares requested in all bids to the number of shares offered) for Equation 1 and the number of bidders in the auction for Equations 2 and 3. The subscription rate or number of bidders in the fixed price tranche are used to control for overall demand for the shares. Other controls: 90-day cumulative return on a buy-and-hold portfolio of last 4 tender IPO shares, purchased at tender price (equally weighted), and an increased news coverage dummy (see Section 5.2.3 for details).

\begin{tabular}{|c|c|c|c|}
\hline & Eq. 1 & Eq. 2 & Eq. 3 \\
\hline Subscr. rate in fixed tranche & $\begin{array}{c}0.18^{* * *} \\
(4.27)\end{array}$ & & \\
\hline Number bidding in fixed tranche & & $\begin{array}{c}3.18^{* * *} \\
(3.29)\end{array}$ & \\
\hline 1 month ret. on next-to-last auction & $\begin{array}{c}14.18^{* * *} \\
(3.5)\end{array}$ & $\begin{array}{c}0.11^{* * *} \\
(2.26)\end{array}$ & \\
\hline 90-day ret. of 4-auc. portfolio & & & $\begin{array}{c}11.05^{* * *} \\
(4.14)\end{array}$ \\
\hline Increased news coverage & & & $\begin{array}{l}2.72^{* *} \\
(2.28)\end{array}$ \\
\hline Constant & $\begin{array}{c}0.74 \\
(0.85)\end{array}$ & $\begin{array}{c}0.01 \\
(0.77)\end{array}$ & $\begin{array}{c}3.18^{* * *} \\
(5.06)\end{array}$ \\
\hline $\mathrm{R}^{2}$ & 0.60 & 0.39 & 0.56 \\
\hline Obs. & 18 & 18 & 18 \\
\hline
\end{tabular}

Thus, both higher underlying demand and a higher return to participating in a recent auction lead to higher participation in the current auction.

It is also of interest how much of the variation in demand could be explained by the factors that were observable by the participants in real time, i.e. before the subscription date. Therefore in the following specification we replace the unobservable (to auction participants) characteristics of the simultaneous fixed price tranche with a news coverage variable $^{49}$ (Equation 3):

$$
N_{A i}=\alpha_{0}+\alpha_{1} \Delta N E W S_{i}+\alpha_{2} r_{i, l a g 90 d}^{p}+u_{i}
$$

where:

- $\triangle N E W S_{i}$ is a dummy variable equal to 1 if the current IPO receives more news coverage $\mathrm{e}^{50}$ than the median of all the past auctions, and 0 otherwise

- $r_{i, \text { lag } 90 d}^{p}$ is the cumulative 90-day return on an equally weighted buy-and-hold portfolio of shares offered in the past 4 auctions, purchased at the tender price ${ }^{51}$, on the last business day prior to the day of subscription

It is easy to see that these real-time variables explain somewhat over half of the variation in participation $\left(R^{2}=\right.$ $56 \%$ ), again suggesting that return-chasing was taking place. Again, the coefficient on recent auction return is positive and significant at the $1 \%$ level.

While a higher participation rate in the auction is positively related to a higher auction clearing price, the higher price may be "rational", reflecting a higher intrinsic value of the issue over and above that reflected in the fixed price

\footnotetext{
${ }^{49}$ See Liu, Sherman and Zhang (2009) for analysis of the role of media coverage in IPOs.

${ }^{50}$ Measured by the number of articles that mention the IPO in Singapore business press in the 4 weeks before the subscription date

${ }^{51}$ Green line in Figure 8
} 
(and over and above the higher value reflected in fixed price tranche demand). This model predicts that when the intrinsic value of the offering is higher, both the auction clearing price and the initial return to winning bidders will be higher. It is therefore important to further investigate whether noise bidders adversely affected the environment.

\subsubsection{Bid Distribution and Future Returns}

One reason for a high clearing price is naturally a high realization of the share value. Another possible reason for such results may be the presence of free-riders: bidders who do not engage in price discovery but instead name a very high price in order to obtain an allocation. In an asymmetric equilibrium with such free-riders (whether anticipated or unanticipated) the distribution of bids will be mixed: the free-riders would bid high regardless of the underlying value, and the other bidders would bid according to their signals.

Cornelli et al. (2006) note that "in the case of IPOs, Ritter and Welch (2002) conjecture that overenthusiasm among retail investors may explain high first-day returns and low long-run returns. However, the extent to which the presence of irrational investors (motivated by "investor sentiment") can account for these phenomena is controversial, not least because of the difficulty in empirically identifying the demand curves of different investor groups". This difficulty presents a problem for us as well, since due to the multiple censoring of our dataset it is not possible for us to directly observe individual bids. However in what follows we present several quantitative results that seem to confirm the presence of naive investors'.

The number of bid ranges in our bid data and their breakpoints are auction-specific and do not allow for direct comparison between auctions. However, in presence of free-riders there should be aggregate effects: namely, their presence should increase the variance of the bid distribution and create positive skewness.

On the other hand, a high mean bid can be a signal of either high underlying value, or free-rider presence, or both. Therefore, controlling for the mean, we would expect free-riders to drive up auction prices relative to the underlying value, and potentially cause future negative returns. In line with prior reasoning, we would also expect free-riders to be more prevalent among smaller individual bidders ${ }^{52}$.

We use a two-step estimation procedure: first, we approximate the bid distribution in each auction by a separate lognormal distribution. This distribution choice allows us to capture changes both in the mean (potentially attributed to higher underlying value and overall, rational or irrational, level of excitement about the issue ) and in the skewness and variance (which both positively depend on the same parameter $\sigma$ ). In addition, these parameters, unlike range statistics, can be compared across auctions.

We use maximum likelihood to estimate the bid distribution parameters:

$$
\left(\hat{\mu}_{t}, \hat{\sigma}_{t}\right)=\underset{\mu, \sigma}{\operatorname{argmax}} \prod_{j=1}^{J_{t}}\left(F\left(\bar{b}_{j t} \mid \mu, \sigma\right)-F\left(\underline{b}_{j t} \mid \mu, \sigma\right)\right)^{n_{j t}}
$$

where the observed values $J_{t}, b_{j t}, n_{j t}$ are as described in Section 5.2.1.

Figure 10 shows the estimated $\mu$ and $\sigma$ for the applications distribution in the 18 auctions for which we have sufficient data ${ }^{53}$. As one can see, most losses characterize auctions with either a high $\mu$, or a high $\sigma$, or both, which is a picture that one would observe in presence of a large number of bidders who do not engage in price discovery.

Table 4, Panel A illustrates the relationship between the parameters of the applications distribution and future returns. Given the small sample size, a robust version of the estimation is presented in Table 4, Panel B, showing similar results. We can see from these tables that either a high $\mu$, or a high $\sigma$, or both, are significantly negatively related to one year returns on the offerings, as one would expect if the auction price and initial demand are influenced by a large number of bidders who do not engage in price discovery.

One last piece of evidence of the presence of free riders in our data is the analysis of the very highest bids. If a bid is so high that it seems implausible as a genuine result of careful analysis, the more likely explanation is free

\footnotetext{
${ }^{52}$ For IPO auctions in Taiwan, Chiang et al. (2009a) find that institutional investors are informed and bidding optimally, but that retail investors are return-chasing and following suboptimal bidding strategies. Chiang et al. (2009b) find further evidence that retail (but not institutional) investors in Taiwan's IPO auctions suffer from nave reinforcement learning, while Degeorge et al. (Forthcoming) find evidence of free riding and possible return-chasing by retail investors in U.S. IPO auctions.

${ }^{53}$ Since two auctions were undersubscribed, we are not able to estimate the bid distribution shape there. However we note that both of these auctions produced positive returns ( $48.3 \%$ in case of Sunright and $6.4 \%$ for LiangHuat Aluminum), and their undersubscription implies either a low $\mu$, or low $\sigma$, or both, so we consider our results to be conservative
} 
Figure 10: Applications Distribution and IPO Returns

Returns are market-adjusted (using STIC index); 1 year from tender. Circle area proportional to absolute return; red filled circles represent losses; blue crossed circles represent gains.

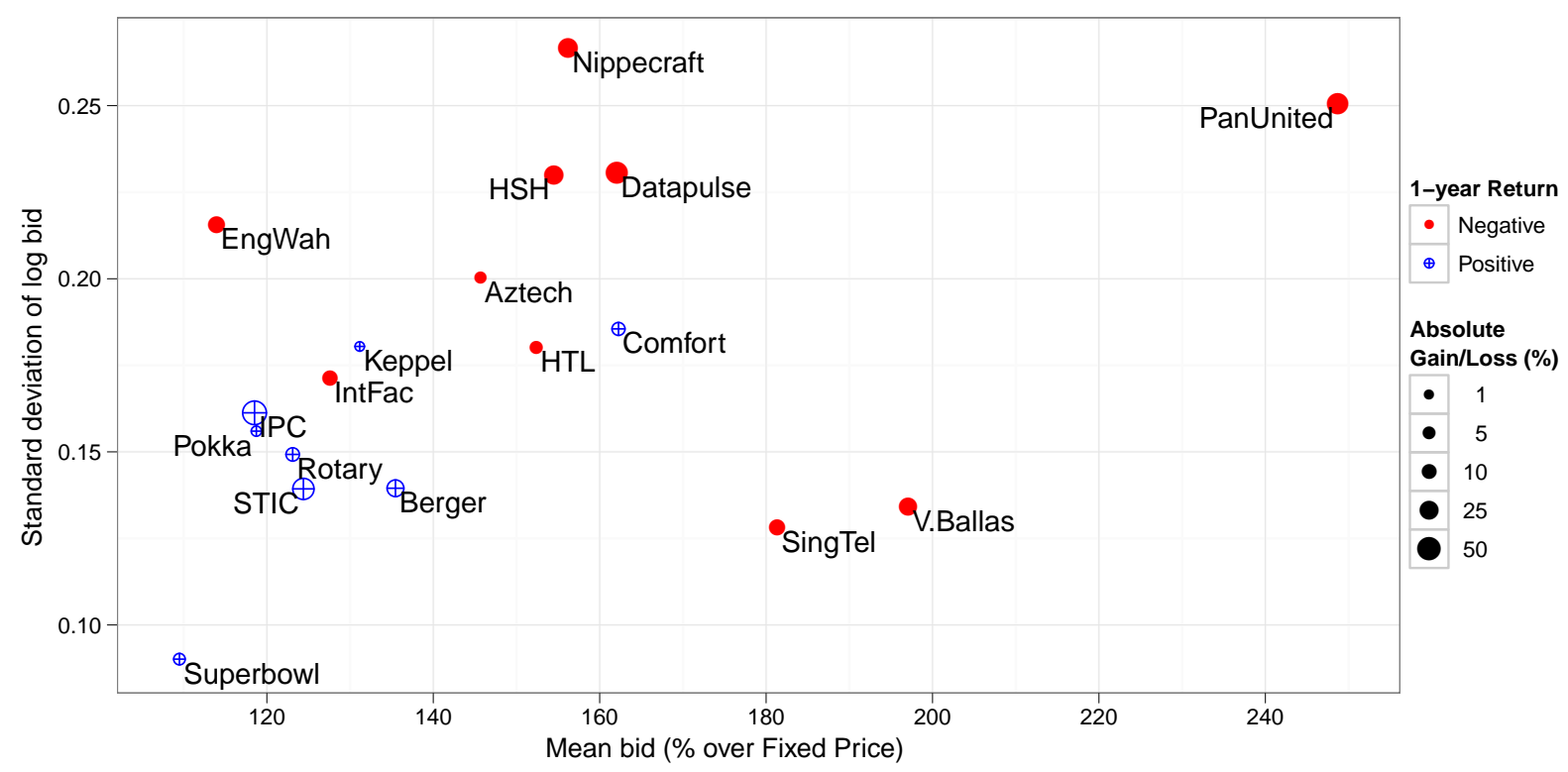

Table 4: Applications Distribution and IPO Returns

Regressions of gross returns to investors who get in and out of a position at different points in time on estimated parameters of the distribution of bids in the IPO auction. Returns are between the points listed, which are (FIX: fixed price tranche, AUC: auction clearing price, 1D: first trading day close, 1Y: last close in the first year of trading), market-adjusted where relevant: e.g. (FIX, AUC) is the auction premium, and (1D,1Y) is the market-adjusted return from the first day to the first year close. $\sigma$ and $\mu$ are the estimated parameters of the fitted lognormal distribution. Panel A shows results from a regular least squares regression (robust variance estimates are used). Panel B reports coefficients from robust regressions that reduce the impact of outliers (see Hamilton (1992) for a detailed description).

\begin{tabular}{|c|c|c|c|c|c|c|}
\hline & (FIX, AUC) & $(\mathrm{FIX}, 1 \mathrm{D})$ & $(\mathrm{FIX}, 1 \mathrm{Y})$ & $(\mathrm{AUC}, 1 \mathrm{D})$ & $(\mathrm{AUC}, 1 \mathrm{Y})$ & $(1 \mathrm{D}, 1 \mathrm{Y})$ \\
\hline \multicolumn{7}{|c|}{ Panel A: Least Squares Estimates } \\
\hline \multirow[t]{2}{*}{$\hat{\sigma}_{N}$} & -0.536 & -0.270 & $-3.289 * *$ & 0.171 & $-2.179 * *$ & $-2.285 * *$ \\
\hline & $(-0.76)$ & $(-0.25)$ & $(-2.60)$ & $(0.32)$ & $(-2.62)$ & $(-2.86)$ \\
\hline \multirow{2}{*}{$\hat{\mu}_{N}$} & $1.269 * * *$ & $1.237 * * *$ & $0.385^{*}$ & -0.0129 & $-0.486 * *$ & $-0.451 * *$ \\
\hline & $(14.85)$ & $(7.93)$ & $(1.77)$ & $(-0.10)$ & $(-2.48)$ & $(-2.65)$ \\
\hline \multirow[t]{2}{*}{ Constant } & 0.0145 & 0.0136 & $0.715 * *$ & 0.000676 & $0.509 * *$ & $0.495 * * *$ \\
\hline & $(0.13)$ & $(0.08)$ & $(2.67)$ & $(0.01)$ & $(2.80)$ & $(3.27)$ \\
\hline $\mathrm{R}^{2}$ & 0.866 & 0.721 & 0.298 & 0.006 & 0.502 & 0.571 \\
\hline Obs. & 18 & 18 & 18 & 18 & 18 & 18 \\
\hline \multicolumn{7}{|c|}{ Panel B: Robust Estimates } \\
\hline \multirow{2}{*}{$\hat{\sigma}_{N}$} & -0.478 & -0.129 & $-3.077^{*}$ & 0.123 & $-2.088^{* *}$ & $-2.244 * *$ \\
\hline & $(-0.72)$ & $(-0.12)$ & $(-2.08)$ & $(0.16)$ & $(-2.19)$ & $(-2.32)$ \\
\hline \multirow{2}{*}{$\hat{\mu}_{N}$} & $1.271 * * *$ & $1.226 * * *$ & 0.435 & -0.00493 & $-0.385 *$ & $-0.438^{*}$ \\
\hline & $(8.51)$ & $(5.17)$ & $(1.31)$ & $(-0.03)$ & $(-1.80)$ & $(-2.03)$ \\
\hline \multirow[t]{2}{*}{ Constant } & 0.00306 & -0.00910 & $0.639 * *$ & -0.00856 & $0.433 * *$ & $0.480 * *$ \\
\hline & $(0.03)$ & $(-0.05)$ & $(2.51)$ & $(-0.07)$ & $(2.65)$ & $(2.90)$ \\
\hline $\mathrm{R}^{2}$ & 0.841 & 0.670 & 0.237 & 0.002 & 0.458 & 0.501 \\
\hline Obs. & 18 & 18 & 18 & 18 & 18 & 18 \\
\hline
\end{tabular}


riding, and thus we look for excessively high bids in our data. In four of our twenty auctions, the highest bids were more than $1,000 \%$ of the reservation price. The highest bid was 1,153\% (817\%) of the reservation price (clearing price) for STIC, $1,200 \%$ (1,182\%) for Eng Wah, 1,700\% (1,000\%) for Hwa Tat Lee Holdings and 5,000\% $(2,778 \%)$ for Singapore Telecom. In the case of Singapore Telecom, the reservation price of $\$ 2.00$ translated to a prospective price-earnings (PE) multiple of 27 times. The highest bid was 50 times this, implying a PE of 1,350 times for a mature company in an established industry. This is clear evidence of the presence of at least some free riders, while our earlier analysis indicates that there were sufficient numbers of such investors to affect the auction price.

\subsection{Lessons from Treasury Auctions}

The auction method is old and well established, and has been particularly successful for the largest security issue markets - those for government debt, particularly US Treasury securities. Auctions have been frequently used for new preferred stock issues in the United Kingdom, particularly for government-owned utilities ${ }^{54}$. Key differences between government debt and IPOs make auctions theoretically more likely to work for these high grade debt auctions. First, Treasury auctions are held frequently at regular time intervals, with a core of regular participants. Fleming (2007) shows that, for 903 US Treasury security auctions between July 30, 2001 and December 28, 2005, 75.4\% of the securities were purchased by dealers and brokers. Although there are more than 800 financial institutions set up to bid directly in Treasury auctions, they accounted for only $0.5 \%$ of the allocations, with individuals accounting for another $0.5 \%$. Thus, Treasury auctions have a stable set of regular bidders - the 22 primary dealers that are expected to participate regularly. Moreover, close substitutes to the extremely high grade debt securities being issued are already trading actively in the market (on the when issued market, through the off the run securities, etc.), making valuation relatively easy and precise.

In spite of these advantages it took several decades for auctions to replace the fixed price method for selling Treasury bonds, even after auctions had been adopted for US Treasury bills. Garbade (2004) provides a detailed analysis of this process, noting in particular how back in 1959 the Secretary of the Treasury Robert Anderson in his testimony before the Joint Economic Committee defended the fixed price method, stating that "many of the small banks, corporations, and individuals... did not have the professional capacity to bid in an auction. Lacking professional expertise, they were liable to either bid too high and pay too much or bid too low and be shut out, and therefore were likely to avoid note and bond auctions altogether". Garbade (2004) further demonstrates that these worries were quite well-founded, given that the US Treasury failed in its first two attempts, in 1935 and 1963, to establish auctions for long term bond sales. The third attempt, in the early 1970s, succeeded due to the Treasury's combined "familiarity, gradualism, and willingness to improvise".

Fleming and Garbade (2002, Table 2) show that even now, of the four main securities lending facilities in the US and UK, two of the four use fixed price public offers rather than auctions. One reason for this can be that bidding is difficult even for today's sophisticated institutional investors. For example, Fleming and Garbade (2007) offer evidence that dealers frequently fail to shave their bids sufficiently in certain types of US Treasury auctions, passing up "true arbitrage opportunities" in these auctions. Fleming et al. (2005) show that they also fail to exploit certain simple mechanical profit opportunities ${ }^{55}$. On the other hand, Goldreich (2007) shows that both discriminatory and uniform price Treasury auctions lead to underpricing. Thus, even in cases when some of the easiest-to-value securities are sold to a regular set of sophisticated investors, there is evidence that the auction method has not always been preferred over fixed price methods, and that these regular bidders sometimes lack the sophistication to place optimal bids. In contrast, IPOs occur less frequently, at sporadic intervals, and their value is much more difficult to determine. Each issue is different and may attract a different set of participants, many of whom have little relevant experience. Thus, the apparent relative success of contemporary auctions for government debt does not guarantee that the auction method will also be preferred for IPOs.

As we can see, even in Treasury auctions, it took a while to make things work. The key feature is the stable number of sophisticated bidders, coupled with a noncompetitive tranche to accomodate unsophisticated bidders.

\footnotetext{
${ }^{54}$ In the six month period from Oct. 1, 1974 to March 31, 1975, all seven preferred stock issues in the UK used "Offers for Sale by Tender", i.e. auctions. The issuers were all local waterworks or water companies.

${ }^{55}$ Due to the specific price rounding scheme used in Treasury bill auctions, some bids offer strictly inferior expected profits; however many participants still bid at those suboptimal levels
} 


\section{Conclusion}

In this paper, we first established a surprising empirical regularity - that IPO auctions have been tried in at least 25 countries, and have generally been rejected in favor of other methods for bringing new equity issues to the market. IPO auctions have been used for issues of all sizes, from very small to very large. The auction methods used have varied, yet the outcomes have been surprisingly consistent: When issuers have been given a choice, they have generally chosen not to use auctions once they became familiar with the method. In this sense, IPO auctions have consistently failed the market test.

We did not find support for the common explanations offered for the unpopularity of IPO auctions in the US - that issuers were reluctant to use a new, experimental method, or that underwriters pressured issuers to use a method for which they charged higher fees or were able to allocate underpriced shares. We did not find that issuers consistently preferred the method that led to the lowest initial returns. Moreover, there is little support for the popular view that auctions lead to highly accurate pricing and hence to a low mean and variance of initial returns.

In order to explain these regularities, we examined the issue of complexity. While indirect mechanisms, such as auctions, may have simple rules, this does not imply that the investors' task is in any way simple: for example, bidders must place their bids before knowing how many others will enter the auction, and those who invest time and money evaluating an offering risk being squeezed out by others who do not adequately understand the optimal bidding strategies and perhaps have no information on the value of the shares.

The optimal bid for any one participant depends on the number of other bidders, their information sets and their bidding strategies, but none of this is known at the time that bids are placed in a sealed bid auction - presenting a structural risk, which can easily exceed the uncertainty about valuation of the company itself. In other words, optimal auction bidding strategies are complicated, requiring sophistication and discipline, and mistakes by some impose costs on all bidders. Without some way to screen out "free riders" and ensure the participation of sophisticated, long term investors, IPO auctions are highly risky for both issuers and bidders.

Book building, on the other hand, requires less bidder sophistication. With book building the underwriter can act as a gatekeeper, coordinating the number and type of entrants, and setting the price and allocations only after observing all orders. At the same time, book building gives enormous discretion to the mechanism administrator (i.e. underwriter), whereas auctions are transparent with little discretion. Book building is thus vulnerable to abuse by underwriters, at the expense of issuers ${ }^{56}$. Jagannathan and Sherman (2005) propose ways to make book building more transparent and thus, effectively, closer to auctions in that sense. The optimal placement method is likely to be different from both traditional book builds, with their lack of transparency and resulting opportunities for potential abuse, and standard sealed bid auctions, with their high risk for both investors and issuers.

Standard sealed bid auctions have rigid, automatic pricing and allocation rules that do not appear to satisfy the many goals that issuers have for IPOs, based on the market test. However this does not mean that optimal auctions or more generally, transparent placement methods - cannot be designed. ${ }^{57}$ One simple change which might improve auction outcomes is to use hybrids, with retail investors allowed to participate only in the fixed price public offer tranche. This is a somewhat crude but simple and cheap way to try to limit auction participants to a relatively small, predictable number of sophisticated bidders. Retail investors would still be able to participate in hybrid IPOs through the retail tranche, but they would not be able to disrupt the price-setting process.

Although the outcomes in various countries have been surprisingly consistent in terms of which issue methods have been chosen by issuers, it is important to offer a menu of alternatives to issuers, since the best method may depend on conditions and may change over time. For example, uniform price auctions may be a better method in exuberant times, when accurate evaluation is difficult and thus not the main driver of pricing, such as with dot.coms during the internet bubble. At that time dot com stock valuations were probably driven mostly by animal spirits. The use of uniform price auctions would have allowed the offer prices to be driven up until the shares were overpriced by most estimations, leading to aftermarket price drops that would have popped the bubble earlier. Since each issue method has advantages and neither clearly dominates, only the market can tell whether there is a place for both or only

\footnotetext{
${ }^{56}$ Moreover, the Facebook IPO in 2012 shows that book building does not guarantee predictable outcomes. IPO investors face risk under any of the current offering methods.

${ }^{57}$ For example, the optimal auction in Spatt and Srivastava (1991) incorporates both pre-play communication and participation restrictions. Similarly, a dynamic auction such as that suggested by Ausubel (2002) might work better than what has been tried so far for IPOs.
} 
one of them. Having competing mechanisms available to issuers at any given point in time will be to the advantage of investors as well as issuing firms.

In summary, there have been many experiments with IPO auctions across different countries, cultures and market conditions over the last several decades. However, auctions have failed to capture sufficient market share. We offer an explanation for this, based on the complexity of optimal bidding strategies and the vulnerability of each bidder to mistakes by others. Suitably designed auctions that overcome these limitations may well be preferred over book building for bringing new equity issues to the market in the future.

\section{Appendix A. Baseline Auction Model}

Consider a simple uniform-price auction: There are $K$ lots of IPO shares offered for sale. Each lot consists of $n$ shares, where all shares have the same random, ex ante unknown value of $V$ to everyone, with a common knowledge prior $G(V)$, with $\mathrm{E} V<\infty$, which is assumed to have a positive density everywhere on a compact support $\Omega_{V} \subseteq \mathbb{R}^{+}$. There are $N$ identical bidders who compete for the allocations. Utility of a bidder who receives an allocation of $x$ shares at a price $p$ is given by $u\left(c_{0}+(V-p) x\right)$, where $u$ is a strictly increasing, concave function, and $c_{0}$ is his initial capital. Without loss of generality, we normalize $u\left(c_{0}\right)=0$. The expected value of shares and expected utility are both assumed to be finite: $\mathrm{E} V<\infty, \mathrm{E} u\left(c_{0}+(V-p) x\right)<\infty \forall p \in \Omega_{V}, 0 \leq x \leq 1$.

For expositional convenience we consider a unit-demand auction, where all $K=15$ winning bidders receive identical allocations of one lot of shares each, and all $N-K$ losing bidders receive an allocation of 0 .

We first consider the case with zero information and transaction costs. Every bidder $i, i=1 \ldots N$ receives conditionally independent, identically distributed signals $s_{i}$ about the true value $V$ :

$$
s_{i} \sim F\left(s_{i} \mid V\right)
$$

where $F\left(s_{i} \mid V\right)$ is assumed to have a finite expectation and a strictly positive density over a compact support $\Omega$. Without loss of generality, we impose a normalization $\mathrm{E} s_{i}=V$.

After observing their signals $s_{i}$, the agents submit their bids $b_{i}$ for one lot each. The agents' strategy (or bidding function) $B(s)$ is the correspondence between their signals and bids: $b_{i}=B_{i}\left(s_{i}\right)$.

The auctioneer collects bids $b=\left\{b_{1} \ldots b_{N}\right\}$, determines the clearing price and allocates one (and only one) lot of shares to every bidder whose bid is above the clearing price. An allocation without preferences and rationing implies that the auction clearing price $p \in\left[b^{(K+1)}, b^{(K)}\right]$ - i.e. $p$ lies between the bids of $K$ 'th and $(K+1)$ 'st agents ${ }^{58}$. For the sake of argument, let $p=b^{(K+1)}$. Ties are broken at random (note that when the unconditional signal distribution has no mass points and all bidders' strategies are strictly increasing in their signals, a tie is a probability zero event).

An equilibrium allocation is such that for each bidder $i$ his strategy $B_{i}$ is the optimal response to the collection of other bidders' strategies.

This model, under assumptions of symmetry ${ }^{59}$, full rationality, identical priors and common knowledge of the information structure, is analyzed in Milgrom (1981). It is useful to repeat some of the results from there, and to demonstrate their quantitative implications.

Theorem 1. The above model has a unique symmetric equilibrium, where every bidder $i$ has the same, strictly increasing bidding function $B(s)$, that solves the equation

$$
E\left\{u(V-B(s)) \mid S_{i}=s, s_{-i}^{(K)}=s\right\} \equiv 0
$$

and in the risk-neutral case $u(x)=x$ take a simple form of

$$
B(s)=E\left\{V \mid s_{i}=s, s_{-i}^{(K)}=s\right\}
$$

where $s_{-i}^{(K)}$ is the $K^{\prime}$ th highest signal of all agents other than $i$.

\footnotetext{
${ }^{58}$ Here and below, we use notation $z^{(K)}$ to denote $K^{\prime}$ th highest component of a vector $z$, and $z_{-i}$ to denote a vector with $i$ th component dropped: $z_{-i}=\left\{z_{1}, z_{2}, \ldots, z_{i-1}, z_{i+1}, \ldots, z_{N}\right\}$

${ }^{59}$ Here meaning that the bidding functions of different participants are the same: $B_{i}(\cdot) \equiv B(\cdot) \forall i$
} 


\section{Proof. See Milgrom (1981).}

In other words, agents can't do better than bid under the assumption that they have received the lowest of the winning signals. Note also that monotonicity of $B$ also implies that $B$ is strictly positive everywhere in the interior of $\Omega$ : in other words all $N$ bidders submit bids in equilibrium.

As the number of bidders increases, the auction price asymptotically approaches the true value $V$, in other words, the auction discount approaches zero (see Pesendorfer and Swinkels (1997) for a detailed analysis and a discussion of the relevant assumptions).

In the numerical examples we examine, unless otherwise mentioned, we consider a hypothetical IPO with an ex ante expected value of $\$ 15$ million, split into $\mathrm{K}=15$ blocks of 100,000 shares each, where the share value $V$ has a lognormal distribution with $E(V)=\$ 10$, and standard deviation of $\log (V)=0.30$ (i.e. corresponding to a standard deviation of $30 \%$ for the continuously compounded rate of return to an uninformed investor in the stock). The private signal $s_{i}$ is centered at the actual share value, conditional on which it is also lognormal with a standard deviation of $30 \%$. The bidder pool consists of $N$ potentially informed biddersIn addition to the risk-neutral case, in order to investigate the effects of bidders' risk aversion, we will also consider constant relative risk aversion bidder utility $u(c)=\frac{c^{1-A}}{1-A}$, with initial capital of $c_{0}$ calibrated to $\$ 30$ million for each bidder.

\section{Appendix B. Evaluating Auctions}

To find equilibrium bidding functions in the calibration exercises, we numerically solved equation (A.2) in the symmetric case, and its suitably adjusted modifications in the other cases. The lognormal signal distribution was approximated with a truncated lognormal on a range $\left.[\underline{S}, \bar{S}]=e^{\mu-10 \sigma}, e^{\mu+10 \sigma}\right]$. Monte-Carlo integration with 100,000 draws of $\left(V, s_{-i}\right)$ was used to compute the conditional expectations; in order to properly account for low tail probabilities and avoid underflow we used importance sampling ${ }^{60}$. In risk-neutral cases such as (A.3) the optimal bids were computed directly; in the general case, a two-step procedure was used: in the first step, a Monte-Carlo sample was generated; in the second, an iterative zero-finding algorithm ${ }^{61}$ was used to find the optimal bidding function conditional on the sample. We found that the solution is very robust with respect to the Monte-Carlo sample selection.

In order to improve computational performance, integration was used to evaluate the bidding functions on a grid of values spanning $[\underline{S}, \bar{S}]$, with piecewise cubic Hermite polynomials ${ }^{62}$ used to interpolate the functions between the grid points.

Given bidding functions computed as above, various outcomes such as expected profits were also computed using Monte-Carlo simulation with 1,000,000 iterations.

\section{Appendix C. Details on International IPO Experience}

\section{Appendix C.1. High first day gains}

- Tenaga Nasional, Malaysia, May 1992,34\%: Malaysia's first auction was a hybrid discriminatory auction/public offer. Initial returns for winning bids ranged from $23 \%$ to $34 \%$, even though the market-clearing price in the auction was almost $46 \%$ above the 4.50 ringgit reservation price. The initial return for the public offer was $94 \%$.

- DDI (an affiliate of Kyocera), Japan, September 1993, 49\%: Bids went as high as ¥6.02 million/share. The offer price was set at $¥ 3.7$ million, because most successful bids were concentrated at that price. The first day’s close was at $¥ 5.5$ million.

- East Japan Railway, Japan, October 1993, 58\%: JR East soared 70\% above the market-clearing price the first day, only to drop back down to around the $¥ 370,000$ /share offer price within two days. Winning bids ranged from $¥ 352,000$ to $¥ 623,000$, so the highest bidders were still out of the money when the stock closed at $¥ 600,000$ the first day.

\footnotetext{
${ }^{60}$ See, for example, Judd (1998).

${ }^{61}$ See Forsythe et al. (1977)

${ }^{62}$ Selected to ensure monotonicity of the interpolating function, see Fritsch and Carlson (1980)
} 
- Petron, the Philippines, Sept. 1994, 63\%: Hybrid discriminatory auction/public offer. The first day's closing price was $63 \%$ above the lowest winning bid, $23 \%$ above even the highest bid, $39 \%$ above the highest foreign bid and $136 \%$ above the reservation price. The fixed price tranche drew 459,133 subscribers.

- Andover.net, US, December, 1999, 252.1\%: The offering was priced at \$18 even though the clearing price was $\$ 24$, reportedly to avoid any delay. The first day's closing price was $164 \%$ above even the auction clearing price.

- El Al, Israel, June 2003, 40\%: Demand was low in the auction - they sold fewer shares than expected, all priced at the minimum bid. The shares began trading on the Tel Aviv Stock Exchange just two days later, closing up $40 \%$ the first day and up a total of $112 \%$ by the end of the second trading day.

\section{Appendix C.2. High first day losses}

- Japan Telecom, September 1994, down $14.5 \%$ from the weighted average bid price of $¥ 5.44$ million/share on the first day, and down another $10 \%$ by the end of the week: The lowest successful bid was $¥ 5.22$ million, but the public offer price (set after the auction) was $¥ 4.7$ million, showing that the auction bids were considered unrealistic. The weighted average bid price gave the company a P/E of 219 times prospective earnings, in a mature telecom market.

- Japan Tobacco, October 1994, down 23.5\% the first day, and it kept falling from there: The auction had been unusually enthusiastic, with a weighted average winning bid of $¥ 1.438$ million/share for shares that institutional investors valued at no more than ¥800,000. Successful bids ranged from $¥ 1.362$ million to $¥ 2.11$ million. It closed the first day at $¥ 1.10$ million, and the second day at $¥ 1.06$ million (down more than $26 \%$ ). After 2 weeks of trading, it was at $¥ 956,000$, down $33.5 \%$. The highest bidders lost almost $48 \%$ the first day. $41 \%$ of the shares were never sold.

- Global Securities (Global Menkul Degerler A.S.), Turkey, May 1995, down 11\% the first hour: The reservation price was set at TL6,000 per share, but bids went as high as TL100,000. The auction price was set at TL9,750, a $62.5 \%$ premium. The price fell by $56.1 \%$ (giving a market-adjusted return of $-60.5 \%$ ) over the first three months. 


\begin{tabular}{|c|c|c|c|c|c|}
\hline Country & Argentina & Australia & Austria & Bangladesh & Barbados \\
\hline Main sources: & 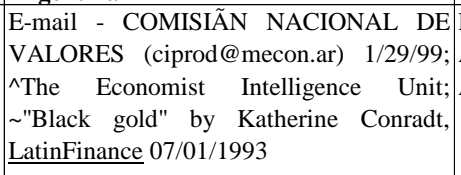 & $\begin{array}{l}\text { Euroweek April } 1998 \text { Supplement, } \\
\text { Australia: A Special Report; ^Letter } \\
\text { Australian Stock Exchange, } 23 \text { April } 1996\end{array}$ & $\begin{array}{l}\text { Letter - Wiener Borse (Vienna Stock } \\
\text { Exchange), 14 June 1996 }\end{array}$ & $\begin{array}{l}\text { Press } \quad \text { Release, Chittagong } \\
\text { Exchange, Sept. 14, } 2008\end{array}$ & $\begin{array}{l}\text { Letter - Securities Exchange of Barbados, } \\
8 / 28 / 97\end{array}$ \\
\hline Does gov't restrict method? & No & No & No & Yes & \\
\hline Most common method & ^Hybrid Book Building & Hybrid Book Building & Hybrid Book Building & $\begin{array}{l}\text { Public Offer (only method allowed until } \\
\text { recently) }\end{array}$ & Public Offer \\
\hline * Public offer (Fixed price) & & Have virtually disappeared & Yes - Usually for small firms & Yes & Yes - only method used \\
\hline Advance payment? & & ${ }^{\wedge}$ Yes & No & & Yes \\
\hline * Book Building & Yes & Yes - "the norm" & $\begin{array}{l}\text { Yes - Traditional for large IPOs, such as } \\
\text { privatizations }\end{array}$ & & \\
\hline Is it gaining popularity? & & Already dominant & Yes & & \\
\hline Whenjwas it first used? & $\begin{array}{|lrr|}\text { 1993 for } & \text { Yacimientos } & \text { Petroliferos } \\
\text { Fiscales } & & \\
\end{array}$ & 1992 & & & \\
\hline * Tender/Auction & Tried in 1991-92, then abandoned & Tried briefly in 1999 (see below) & No & Allowed, beginning 2009 & \\
\hline \multicolumn{6}{|l|}{ Discriminatory/uniform } \\
\hline Hybrid Methods? & $\begin{array}{l}\text { Yes, at least for privatizations - Hybrid } \\
\text { Book Building/Public Offer }\end{array}$ & $\begin{array}{l}\text { Yes - "open priced book building } \\
\text { approach" widespread }\end{array}$ & $\begin{array}{l}\text { Yes - book building for larger issues } \\
\text { includes an open pricing public offer } \\
\text { tranche }\end{array}$ & Yes - auction with fixed price public offer & \\
\hline General notes: & $\begin{array}{l}\text { According to the Economist Intelligence } \\
\text { Unit, March 9, 2000, listings on the } \\
\text { Buenos Aries Stock Exchange have been } \\
\text { declining for years. 'Dutch' auctions } \\
\text { were used for a few offerings including the } \\
1991 \text { Telefonica and } 1992 \text { Telecom } \\
\text { privatizations, but the overpricing of } \\
\text { Telecom led a market crash. So, in } \\
1993 \text { for Yacimientos Petroliferos } \\
\text { Fiscales, book building was used for the } \\
\text { first time, with great success. }\end{array}$ & $\begin{array}{l}\text { Two offerings by Ord Minnet's eCapital in } \\
1999 \text { were called bookbuilds but were } \\
\text { online auctions, with updated weighted } \\
\text { average bid prices posted twice a day and } \\
\text { people allowed to change their bids any } \\
\text { time during the auction. The open priced } \\
\text { bookbuilding approach was pioneered in } \\
\text { Australia by the then Potter Warburg in } \\
\text { the } 1992 \text { Government Insurance Offices } \\
\text { flotation. "Short form" retail prospectus } \\
\text { first used in Nov. 1998. According to } \\
\text { Asian Business, Sep. 2000, "Enter e- } \\
\text { IPOs", scripless "e-IPO" methods already } \\
\text { in use. }\end{array}$ & $\begin{array}{l}\text { Public offer procedures are different from } \\
\text { listing offer procedures \& are governed by } \\
\text { different EU directives. IPOs are possible } \\
\text { without listing. Subscription periods vary } \\
\text { widely - up to seven weeks for smaller } \\
\text { IPOs; } 2-3 \text { days for internationally } \\
\text { announced, well-publicized offerings, with } \\
\text { a possibility of early closing; occasionally, } \\
\text { privatizations close only after a few hours. } \\
\text { It is possible that the foreign tranches of } \\
\text { some large IPOs have included auction- } \\
\text { type elements }\end{array}$ & $\begin{array}{l}\text { In } 2009 \text {, Bangladesh began allowing two } \\
\text { stage sequential hybrid offerings where } \\
\text { prices are set through the "true Dutch } \\
\text { auction" method. Only institutional } \\
\text { investors are allowed to bid in the auction. } \\
\text { The subsequent fixed price public offer } \\
\text { opens at least } 25 \text { days after the auction } \\
\text { price is determined. This method is } \\
\text { officially called "book building", but the } \\
\text { offer price is automatically set at the } \\
\text { market-clearing price and allocations are } \\
\text { pro-rata. }\end{array}$ & $\begin{array}{l}\text { There were } 3 \text { IPOs in 1994, none in } 1995 \\
\text { and } 2 \text { in 1996. 1994: Barbados Farms } \\
\text { Ltd., ST. James Beach Hotels Ltd. and } \\
\text { CIBC W.I. Holdings Ltd.; 1996: Almond } \\
\text { Beach Resorts Inc. and Life of Barbados } \\
\text { Ltd. } \\
\end{array}$ \\
\hline
\end{tabular}




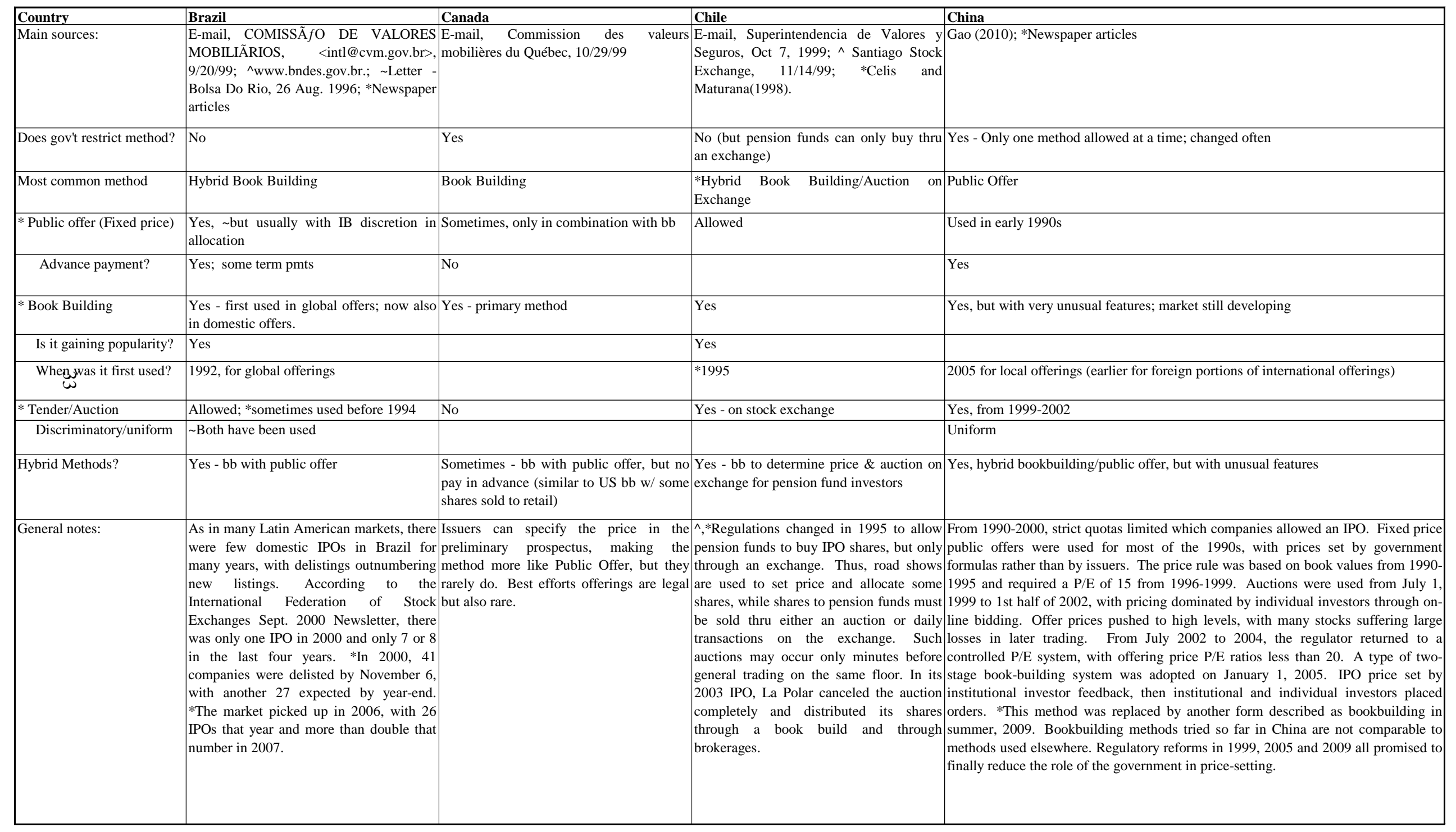




\begin{tabular}{|c|c|c|c|c|c|}
\hline \multirow{4}{*}{\begin{tabular}{|l|} 
Country \\
Main sources:
\end{tabular}} & \multirow{2}{*}{\begin{tabular}{|l|} 
Czech Republic \\
E-mail the Crech Securities Commission \\
\end{tabular}} & Egypt & \multirow{2}{*}{\begin{tabular}{|l} 
Finland \\
E-mail, Financial Supervision Authority of
\end{tabular}} & \multicolumn{2}{|r|}{ Germany } \\
\hline & & Newspaper articles in Financial Times, & & E-mail - Listing Division, Paris Bourse & E-mail - BAWe (Bundesaufsichtsamt fur \\
\hline & 10/26/99 APrague Stock Exchange & Euromoney, International Herald Tribune, & Finland, 11/29/99; ^ Letter - Mandatum \& & SBF SA, $7 / 28 / 2000, \wedge^{\wedge}$ Derrien and & den Wertpapierhandl) $2 / 2 / 2000$ \\
\hline & Website, www.pse.cz & Associated Press Worldstream & $\begin{array}{l}\text { Co., } 30 \text { May 1996; Also see web page } \\
\text { www.rata.bof.fi }\end{array}$ & Womack (1999) & 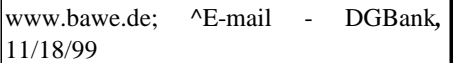 \\
\hline Does gov't restrict method? & Yes & & No & Yes, but many options & No \\
\hline Most common method & ${ }^{\wedge}$ Hybrid Book Building/Public Offer & Fixed Price Public Offer & Hybrid Book Building/Public Offer & Hybrid Book Building/Public Offer & Book Building \\
\hline * Public offer (Fixed price) & $\begin{array}{l}\text { Yes - "must be used for first round" (for } \\
\text { voucher privatizations) }\end{array}$ & Yes - primary method & Yes & $\begin{array}{l}\text { Yes - Offre a Prix Ferme (OPF) or Open } \\
\text { Price Offer (OPO; only for hybrids) }\end{array}$ & $\begin{array}{|lll|}\text { Yes } \quad-\quad \text { Offentliches } & \text { Angebot } & \wedge \text { now } \\
\text { superseded by bb } & & \\
\end{array}$ \\
\hline Advance payment? & Yes - 30\% (installment) & Yes & Usually, for retail investors & $\begin{array}{l}\text { No, but need corresponding cash in } \\
\text { account }\end{array}$ & No \\
\hline * Book Building & ${ }^{\wedge}$ Yes, since 2004 & Yes, at least for some large offers & Yes & $\begin{array}{l}\text { Yes - Placement Garanti (PG), only as } \\
\text { hybrid }\end{array}$ & Yes -^"used for almost every IPO" \\
\hline Is it gaining popularity? & & & Yes & Yes & Yes \\
\hline When,was it first used? & & & & 1993 & 1995 \\
\hline * Tender/Auction & possible for second round, if number of & & Allowed & Rare - Offre a Prix Minimal (OPM) & No \\
\hline Discriminatory/uniform & $\begin{array}{l}\text { "single, but rules of auction can be } \\
\text { different" }\end{array}$ & & Uniform price & Uniform price & \\
\hline Hybrid Methods? & $\begin{array}{l}\text { Possible to have auction/public offer, but } \\
\text { not common }\end{array}$ & Yes - bb with public offer & $\begin{array}{l}\text { Yes - bb for institutional, public offer for } \\
\text { retail at price set by bb - "most common } \\
\text { over last } 18 \text { months" (to Nov., 1999) }\end{array}$ & $\begin{array}{l}\text { Yes - All book building must be combined } \\
\text { with either OPF or OPO }\end{array}$ & $\begin{array}{l}\text { Yes - "lottery" methods often used for } \\
\text { retail tranche allocations; IB discretion }\end{array}$ \\
\hline General notes: & $\begin{array}{l}\text { All Czechoslovakian companies } \\
\text { nationalized in } 1948 \text { \& owned by the state } \\
\text { from } 1948 \text { - 1990. Two waves of voucher } \\
\text { privatizations - in 1993 \& } 1994 . \\
\text { Private co. IPOs on Prague Stock } \\
\text { Exchange began after Czech Republic } \\
\text { entered European Union: Zentiva, 2004; } \\
\text { ECM Real Estate \& Pegas Nonwovens, } \\
\text { 2006; AAA Auto, 2007; New World } \\
\text { Resources (NWR), 2008, through a large } \\
\text { joint listing in Prague, London and } \\
\text { Warsaw. Prague SE less active than } \\
\text { Warsaw \& Budapest Exchanges. Retail } \\
\text { allowed to participate. }\end{array}$ & $\begin{array}{l}\text { The Cairo Stock Exchange was dominated } \\
\text { by privatizations for much of the } 1990 \text { s } \\
\text { and saw the first truly private company } \\
\text { IPO in 1997, with Cairo Precision } \\
\text { Industries. Fixed price public offer with } \\
\text { pay in advance was the only method until } \\
2000 \text {. Orascom, June } 2000 \text {, was the first } \\
\text { hybrid bookbuild/public offer. After } \\
\text { Orascom, there were no IPOs at all until } \\
\text { the Dec. } 2004 \text { IPO of Lecico, which was } \\
\text { also a hybrid bookbuild, as was Egypt } \\
\text { Telecom in Dec. 2005. }\end{array}$ & $\begin{array}{l}\text { IPOs governed by Securities Market Act } \\
495 / 1989 \text {. Must set preliminary price } \\
\text { range in prospectus. Usually, price for all } \\
\text { shares set by bb, but w/ price ceiling for } \\
\text { retail tranche (or else retail investors must } \\
\text { have at least one day to cancel orders after } \\
\text { price set). Investors in public offer } \\
\text { sometimes get interest on subscription } \\
\text { funds, depending on when subscription } \\
\text { was paid. Price for employees usually } \\
10 \% \text { lower than for retail, for tax reasons. } \\
\text { Issuer must at least estimate \# of shares } \\
\text { for each tranche in prospectus. }\end{array}$ & $\begin{array}{l}\text { Open Price Offer (OPO) introduced in } \\
1999 \text { because sequential hybrid PG/OPF } \\
\text { required setting price too far in advance. } \\
\text { With hybrid PG/OPO, price is not set until } \\
\text { day of listing, *as in hybrid bookbuilds in } \\
\text { most countries. Derrien \& } \\
\text { Womack(2003) showed bookbuild } \\
\text { problems due to time delay of PG/OPF. } \\
\text { When simultaneous hybrid bookbuilding } \\
\text { (PG/OPO) allowed, auctions dried up } \\
\text { except for two in 2005: Cafom on Second } \\
\text { Marche in January and MG International } \\
\text { on Alternext in June. Auctions died out } \\
\text { later on unregulated Marche Libre (Free } \\
\text { Market). }\end{array}$ & $\begin{array}{l}\text { "In recent time the book building } \\
\text { technique has been used for nearly all } \\
\text { IPOs, local offers and international offers." } \\
\text { "Sometimes retail investors are preferred } \\
\text { for privatizations or larger transactions. } \\
\text { For example, the issuer offers discounts } \\
\text { for orders given early within the } \\
\text { subscription period." ^A joint statement } \\
\text { was made by the larger issuing houses, } \\
\text { stating they would not use the auction } \\
\text { method. }\end{array}$ \\
\hline
\end{tabular}




\begin{tabular}{|c|c|c|c|c|c|}
\hline Country & Hong Kong & Hungary & India & Indonesia & Ireland \\
\hline Main sources: & $\begin{array}{l}\text { General sources; ^Asian Business, Sep. } \\
\text { 2000, "Enter e-IPOs" }\end{array}$ & $\begin{array}{l}\text { E-mail, Hungarian Banking \& Capital } \\
\text { Market Supervision, 11/30/99 }\end{array}$ & $\begin{array}{l}\text { SEBI (Securities \& Exchange Board of } \\
\text { India) web page, www.sebi.gov.in; } \\
\text { *Bombay Stock Exchange, 4/13/96; } \\
\text { ^Assoc. of Merchant Bankers of India, } \\
\text { 5/27/96. }\end{array}$ & $\begin{array}{l}\text { Indonesian Capital Market Supervisory } \\
\text { Agency (BAPEPAM), 9/24/99; www. } \\
\text { bapepam.go.id; ^"IBRA sets BCA share } \\
\text { price at Rp 1,400", The Jakarta Post, } \\
\text { Thurs. 05/11/2000. }\end{array}$ & $\begin{array}{l}\text { E-mail, Irish Stock Exchange, 9/15/99; } \\
\text { Newspaper articles }\end{array}$ \\
\hline Does gov't restrict method? & & No & Yes & Yes & No \\
\hline Most common method & 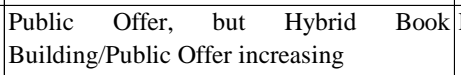 & Hybrid Book Building/Public Offer & Auction; was Public Offer & & Hybrid Book Building \\
\hline * Public offer (Fixed price) & Yes & Yes & Yes $-^{*}, \wedge$ most common in $1990 \mathrm{~s}$ & Yes - only method allowed before 2000 & Used mainly for larger offerings \\
\hline Advance payment? & Yes & Yes - minimum $10 \%$ installment & * Usually; installments common. & Yes & Yes \\
\hline * Book Building & Yes & Yes & No - allowed in 1990s, banned in 2005 & Introduced in 2000 & $\begin{array}{l}\text { Yes (traditionally called placing, but the } \\
\text { methods are similar) }\end{array}$ \\
\hline Is it gaining popularity? & Yes & Yes & & & \\
\hline When,was it first used? & 1994 & 1994 & 1999 & & \\
\hline * Tender/Auction & Allowed since 1993 but never used & Allowed, not used & Yes, since 2005 & No & Very rare. \\
\hline Discriminatory/uniform & & & Uniform price & & \\
\hline Hybrid Methods? & $\begin{array}{l}\text { Yes - bb only with public offer; } \\
\text { simultaneous }\end{array}$ & $\begin{array}{l}\text { Yes - bb/public offer is the most common } \\
\text { method }\end{array}$ & $\begin{array}{l}\text { Yes - originally sequential hybrids, which } \\
\text { led to timing problems; simultaneous } \\
\text { hybrids later allowed }\end{array}$ & $\begin{array}{l}\text { Yes - sequential hybrid, with fixed price } \\
\text { public offer after bookbuild }\end{array}$ & $\begin{array}{l}\text { Yes - bb/placing with public offer. } \\
\text { Simultaneous. }\end{array}$ \\
\hline General notes: & $\begin{array}{l}\text { In hybrids, amount initially allocated to } \\
\text { retail investors is typically only } 10-15 \% \text {, } \\
\text { but clawbacks can raise the \% to } 30-50 \% \\
\text { if retail demand high. Often a third, } \\
\text { private placement tranche for "strategic } \\
\text { investors". Overallotment options } \\
\text { common. Grey market trading begins } \\
\text { during, or even prior to, the offer period. } \\
\text { Substantial interest may be earned on } \\
\text { subscription funds when demand is high. } \\
\text { ^Hong Kong's Securities and Futures } \\
\text { Commission has released detailed } \\
\text { guidelines for electronic initial public } \\
\text { offerings (e-IPOs). }\end{array}$ & $\begin{array}{l}\text { Greenshoe options common. Current SHs } \\
\text { may have right of priority. Otherwise, } \\
\text { shares in public offer allocated under "the } \\
\text { principle of card dealing, or subscription- } \\
\text { proportionate allocation". BB used for the } \\
\text { majority of institutional allocations } \\
\text { (private placements). Public offer was } \\
\text { main method in 1990-94. BB used 1st for } \\
\text { large, international transactions. Public } \\
\text { offer in hybrids has a fixed price range or } \\
\text { maximum price, so final price can be set } \\
\text { by bb. Note: Budapest Stock Exchange } \\
\text { (as well as Warsaw) most active in region. }\end{array}$ & $\begin{array}{l}\text { Bookbuilding (BB) allowed but heavily } \\
\text { restricted in 1995. Rules relaxed July, } \\
1999 \text {, \& BB became more popular. Sept. } \\
19,2005 \text {, the regulator (SEBI) banned } \\
\text { discretionary allocations in SEBI Circular } \\
\# \text { SEBI/CFD/DIL/DIP/16/2005/19/9, } \\
\text { changing institutional investor allocations } \\
\text { to "proportionate". Since 2005, only } \\
\text { hybrid auctions \& pure public offers } \\
\text { allowed, but upper limits for auctions } \\
\text { make many of them effectively fixed price. } \\
\text { Auctions may be open book, with updated } \\
\text { bidding totals posted online every } 30 \\
\text { minutes during auction. }\end{array}$ & $\begin{array}{l}\text { All IPOs fully underwritten; may list on } \\
\text { Jakarta or Surabaya Stock Exchange, or } \\
\text { both. Allocation method: Max. 40\% to } \\
\text { institutional (pro-rata); rest to retail, } \\
\text { favoring small applications (pooling basis } \\
\text { everyone gets at least } 500 \text { shares and rest } \\
\text { pro-rata; if } 500 \text { shares each is not feasible, } \\
\text { use lottery). A Indonesia nationalized } \\
\text { many banks that failed as part of the } 1998 \\
\text { Asian flu. IBRA (Indonesian Bank } \\
\text { Restructuring Agency) began hybrid } \\
\text { bookbuilds to sell banks, beginning with } \\
\text { Bank Central Asia (BCA) in 2001 }\end{array}$ & $\begin{array}{l}\text { Usual time period from day the offering } \\
\text { price is set to the day the subscription } \\
\text { period begins varies significantly - approx } \\
\text { one month but could be less or more. } \\
\text { *The number of IPOs on the Irish Stock } \\
\text { Exchange has not been high, but generally } \\
\text { the method used now is simultaneous } \\
\text { hybrid bookbuilding/public offer. }\end{array}$ \\
\hline
\end{tabular}




\begin{tabular}{|c|c|c|c|c|c|}
\hline Country & Israel & Italy & Japan & Jordan & Kenya \\
\hline Main sources: & $\begin{array}{l}\text { E-mails - Tel Aviv Stock Exchange, Feb., } \\
\text { Sept. and Oct. 1999; *Newspaper articles }\end{array}$ & $\begin{array}{l}\text { E-mail, Borsa Italiana S.p.A. 11/24/99; } \\
\text { ^Italian Stock Exchange Commission } \\
\text { (CONSOB) web page, www.consob.it }\end{array}$ & $\begin{array}{l}\text { Pettway (1999); ^Institutional Investor, } \\
\text { June 2000, "Opening Japan's Capital } \\
\text { Markets"; *Newspaper articles }\end{array}$ & $\begin{array}{l}\text { E-mail, Amman Stock Exchange, } 24 \text { June, } \\
\text { 1997; ^Amman Stock Exchange web } \\
\text { page (accessme.com/AFM). }\end{array}$ & $\begin{array}{l}\text { Fax, Capital Markets Authority, 4/3/00; } \\
\wedge \text { "Deals of the Year, 2009", The Banker, } \\
\text { May 1, } 2009\end{array}$ \\
\hline Does gov't restrict method? & Not since mid-2007 & & Yes, but several options & Yes & \\
\hline Most common method & Auctions? & Hybrid Book Building/Public Offer & Hybrid Book Building & Public Offer - only method allowed & Public Offer \\
\hline * Public offer (Fixed price) & Yes & Yes - only for retail & Yes, but w/ allocation discretion & & Yes \\
\hline Advance payment? & No & No & & Yes & Yes \\
\hline * Book Building & Allowed since mid-2007 & Yes - only for institutional & Yes & & $\begin{array}{l}\text { Aused only once so far, for the foreign } \\
\text { tranche of a large offering }\end{array}$ \\
\hline Is it gaining popularity? & Too soon to tell & Already the only method used & Yes & & \\
\hline Whenjwas it first used? & & & $1997 / 1998$ & & $\wedge 2008$, for Safaricom \\
\hline * Tender/Auction & Yes - required for a decade & Not used & Yes & & \\
\hline Discriminatory/uniform & Uniform price, but two stages & & Discriminatory & & \\
\hline Hybrid Methods? & & $\begin{array}{l}\text { bb/public offer - only method in last few } \\
\text { years }\end{array}$ & $\begin{array}{l}\text { Yes - auction of } 50 \% \text { of shares; rest sold at } \\
\text { or below weighted average winning bid. } \\
\text { *Hybrids also for bookbuilding. }\end{array}$ & & $\begin{array}{l}\text { Yes - the one bookbuild still used fixed } \\
\text { price public offer for local investors }\end{array}$ \\
\hline General notes: & $\begin{array}{l}\text { Two stage auctions - Institutional auction } \\
\text { takes place } 24-48 \text { hours before publication } \\
\text { of prospectus. Winning inst'l orders } \\
\text { included in prospectus. Institutional } \\
\text { investors may not withdraw their bids, can } \\
\text { only offer HIGHER prices in public } \\
\text { auction. Public auction } 7 \text { days after } \\
\text { prospectus released. * From 1993-2003, } \\
\text { fixed price public offers banned, only } \\
\text { auctions allowed. Some auctions, some } \\
\text { fixed price public offers occurred in 2004- } \\
\text { 2007. BB first allowed in mid-2007. Few } \\
\text { IPOs in 2 years since BB allowed, due to } \\
\text { market conditions. }\end{array}$ & $\begin{array}{l}\text { Substantially more funds raised from sale } \\
\text { of existing shares than from new shares } \\
\text { for primary offers in general (this includes } \\
\text { privatizations and seasoned issues); public } \\
\text { offer tranche usually close to } 40 \% \text {, but the } \\
\text { size of each tranche can be adjusted based } \\
\text { on demand. Maximum price for public } \\
\text { offer set at least } 1 \text { day before the open of } \\
\text { the subscription period. }\end{array}$ & $\begin{array}{l}\text { Discriminatory hybrid auctions required } \\
\text { beg. 04/01/89: Retail tranche sold at } \\
\text { weighted average winning bid price. } \\
\text { Changes in } 1992 \text { required } \geq 50 \% \text { of shares } \\
\text { auctioned, allowed public offer price } \\
\text { weighted average winning bid (due to } \\
\text { perceived auction overpricing). Order size } \\
\text { restricted in retail tranches but not } \\
\text { auctions. } 1994 \text { Japan Tobacco IPO auction } \\
\text { raised US\$5.8 billion. When book } \\
\text { building allowed in 1997, auctions } \\
\text { disappeared within a quarter. } \\
\text { } \text { Commercial Code requires par value } \\
\text { backed by minimum of Y50,000 in assets. }\end{array}$ & $\begin{array}{l}\text { Offering price currently set by Issuing } \\
\text { Committee at Ministry of Industry and } \\
\text { Trade. This will soon change with the } \\
\text { introduction of private sector underwriters } \\
\text { to the market. The subscription period } \\
\text { will be determined in the near future by } \\
\text { the new regulations that regulate the new } \\
\text { issues that will be issued in accordance } \\
\text { with the Companies Law and the } \\
\text { Securities Law that was passed on May } \\
15,1997 \text {. }\end{array}$ & $\begin{array}{l}\text { Public Offer method: Investors pay in } \\
\text { advance, wait } 3 \text { weeks for refunds. } \\
\text { Interest on float goes to compensation } \\
\text { fund. Price set } 10 \text { days before } \\
\text { subscription period opens. Those who } \\
\text { apply for minimum number of shares } \\
\text { usually get them. Allocation is at the } \\
\text { issuer's discretion, but figures on intended } \\
\text { allocation must be furnished to Capital } \\
\text { Market Authority. BB tranche was } \\
\text { considered for KenGen in } 2006 \text { but too } \\
\text { controversial. Safaricom, } 2008 \text {, is only } \\
\text { Kenyan IPO with a bookbuilt tranche so } \\
\text { far. }\end{array}$ \\
\hline
\end{tabular}




\begin{tabular}{|c|c|c|c|c|c|}
\hline Country & Korea & Malaysia & Mexico & Netherlands & New Zealand \\
\hline Main sources: & 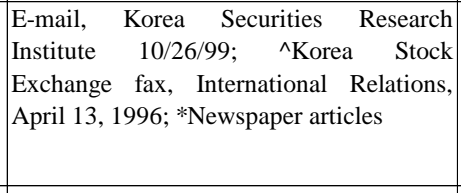 & 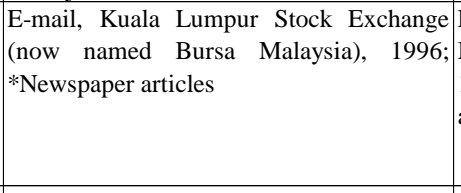 & $\begin{array}{l}\text { E-mail, Bolsa Mexicana de Valores (the } \\
\text { Mexican Stock Exchange), Sept.\& Nov. } \\
\text { 1999; www.bmv.com.mx; } \\
\text { articles }\end{array}$ & $\begin{array}{l}\text { E-mail, Stichting Toezicht Effectenverkeer } \\
\text { (SECURITIES BOARD OF THE } \\
\text { NETHERLANDS), Oct. 1999; }{ }^{\wedge} \text { "KPN's } \\
\text { Stock Won't Trade Until Completion of } \\
\text { IPO", Wall Street Journal Europe, } \\
\text { n//On/1994 }\end{array}$ & $\begin{array}{l}\text { E-mail 10/15/99 - Securities and } \\
\text { Exchange Commission of New Zealand; } \\
\text { www.gplegislation.co.nz; ^Fax - Cavill } \\
\text { White Securities Ltd., 21 May } 1996\end{array}$ \\
\hline Does gov't restrict method? & Yes & & & No & Yes \\
\hline Most common method & Hybrid Book Building & Hybrid Book Building & Public Offer & Hybrid Book Building & Hybrid Book Building \\
\hline * Public offer (Fixed price) & $\begin{array}{l}\text { Yes, in hybrids; Was only method until } \\
1998\end{array}$ & Yes - traditional method & Yes & becoming obsolete & $\begin{array}{l}\text { Yes - but brokers have allocational } \\
\text { discretion. }\end{array}$ \\
\hline Advance payment? & $\wedge$ Yes & Yes & & No & $\begin{array}{l}\text { Yes; installments getting popular. Legal } \\
\text { min. }=10 \% \text {. }\end{array}$ \\
\hline * Book Building & Yes - most common & *Yes - hybrid & ${ }^{\wedge}$ Yes, at least for international tranches & Yes & Yes \\
\hline Is it gaining popularity? & Yes & *Yes - it has become the main method & & Yes & Yes - last few years \\
\hline Whenjwas it first used? & $\begin{array}{l}\text { Required beg.1998 for KSE, } 1999 \text { for } \\
\text { KOSDAQ }\end{array}$ & & & "In recent years" & 1997 \\
\hline * Tender/Auction & Only if co. not listing on an exchange & Used for several large privatizations; & & Allowed & "Not applicable in practice" \\
\hline Discriminatory/uniform & & & & Discriminatory & Uniform price \\
\hline Hybrid Methods? & Yes, at least for privatizations & $\begin{array}{l}\text { Yes - both hybrid auctions and hybrid } \\
\text { bookbuilds; simultaneous }\end{array}$ & Yes - bb with public offer & Yes - bb with public offer & $\begin{array}{l}\text { Yes - bb for institutional, public offer for } \\
\text { retail at price set by bb }\end{array}$ \\
\hline General notes: & $\begin{array}{l}\text { There have been several dozen internet } \\
\text { Direct Public Offerings (DPOs), some of } \\
\text { which used auctions. Book building is } \\
\text { required if the co. wants to list on KSE or } \\
\text { KOSDAQ. *Korea until recently required } \\
\text { Public Offer, and the gov't set the offer } \\
\text { price until 1996. Recent Korea Gas Co. } \\
\text { privatization used public offer for retail, } \\
\text { max. order 4,000 shares, and bb for } \\
\text { institutional, with price set by bb. }\end{array}$ & $\begin{array}{l}\text { Some issuers must provide profit } \\
\text { guarantee (through bank guarantee) of at } \\
\text { least 90\% of forecast earnings for first 2-3 } \\
\text { years. Early 1990s: often long lines for } \\
\text { subscription forms. Mid-1990s: began } \\
\text { publishing forms in newspapers. 30\% of } \\
\text { IPO shares allocated to bumiputras (until } \\
\text { 2009). Securities Commission still } \\
\text { reserves right to review price setting. } \\
\text { Before 1/1/1996, the SC set price fairly } \\
\text { low, leading to high returns and low } \\
\text { application success rates (i.e. heavy } \\
\text { rationing) for IPOs. *Recent trend (2009) } \\
\text { is to attract foreign, particularly Chinese, } \\
\text { firms to list in on KLSE. }\end{array}$ & $\begin{array}{l}\text { IPO "has to be opened to all investors" } \\
\text { (except foreigners, who face industry- } \\
\text { based limits). ^Stock exchange officials } \\
\text { considered lowering listing requirements } \\
\text { in 2000, to encourage listings. } \\
\text { Regulations loosened in 2007, because } \\
\text { listings on the BMV had fallen from } 200 \text { a } \\
\text { decade earlier to only 133, with only } 4 \\
\text { IPOs in 2007. Many IPOs were cancelled } \\
\text { in 2008, and no companies had even } \\
\text { begun the process in the first half of } 2009 \text {. } \\
\text { Given the overall inactivity of the IPO } \\
\text { market, we cannot tell if bookbuilding is } \\
\text { likely to become popular. }\end{array}$ & $\begin{array}{l}\text { Book building is "almost standard practice } \\
\text { nowadays". The involvement of retail } \\
\text { investors in IPOs is high. AEX is } \\
\text { currently studying rules concerning the } \\
\text { distribution of shares. One of the proposed } \\
\text { new rules is the duty to disclose the } \\
\text { allotment of the offered securities. At } \\
\text { least in } 1994 \text { and before, book building } \\
\text { had to be completed and the final price set } \\
\text { before the opening of the public offer } \\
\text { subscription period. Almost all issuers } \\
\text { allowed grey market ("when issued") } \\
\text { trading prior to completion of their IPO. }\end{array}$ & $\begin{array}{l}\text { Public Offer method required by } \\
\text { Securities Act 1983, but many exceptions } \\
\text { have been made. The Securities } \\
\text { Commission is allowed to grant } \\
\text { exemptions \& has used this power on } \\
\text { several occasions since } 1997 \text { to permit } \\
\text { open pricing, including book building. } \\
\text { Book building used mainly for } \\
\text { institutional tranche of international } \\
\text { offerings but also for strictly local } \\
\text { offerings. For Public Offer, brokers have } \\
\text { discretion in terms of allocation; "public } \\
\text { pool" offerings are rare. }\end{array}$ \\
\hline
\end{tabular}




\begin{tabular}{|c|c|c|c|c|c|}
\hline Country & Norway & Pakistan & Paraguay & Peru & Portugal \\
\hline Main sources: & $\begin{array}{l}\text { E-mail - Banking, Insurance and Securities } \\
\text { Commission of Norway, Sep. 99; }{ }^{\wedge} \text { Letter - } \\
\text { Oslo Bors (Oslo Stock Exchange), } 14 \text { June } \\
1996\end{array}$ & $\begin{array}{l}\text { E-mail, Securities and Exchange } \\
\text { Commission of Pakistan, 12/01/99; }{ }^{\wedge} \text { web } \\
\text { page - Karachi Stock Exchange (Listing } \\
\text { regulations), updated } 30-05-1993 ;{ }^{*} \text { Media } \\
\text { search }\end{array}$ & $\begin{array}{l}\text { E-mail - Comision Nacional de Valores, } \\
\text { Oct 99; the Stock Exchange web page is } \\
\text { www.pla.net.py/bvpasa }\end{array}$ & E-mail - Lima Stock Exchange, 10/20/99 & $\begin{array}{l}\text { E-mail, Comissão do Mercado de Valores } \\
\text { Mobiliários (www.cmvm.pt), 11/11/99; } \\
\text { *Newspaper articles. }\end{array}$ \\
\hline Does gov't restrict method? & No & Yes & No & No & Used to, but since relaxed \\
\hline Most common method & Hybrid Book Building & Public Offer - only allowed method & Public Offer (only method used so far) & Hybrid Book Building & $\begin{array}{l}\text { Public Offer, often as a hybrid with Book } \\
\text { Building }\end{array}$ \\
\hline * Public offer (Fixed price) & $\begin{array}{l}\text { Yes, but rare except for retail tranche of } \\
\text { hybrid }\end{array}$ & Yes & & Yes & Yes - the most common \\
\hline Advance payment? & No, not usually & Yes & No & Sometimes, but not usually & Yes \\
\hline * Book Building & Yes -mainly for institutional. & No & Allowed, not used & Yes & Yes, hybrid with public offer tranche \\
\hline Is it gaining popularity? & Yes & & & Yes, particularly for institutional inv. & Yes \\
\hline When,was it first used? & increasingly popular over last few years. & & & & ^June '95 Portugal Telecom privatization \\
\hline * Tender/Auction & Yes, but "rarely used" & Only for privatizations to one buyer & Allowed, not used & Yes & "Very rare" now, but used in past \\
\hline Discriminatory/uniform & Uniform price & & & & Uniform price \\
\hline Hybrid Methods? & $\begin{array}{l}\text { Yes - bb for institutional and public offer } \\
\text { for local retail with price set by bb. }\end{array}$ & No & No & $\begin{array}{l}\text { Yes, particularly for privatizations - Book } \\
\text { Building/Public Offer }\end{array}$ & $\begin{array}{l}\text { Yes - bb for institutional, public offer for } \\
\text { retail }\end{array}$ \\
\hline General notes: & $\begin{array}{l}\text { No changes in regulations in last } 10 \text { years. } \\
\text { AThe main reason for the Public Offer } \\
\text { tranche is that companies need a certain \# } \\
\text { of shareholders, holding shares of at least } \\
\text { NOK } 5 \text { to } 10 \text { thousand, to list on the Oslo } \\
\text { Stock Exchange. Small investors } \\
\text { sometimes get their shares at a discount, } \\
\text { and occasionally they are favored in the } \\
\text { allocation process. }\end{array}$ & $\begin{array}{l}\text { Offer price was set by the government up } \\
\text { to June } 30,1995 \text {. ^May refund unused } \\
\text { subscription funds through direct depost } \\
\text { rather than mailing check. No company } \\
\text { listed unless public offer subscribed by at } \\
\text { least } 250 \text { applications. Prospectus } \\
\text { published at least } 7 \text { but no more than } 30 \\
\text { days before subscription period begins; } \\
\text { share certificates sent to successful orders } \\
\text { within } 30 \text { days of subscription close. }\end{array}$ & $\begin{array}{l}\text { Only fifty companies quote in the only } \\
\text { Stock Exchange, the Bolsa de Valores y } \\
\text { Productos de Asuncion S.A. (BVPASA), } \\
\text { most having opened their capital only } \\
\text { partially. Most shares were placed among } \\
\text { existing shareholders in virtue of the right } \\
\text { of preferential option. The first stock } \\
\text { negotiations in Paraguay took place in } \\
\text { October } 1993 \text { (market less than } 10 \text { years } \\
\text { old). }\end{array}$ & $\begin{array}{l}\text { Book building used mainly for } \\
\text { international transactions but sometimes } \\
\text { for local issues. Most Peruvian companies } \\
\text { are closed "family" companies. Therefore } \\
\text { raising capital is seldom done through an } \\
\text { IPO. Primary Public Offering Regulation, } \\
\text { modified on October 12, } 1998 \text { considers } \\
\text { that primary offers should be carried out } \\
\text { through an exchange floor, to provide } \\
\text { issues with a more transparent and } \\
\text { regulated framework as well as to attract } \\
\text { local and foreign investors. }\end{array}$ & $\begin{array}{l}\text { Bookbuilding first used for instutional } \\
\text { tranches of privatizations, but became } \\
\text { popular for private company IPOs as well. } \\
\text { Auctions popular for IPOs in the } 1980 \mathrm{~s} \\
\text { but 'very rare' in the } 1990 \text { s. *No private } \\
\text { Portugese company chose an auction after } \\
1988 \text {, but the government still used } \\
\text { auctions for privatizations until the } \\
\text { insurance company Mundial Confianca's } \\
\text { April } 1992 \text { tender left } 34.6 \% \text { of shares } \\
\text { unsold. }\end{array}$ \\
\hline
\end{tabular}




\begin{tabular}{|c|c|c|c|c|c|}
\hline Country & Singapore & South Africa & Spain & Sri Lanka & Sweden \\
\hline Main sources: & $\begin{array}{l}\text { E-mail - Stock Exchange of Singapore, } \\
10 / 11 / 99 ; \text { also the SES web page } \\
\text { (www.ses.com.sg) }\end{array}$ & $\begin{array}{l}\text { Web page and e-mail - Johannesburg } \\
\text { Stock Exchange, 10/99; www.jse.co.za } \\
\text { "Newspaper articles }\end{array}$ & 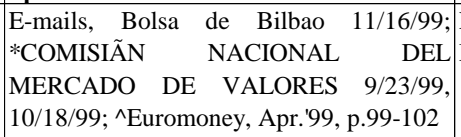 & $\begin{array}{l}\text { Letter - Colombo Stock Exchange, } 26 \\
\text { May, } 1997\end{array}$ & 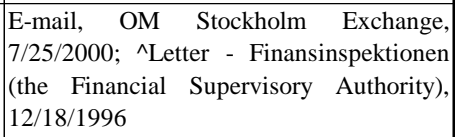 \\
\hline Does gov't restrict method? & Yes & Yes & *No & No & No \\
\hline Most common method & Hybrid Book Building & Hybrid Placing (similar to Book Building) & Hybrid Book Building & Public Offer & Hybrid Book Building \\
\hline * Public offer (Fixed price) & Yes -traditional & $\begin{array}{l}\text { Yes, but not popular except as part of } \\
\text { hybrid }\end{array}$ & Yes - retail tranche & Yes - only commonly used method & Yes \\
\hline Advance payment? & Yes; sometimes a fixed fee instead & Yes & No; deposits sometimes required & Yes & $\begin{array}{l}\text { Yes, usually "a couple of days" before } \\
\text { delivery }\end{array}$ \\
\hline * Book Building & Yes & $\begin{array}{l}\text { Placing - similar to bb in allocations but } \\
\text { price set in advance }\end{array}$ & Yes - institutional \& sometimes 100\% & Allowed, not widely used & Yes, for institutional tranche \\
\hline Is it gaining popularity? & Yes & & Yes & & Yes \\
\hline Whengुwas it first used? & $\begin{array}{l}\text { 1st - 1995, 2nd - 1999; Officially allowed } \\
\text { since March } 2000\end{array}$ & & & & \\
\hline * Tender/Auction & Allowed; not used since 1994. & No & *Allowed, "not habitually used" & Allowed, not widely used & Not used \\
\hline Discriminatory/uniform & Uniform price & & & & \\
\hline Hybrid Methods? & $\begin{array}{l}\text { Yes - simultaneous hybrids for both } \\
\text { auctions and bookbuilds }\end{array}$ & Yes - placing and public offer. & Yes - bb/public offer & & Yes - bb/public offer \\
\hline General notes: & $\begin{array}{l}\text { First } 2 \text { auctions, in '91, '92, were } \\
\text { discriminatory. Fund managers disliked } \\
\text { them, suggested single price, which was } \\
\text { used from ' } 93 \text { on. } 12 \text { of } 21 \text { IPOs in ' } 93 \text { and } \\
11 \text { of } 33 \text { in '94 were auctions. No } \\
\text { auctions since. One bb in '95, 2nd in } \\
1999 \text {, a possible third one on the way. } \\
\text { Rest of the } 20 \text { IPOs in '95, } 21 \text { in ' } 96,37 \text { in } \\
\text { '97, } 21 \text { in '98, } 30 \text { thru Sept. '99 all public } \\
\text { offer. Electronic Share Application (ESA) } \\
\text { and electronic balloting since 1993. 96\% } \\
\text { of applications thru ESA in 1996, 99\% } \\
\text { since. }\end{array}$ & $\begin{array}{l}\text { For placing, } 30 \% \text { of the shares must be } \\
\text { offered to the sponsoring broker, who } \\
\text { must allocate a reasonable number to other } \\
\text { brokers (usually } 30 \% \text { of his allocation). } \\
\text { They arrange for private clients or } \\
\text { institutions to take up parcels of shares, } \\
\text { subject to a fee, to ensure sufficient spread } \\
\text { of shareholders. A third method, } \\
\text { introduction, is allowed for companies that } \\
\text { want to be listed but do not need to raise } \\
\text { capital. *Telkom privatization, 2003, was } \\
\text { first use of simultaneous (rather than } \\
\text { sequential) hybrid, i.e., first open pricing. }\end{array}$ & $\begin{array}{l}\text { More and more public offer orders are } \\
\text { becoming binding even before final price } \\
\text { is set. Sometimes discounts are offered } \\
\text { for orders placed before a certain date. } \\
\text { Shifting shares between retail \& } \\
\text { institutional tranches based on demand } \\
\text { must be foreseen in prospectus. ^Most } \\
\text { offerings have retail tranches that tend to } \\
\text { be heavily oversubscribed; private issues } \\
\text { sometimes don't bother to include } \\
\text { international institutional investors, } \\
\text { because local demand is strong. }\end{array}$ & & $\begin{array}{l}\text { Hybrids allow open pricing. However, "as } \\
\text { a protective measure for the retail investor, } \\
\text { a maximum price must be set in advance. } \\
\text { The maximum price is normally set above } \\
\text { the indicative price range." Privatizations } \\
\text { are rare but are usually large and thus use } \\
\text { book building. }\end{array}$ \\
\hline
\end{tabular}




\begin{tabular}{|c|c|c|c|c|c|}
\hline Country & Switzerland & Taiwan & Thailand & Turkey & United Kingdom \\
\hline Main sources: & $\begin{array}{l}\text { E-mail - - Switzerland Stock Exchange, } \\
\text { 11/24/99; ^Letter - Zurcher Borse (Zurich } \\
\text { Stock Exchange), } 4 \text { June } 1996\end{array}$ & $\begin{array}{l}\text { E-mail Chinese Securities Association, } \\
11 / 2 / 99 \text {; }{ }^{\wedge} \text { Chiang, Qian and Sherman } \\
(2009)\end{array}$ & $\begin{array}{l}\text { Letter - Securities and Exchange } \\
\text { Commission, 14 May 1996; ^Asiamoney, } \\
\text { Nov. 2000, "Ratchaburi brings back sweet } \\
\text { Thai memories" }\end{array}$ & $\begin{array}{l}\text { E-mail - Istanbul Stock Exchange } \\
\text { (intercrd@ imkb.gov.tr), March 1999; Fax, } \\
\text { Istanbul Stock Exchange, 17 June 1996 }\end{array}$ & $\begin{array}{l}\text { General sources; *Brennan and Franks } \\
\text { (1997); ^Levis (1990); Chambers (2007) }\end{array}$ \\
\hline Does gov't restrict method? & No & Yes & Yes & Yes & Yes, but three options \\
\hline Most common method & Book Building & Hybrid Book Building & 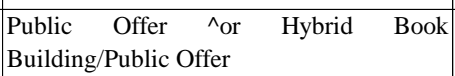 & Public Offer & $\begin{array}{l}\text { Public Offer (but book building for large, } \\
\text { international issues) }\end{array}$ \\
\hline * Public offer (Fixed price) & Yes - most common in 1980s & Yes; dominant for many years & Yes - most common & Yes - most common & Yes - most popular \\
\hline Advance payment? & No & No - only processing fee of NTD30 & Yes & $\wedge$ Yes & $\wedge$ Yes \\
\hline * Book Building & $\begin{array}{l}\text { Yes - 1st for large, internat'l IPOs, now for } \\
\text { domestic also }\end{array}$ & Hybrid w/ 50\% public offer & Yes - for large IPOs such as privatizations. & $\begin{array}{l}\text { Allowed; became popular in the late } \\
\text { 1990s; first used in } 1997\end{array}$ & *Placing - similar in terms of allocation \\
\hline Is it gaining popularity? & Yes & Yes & ${ }^{\wedge}$ Yes, as market recovers from Asia crisis & No & \\
\hline Whepwas it first used? & $\begin{array}{l}\text { Became popular "in last } 4 \text { years" (i.e., } \\
\text { since around 1995) }\end{array}$ & 2004 & & & \\
\hline * Tender/Auction & Allowed - not used in 1990s & Hybrid w/ 50\% public offer; previously & & Allowed; popular in 1994-1995, then & Allowed, not popular \\
\hline Discriminatory/uniform & & Discriminatory & & ${ }^{\wedge}$ Uniform price & Uniform price, Discriminatory \\
\hline Hybrid Methods? & Yes - bb/public offer & Yes - auction or bb with public offer & $\begin{array}{l}\text { Yes - book building with public offer; } \\
\text { } \text { price set by bb before open of } \\
\text { subscription period }\end{array}$ & Yes - bb/public offer & $\begin{array}{l}\text { Yes, although many bookbuilds do not } \\
\text { have a retail tranche }\end{array}$ \\
\hline General notes: & $\begin{array}{l}\text { Most recent privatization was Swisscom } \\
\text { (national telecommunications enterprice) } \\
\text { in } 1998 \text {, which used book building. ^The } \\
\text { tender method was used in a few cases, } \\
\text { during the boom phase of the late } 80 \text { 's, but } \\
\text { with little success }\end{array}$ & $\begin{array}{l}\text { Regulatory restrictions limited use of book } \\
\text { building for many years. ^Auctions were } \\
\text { popular for several years but were } \\
\text { abandoned for fixed price public offers. In } \\
\text { 2004, bookbuilding became popular and } \\
\text { seems to have replaced fixed price public } \\
\text { offers. From 1995-2007, there were: } 90 \\
\text { auctions from 1995-2003, with } 92 \% \text { of } \\
\text { these from 1996-2000; 156 bookbuilds } \\
\text { from 2004-2007; and 755 fixed price } \\
\text { public offers from 1995-2006. Multiple } \\
\text { bids allowed but total bids < } 3 \% \text { of shares } \\
\text { sold. Orders non-binding. }\end{array}$ & $\begin{array}{l}\text { Allotment to company's supporters cannot } \\
\text { exceed 10\% of total. At least } 30 \% \text { of IPO } \\
\text { shares must be allotted to public for } \\
\text { subscription, unless allotted portion not } \\
\text { fully subscribed. Allotments of top } 20 \\
\text { corporate or individual subscribers must } \\
\text { be publicly disclosed. ^ Price for hybrids } \\
\text { set by book building BEFORE the Public } \\
\text { Offer subscription period begins. }\end{array}$ & $\begin{array}{l}\text { Auctions popular for two years: } 18 \text { of } 24 \\
\text { IPOs in '94 \& } 7 \text { of } 29 \text { in '95 used BB, but } \\
\text { none of the } 17,27 \text { or } 20 \text { IPOs in '96, '97 or } \\
\text { '98 respectively used BB (except perhaps } \\
\text { Taç Yatirim Ortakligi A,S,, listed w/ IPO } \\
\text { date in '95, 1st trading date in '98). The } \\
\text { rest of the IPOs in these years were Fixed } \\
\text { Price Public Offers except for a few (6 in } \\
\text { '95, } 3 \text { in '96 and } 1 \text { in '98) using Sales on } \\
\text { the Exchange. ^Issuer must set binding } \\
\text { price margin (range) during registration \& } \\
\text { inform Capital Markets Board (CMB) } \\
\text { about final price (w/in margin) } 3 \text { days } \\
\text { before IPO. }\end{array}$ & $\begin{array}{l}\text { Auctions had periods of heavy use in } \\
\text { 1960s \& 1983-84. Last auction, for BAA } \\
\text { PLC in July 1987, was a discriminatory } \\
\text { hybrid that raised US\$1.98 billion.. *Of } 69 \\
\text { IPOs in 1986-89, 64 were Public Offer, } 4 \\
\text { tenders (auctions) and } 1 \text { hybrid } \\
\text { tender/public offer. ^Before Big Bang on } \\
\text { 27 Oct. 1986, placings not allowed for } \\
\text { issues over GBP } 3 \mathrm{mn} \text {. Auctions were } \\
\text { used in the UK from } 1960 \text { to } 1986 \text {, but } \\
\text { accounted for only } 8 \% \text { of all IPOs in that } \\
\text { time, while fixed price public offer was } \\
\text { the most popular method in those years. }\end{array}$ \\
\hline
\end{tabular}




\begin{tabular}{|c|c|c|}
\hline Country & United States & Vietnam \\
\hline Main sources: & $\begin{array}{l}\text { Prospectuses for specific offerings from the US SEC (Securities and Exchange } \\
\text { Commission) Edgar website. }\end{array}$ & $\begin{array}{l}\text { HoChiMinh Stock Exchange (HOSE) } \\
\text { website, www.hsx.vn; ^ } \\
\text { sources }\end{array}$ \\
\hline Does gov't restrict method? & No & Yes \\
\hline Most common method & Book Building & Auction \\
\hline * Public offer (Fixed price) & No & No \\
\hline \multicolumn{3}{|l|}{ Advance payment? } \\
\hline * Book Building & Yes & No \\
\hline Is it gaining popularity? & Already dominant & \\
\hline \multicolumn{3}{|l|}{ Whepwas it first used? } \\
\hline * Tender/Auction & Yes - 22 IPO auctions from 1999-2009 & Yes \\
\hline Discriminatory/uniform & Uniform price & Discriminatory \\
\hline Hybrid Methods? & $\begin{array}{l}\text { Not yet; the need to reconfirm orders once the final price is set would complicate the } \\
\text { process but could be worked out, as it has with auctions }\end{array}$ & \\
\hline General notes: & $\begin{array}{l}2 \text { main methods, firm commitment (book building) and best efforts. Book building } \\
\text { more common, used for larger issues. } 22 \text { uniform price IPO auctions so far (1999- } \\
\text { 2012). } 19 \text { of the auctions used WR Hambrecht's OpenIPO method, while three - } \\
\text { Netsuite, Rackspace, and popular search engine company Google - used auctions not } \\
\text { lead-managed by WR Hambrecht, with some different features. All auction issuers } \\
\text { so far have reserved the right to use a "dirty" auction (priced below market-clearing), } \\
\text { but transparency is lower in the US, so the market-clearing price often is not } \\
\text { revealed. Instinet used a hybrid book building/auction in May, 2001. A unique } \\
\text { feature of US auctions lead-managed by WR Hambrecht is that many issuers have } \\
\text { reserved the right to relay information on bidding trends to certain investors during } \\
\text { bidding, leading to clustering of institutional bids. Such leakage of order information } \\
\text { is usually illegal in non-US auctions but is common in book building around the } \\
\text { world. }\end{array}$ & $\begin{array}{l}\text { Auctions began in 2005; were "open" (all } \\
\text { bidders in the same room) until May, } \\
2007 \text {. For 1st "silent" (sealed bid) } \\
\text { auction for Bao Viet (Vietnam Insurance), } \\
\text { May 2007, 30\% of bidders forfeited } 10 \% \\
\text { deposits rather than pay remainder for } \\
\text { their winning bids, after seeing auction } \\
\text { results. Vietcom Bank's Dec. } 2007 \text { auction } \\
25 \% \text { oversubscribed at reserve price but } \\
\text { only } 90 \% \text { of shares later paid for. Potential } \\
\text { bidders pay deposit a few days before } \\
\text { auction, and number is announced. Shares } \\
\text { trade only OTC for months before official } \\
\text { listing. }\end{array}$ \\
\hline
\end{tabular}




\section{References}

Amihud, Y., Hauser, S., Kirsh, A., 2003. Allocations, adverse selection, and cascades in IPOs: Evidence from the Tel Aviv Stock Exchange. Journal of Financial Economics 68, 137-158.

Ausubel, L., 2002. Implications of Auction Theory for New Issues Markets. Brookings-Wharton Papers on Financial Services , $313-343$.

Benveniste, L., Spindt, P., 1989. How investment bankers determine the offer price and allocation of new issues. Journal of Financial Economics 24, 343-361.

Benveniste, L., Wilhelm, W., 1990. A comparative analysis of IPO proceeds under alternative regulatory environments. Journal of Financial Economics 28, 173-207.

Biais, B., Bossaerts, P., Rochet, J., 2002. An Optimal IPO Mechanism. The Review of Economic Studies 69, $117-146$.

Biais, B., Faugeron-Crouzet, A., 2002. IPO Auctions: English, Dutch, French, and Internet. Journal of Financial Intermediation 11, 9-36.

Booth, J., Chua, L., 1996. Ownership dispersion, costly information, and IPO underpricing. Journal of Financial Economics 41, $291-310$.

Bortolotti, B., Megginson, W., Smart, S., 2006. The Rise of Accelerated Seasoned Equity Underwritings. University of Oklahoma.

Bubna, A., Prabhala, N., 2009. When bookbuilding meets IPOs. Working paper, University of Maryland.

Busaba, W., Chang, C., 2003. Bookbuilding vs. Fixed Price Revisited: The Effect of Aftermarket Trading. University of Western Ontario.

Chahine, S., 2001. Mispricing in IPO Methods and the Predictive Ability of Investors' Interest for New Issues. Audencia-Nantes School of Management.

Charness, G., Levin, D., 2005. The Origin of the Winner's Curse: A Laboratory Study. Technical Report. University of California and Ohio State University.

Chemmanur, T., Liu, M., 2003. How Should a Firm Go Public? A Dynamic Model of the Choice Between Fixed-Price Offerings and Auctions in IPOs and Privatizations. Boston College.

Chemmanur, T.J., 1993. The pricing of initial public offerings - a dynamic-model with information production. Journal Of Finance 48, $285-304$.

Chiang, Y., Qian, Y., Sherman, A., 2009a. Endogenous entry and partial adjustment in IPO auctions: Are institutional investors better informed? Review of Financial Studies .

Chiang, Y.M., Hirshleifer, D.A., Qian, Y., Sherman, A.E., 2009b. Learning to fail? evidence from frequent ipo investors. Working paper.

Chowdhry, B., Sherman, A., 1996a. International differences in oversubscription and underpricing of IPOs. Journal of Corporate Finance 2, 359-381.

Chowdhry, B., Sherman, A., 1996b. The winner's curse and international methods of allocating initial public offerings. Pacific-Basin Finance Journal 4, 15-30.

Cliff, M., Denis, D., 2004. Do Initial Public Offering Firms Purchase Analyst Coverage with Underpricing? The Journal of Finance 59, $2871-2901$.

Cornelli, F., Goldreich, D., 2001. Bookbuilding and Strategic Allocation. The Journal of Finance 56, 2337-2369.

Cornelli, F., Goldreich, D., 2003. Bookbuilding: How Informative Is the Order Book? The Journal of Finance 58, $1415-1443$.

Cornelli, F., Goldreich, D., Ljungqvist, A., 2006. Investor Sentiment and Pre-IPO Markets. The Journal of Finance 61, 1187-1216.

Crawford, V., Iriberri, N., 2007. Level-k Auctions: Can a Nonequilibrium Model of Strategic Thinking Explain the Winner's Curse and Overbidding in Private-Value Auctions? Econometrica 75, 1721-1770.

Degeorge, F., Derrien, F., Womack, K., 2007. Analyst Hype in IPOs: Explaining the Popularity of Bookbuilding. Review of Financial Studies 20, 1021.

Degeorge, F., Derrien, F., Womack, K., Forthcoming. Auctioned ipos: the u.s. evidence. Review of Financial Studies .

Derrien, F., Womack, K., 2003. Auctions vs. Bookbuilding and the Control of Underpricing in Hot IPO Markets. Review of Financial Studies 16, 31-61.

Dyer, D., Kagel, J.H., Levin, D., 1989. A comparison of naive and experienced bidders in common value offer auctions - a laboratory analysis. Economic Journal 99, 108-115.

Eyster, E., Rabin, M., 2005. Cursed Equilibrium. Econometrica 73, 1623-1672.

Fleming, M., 2007. Who Buys US Treasury Securities at Auction. Current Issues in Economics and Finance 13, 1-7.

Fleming, M., Garbade, K., 2007. Dealer behavior in the specials market for US Treasury securities. Journal of Financial Intermediation 16, 204-228.

Fleming, M., Garbade, K., Keane, F., 2005. anomalous Bidding In Short-term Treasury Bill Auctions. The Journal of Financial Research 28, $165-176$.

Forsythe, G., Malcolm, M., Moler, C., 1977. Computer Methods for Mathematical Computations. Prentice Hall Professional Technical Reference. French, K., McCormick, R., 1984. Sealed Bids, Sunk Costs, and the Process of Competition. Journal of Business $57,417$.

Fritsch, F., Carlson, R., 1980. Monotone Piecewise Cubic Interpolation. SIAM Journal on Numerical Analysis 17, 238.

Garbade, K., 2004. The Institutionalization of Treasury Note and Bond Auctions, 1970-75. FRBNY Economic Policy Review 10, $29-45$.

Goldreich, D., 2007. Underpricing in Discriminatory and Uniform-Price Treasury Auctions. Journal of Financial and Quantitative Analysis 42, $443-466$.

Hameed, A., Lim, G., 1998. Underpricing and Firm Quality in Initial Public Offerings: Evidence from Singapore. Journal of Business Finance \& Accounting 25, 455-468.

Hamilton, L., 1992. Regression with graphics: A second course in applied statistics. Brooks/Cole Pacific Grove, CA.

Hausch, D., Li, L., 1993. A common value auction model with endogenous entry and information acquisition. Economic Theory 3, 315-334.

Hsu, Y., Hung, C., 2005. Why Have IPO Auctions Lost Market Share to Fixed-price Offers? Evidence from Taiwan. National Chengchi University.

Hsu, Y., Shiu, C., 2004. Information Content of Investors Bids in IPO Auctions: Evidence from Taiwan. Journal of Financial Studies 12, 27-50.

Jagannathan, R., Jirnyi, A., Sherman, A., 2010. Why Don't Issuers Choose IPO Auctions? The Complexity of Indirect Mechanisms. Technical Report. National Bureau of Economic Research.

Jagannathan, R., Sherman, A., 2005. Reforming the Bookbuilding Process for IPOs. Journal of Applied Corporate Finance 17, 67-72.

Jenkinson, T., Jones, H., 2004. Bids and Allocations in European IPO Bookbuilding. The Journal of Finance 59, 2309-2338.

Judd, K., 1998. Numerical Methods in Economics. MIT Press. 
Kagel, J.H., Levin, D., Harstad, R.M., 1995. Comparative static effects of number of bidders and public information on behavior in 2nd-price common value auctions. International Journal Of Game Theory 24, 293-319.

Kandel, S., Sarig, O., Wohl, A., 1999. The demand for stocks: an analysis of IPO auctions. Review of Financial Studies 12, $227-247$.

Kaufman, P.D. (Ed.), 2006. Poor Charlie Almanack: The Wit and Wisdom of Charles T. Maunger, PCA Publication LLC.

Kutsuna, K., Smith, R., 2004. Why Does Book Building Drive Out Auction Methods of IPO Issuance? Evidence from Japan. Review of Financial Studies 17, 1129-1166.

Lin, J., Lee, Y., Liu, Y., 2003. Why Have Auctions Been Losing Market Shares to Bookbuilding in IPO Markets? Indiana State University.

Liu, L., Sherman, A., Zhang, Y., 2009. The Role of the Media in Initial Public Offerings, in: AFA 2009 San Francisco Meetings Paper.

Liu, X., Ritter, J., 2011. Local underwriter oligopolies and ipo underpricing. Journal of Financial Economics 102, 579-601.

Liu, Y., Wei, K., Liaw, G., 2001. On the Demand Elasticity of Initial Public Offerings: An Analysis of Discriminatory Auctions. International Review of Finance 2, 151-178.

Ljungqvist, A., 2007. IPO Underpricing, in: Eckbo, B.E. (Ed.), Handbook of Corporate Finance: Empirical Corporate Finance. North Holland.

Ljungqvist, A., Jenkinson, T., Wilhelm, Jr, W., 2003. Global Integration in Primary Equity Markets: The Role of US Banks and US Investors. Review of Financial Studies 16, 63-99.

Loughran, T., Ritter, J., 2004. Why Has IPO Underpricing Changed Over Time? Financial Management 33, 5-37.

Loughran, T., Ritter, J., Rydqvist, K., 1994. Initial public offerings: International insights. Pacific-Basin Finance Journal 2, 165-199.

McKelvey, R., Palfrey, T., 1995. Quantal response equilibria for normal form games. Games and Economic Behavior 10, 6-38.

Milgrom, P.R., 1981. Rational-expectations, information acquisition, and competitive bidding. Econometrica 49, 921-943.

Mola, S., Rau, R., Khorana, A., Forthcoming. Is there life after the complete loss of analyst coverage? Accounting Review .

Myerson, R., 1981. Optimal auction design. Mathematics of operations research , 58-73.

Parlour, C.A., Rajan, U., 2005. Rationing in ipos. Review of Finance 9, 33-63.

Pesendorfer, W., Swinkels, J.M., 1997. The loser's curse and information aggregation in common value auctions. Econometrica 65, $1247-1281$.

Ritter, J., 2013. Re-energizing the ipo market, in: Bailey, M., Herring, R. (Eds.), Restructuring to Speed Economic Recovery. Brookings Press.

Ritter, J., Welch, I., 2002. A Review of IPO Activity, Pricing, and Allocations. The Journal of Finance 57, $1795-1828$.

Ritter, J.R., Forthcoming. Equilibrium in the IPO Market. Annual Review of Finance Economics .

Rock, K., 1986. Why new issues are underpriced. Journal of Financial Economics 15, 187-212.

Sherman, A., 1992. The Pricing of Best Efforts New Issues. Journal of Finance 47, 781-790.

Sherman, A., 2000. IPOs and long-term relationships: an advantage of book building. Review of Financial Studies 13, 697-714.

Sherman, A., Titman, S., 2002. Building the IPO order book: underpricing and participation limits with costly information. Journal of Financial Economics 65, 3-29.

Sherman, A.E., 2005. Global trends in ipo methods: Book building versus auctions with endogenous entry. Journal Of Financial Economics 78, 615-649.

Spatt, C., Srivastava, S., 1991. Preplay communication, participation restrictions, and efficiency in initial public offerings. Review of Financial Studies 4, 709-726.

Wilhelm, W., 2005. Bookbuidling, Auctions, and the Future of the IPO Process. Journal of Applied Corporate Finance 17, 55-66.

Yung, C., 2005. IPOs with Buy-and Sell-Side Information Production: The Dark Side of Open Sales. Review of Financial Studies $18,327-347$. 